\title{
The River and the Rocks
}

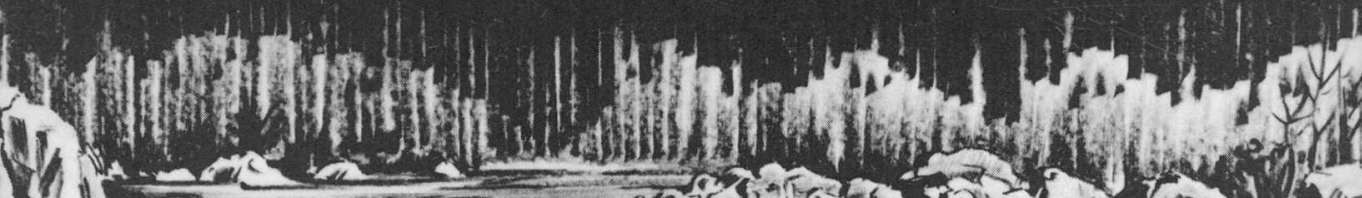

, iy.

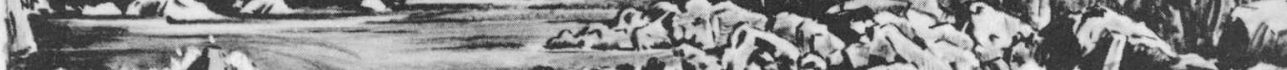

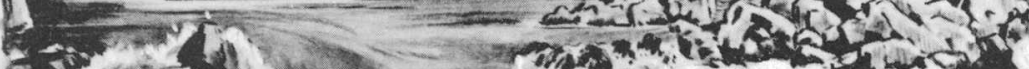
$x^{\prime}, 2$ e.

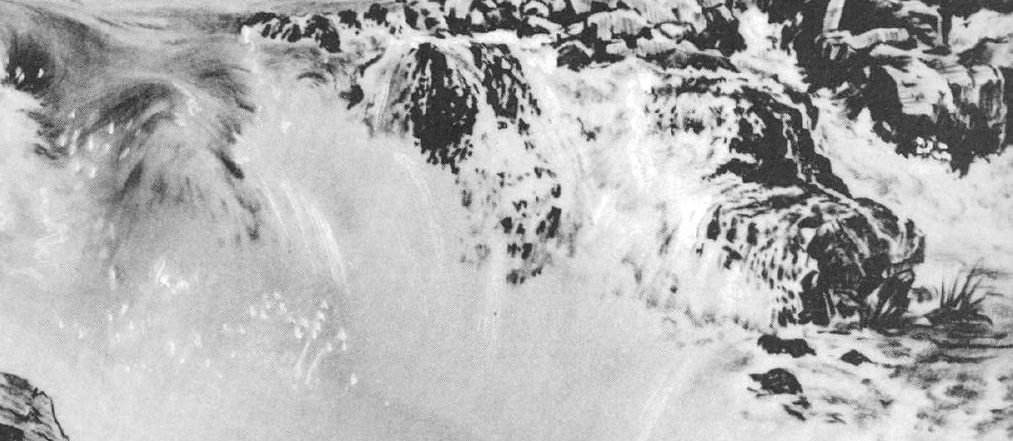

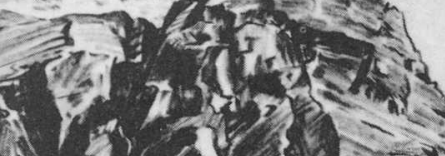

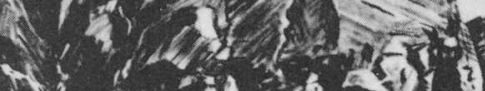
H. in 30.65 ? $-4=-15$ An $\therefore$ Tht

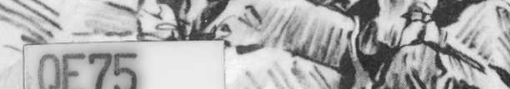

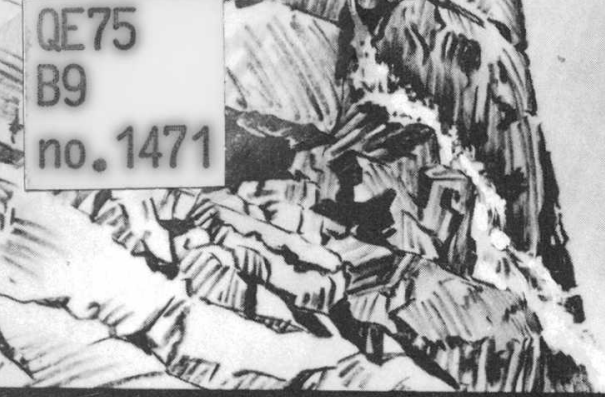

The Geologic Story of Great Falls and the Potomac River Gorge
Depository

R-SEIVED

MAR 201980

O.S.U. LIBRARIES 
OHIO STATE UNIVERSITY LIBRARIES 
The Geologic Story of Great Falls and the Potomac River Gorge 


\section{The River and th}

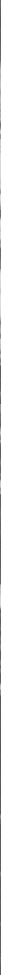




\section{ocks}

\section{The Geologic Story of Great Falls and the Potomac River Gorge}

BY JOHN C. REED, JR., ROBERT S. SIGAFOOS, AND GEORGE W. FISHER

U.S. Geological Survey Bulletin 1471 


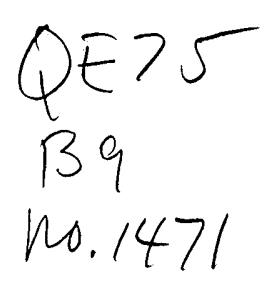

UNITED STATES DEPARTMENT OF THE INTERIOR

CECIL D. ANDRUS, Secretary

GEOLOGICAL SURVEY

H. William Menard, Director

Library of Congress catalog card No. 80-600023 Washington, D.C. 20402

Stock Number 024-001-03280-5 


\section{Foreword to the Second Edition}

The Great Falls of the Potomac River has figured prominently in the purposes of men since prehistoric time. Long before John Smith reached the falls in 1608 , groups of Indians from East and West met at this great river barrier to trade and perform ceremonies in honor of the spirit of the "Roaring Waters." As early as 1754, George Washington visualized the Potomac River as an important avenue of trade and communication with the interior.

Records show that, with the exception of Mount Vernon, Great Falls was perhaps as intimately associated with Ceorge Washington's everyday life as any other place in the country. As first President of the "Patowmac Canal Company," Washington frequently visited the working parties as they constructed the canal and lock system which skirted the treacherous falls on the Virginia side. Matildaville, a town of about 16 hectares named after the wife of "Light Horse" Harry Lee and consisting of various dwellings, grist mill, market house, forge, sawmill, and tavern, sprang up along the banks of the canal.

In 1802, the Patowmack Company canals were essentially completed, and hundreds of boats plied the river, bringing corn and wheat, coal and limestone, flaxseed, and furs downstream from the mountainous region around Cumberland. Many of the boats were sold for lumber in Ceorgetown, thus sparing the boatmen an arduous upstream journey.

After the establishment of the Nation's Capital, Great Falls became a popular scenic attraction for residents and visitors alike. But Creat Falls was not always as easily accessible as it is today. In 1845 , a newspaper columnist, after praising the beauty and historic interest of the region, added, ". . the access to this interesting spot is, on both sides of the river, by the most infamous roads and the accomodations for visitors anything but what they ought to be!"

Visitors to Great Falls now number more than one-half million annually and, because of this continuing and mounting interest, the U.S. Geological Survey has joined with the National Park Service in preparing this booklet for better understanding and enjoyment of the Great Falls of the Potomac River. The original edition was published in 1970. The current edition has been revised and expanded to incorporate new information, an enlarged trail log, and changes in trail locations. Because the policy of the Ceological Survey is to foster use of the International System of Units, all measurements in this edition are in the metric system.

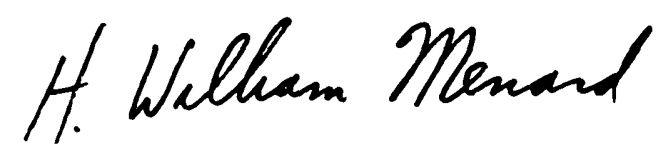




\section{Contents}

\section{v Foreword}

1 The falls today

3 The river and the land

8 The origin of the Potomac River valley and the carving of Great Falls

13 The origin of the rocks

20 A few words about the forests

24 Trail log-Great Falls, Virginia

49 Trail log-Great Falls, Maryland

74 Suggested reading

75 Acknowledgments

75 Metric-English conversion 


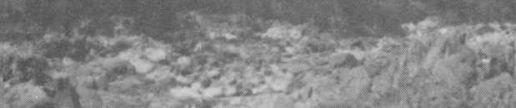

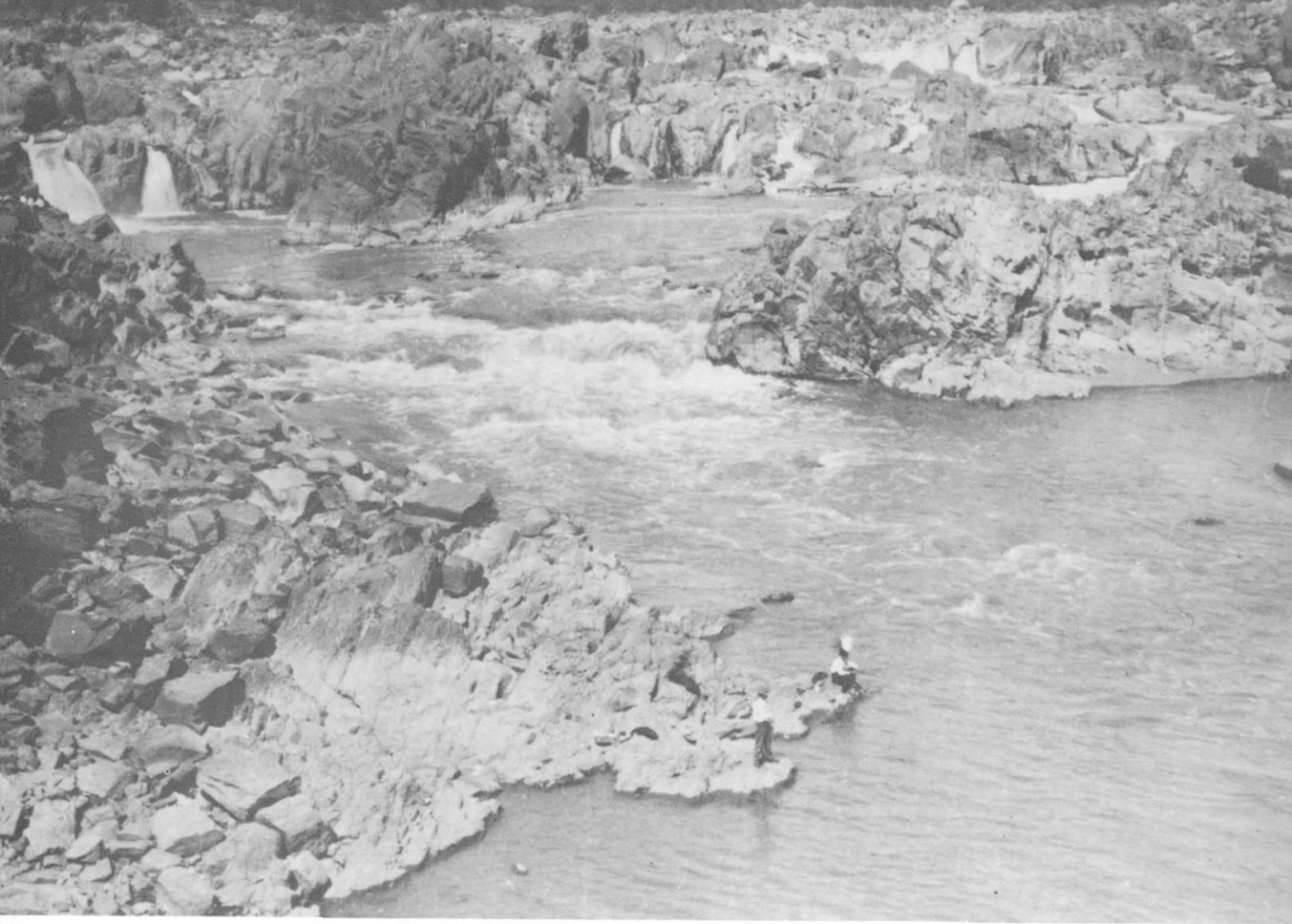
$x^{2}=$

\section{$\Delta$ Average flow stage in summer}

- Flow in flood stage

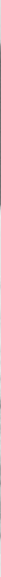




\section{The Falls Today}

The Great Falls of the Potomac River is the most spectacular landscape feature of the Washington metropolitan area. It has influenced the lives and fortunes of man in the Potomac Valley for centuries. Countless generations of Indians used it as a place to gather, to trade, and to fish. For the early settlers it was a barrier to river navigation, an obstacle that canal builders struggled to overcome. The river above the falls has been the principal source of water for the city of Washington for more than 100 years.

In its seaward course, the Potomac River crosses many small rapids and cascades, but these are insignificant in comparison with the foaming fury of Creat Falls, where the river drops 12 meters in about 180 meters and is channeled into a narrow rock-walled gorge less than 25 meters wide in places. In the summer the flow may be less than 38,000 liters a second, but during floods the flow commonly reaches 40 million liters a second. The average flow pouring over the falls is 349,000 liters of water every second and in a year, more than 9.5 trillion liters - enough water to flood the entire District of Columbia to a depth of 55 meters, converting the Washington Monument (169 meters high) into a tall lighthouse.

During three periods of recent flooding - in 1936, again in 1942, and still again in 1972 - water covered the towpath of the Chesapeake and Ohio ( $\mathrm{C}$ and $\mathrm{O}$ ) Canal on the Maryland side of the river and spread across the area of the Visitor Center and parking lots on the Virginia side. Floods of this size are unusual; but about once every 2 years, floodwaters rise to the brink of the gorge at the falls, reaching to within 4 to 6 meters of the trails and overlooks along the cliffs. There have been 20 such floods since 1930.

Today the Great Falls of the Potomac, the Mather Corge, and the surrounding scenic area administered by the National Park Service provide splendid opportunities for outdoor recreation. But perhaps most important of all, they serve as a unique outdoor laboratory for nature studies and a place to reflect on the impact of man on his natural environment.

Such studies require an understanding of the landscape - the geologic story concealed behind the scenery. This booklet presents a brief account of the geology of Great Falls, summarizing what is known of the events that formed the rocks and shaped the land. 


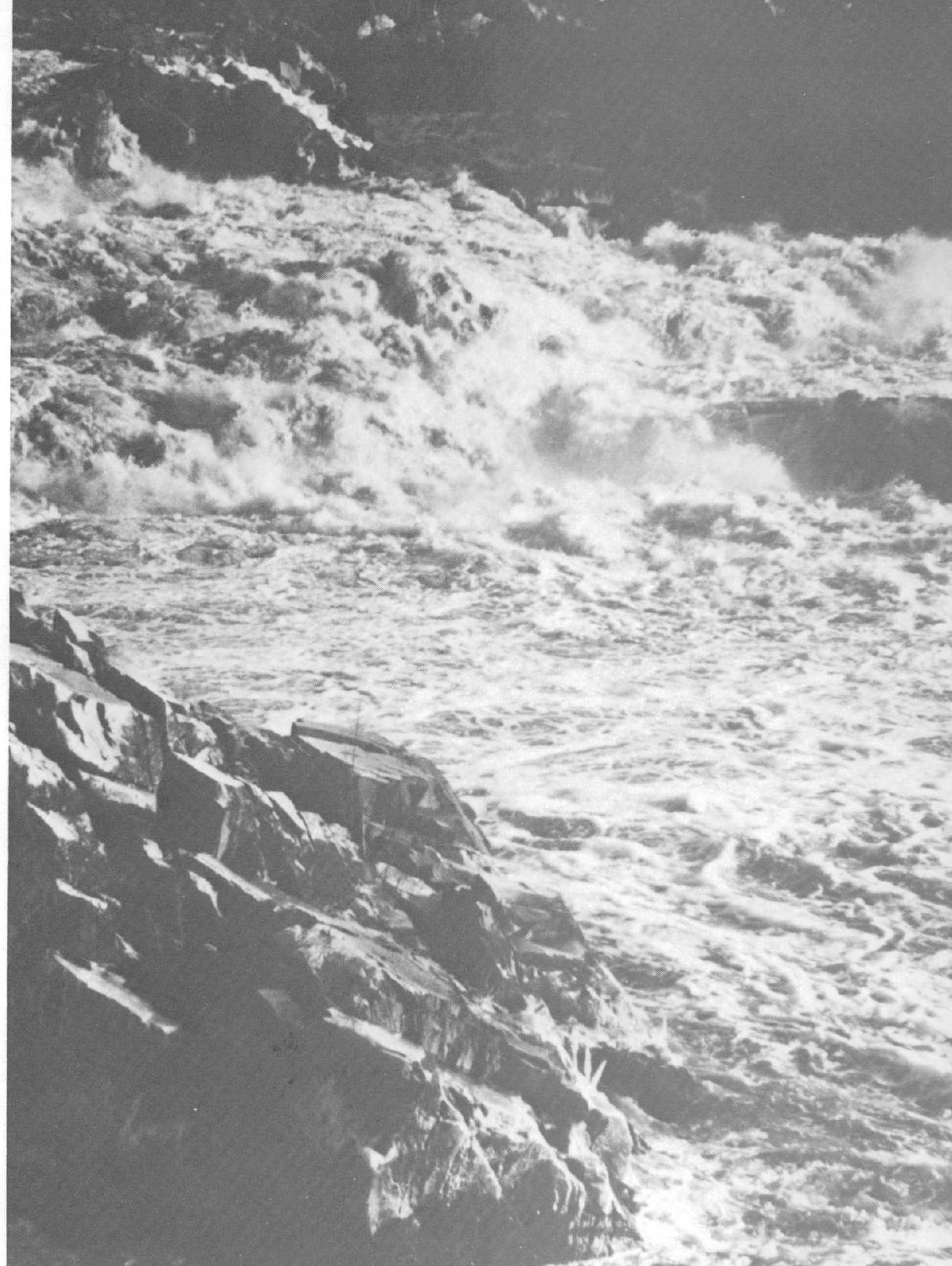

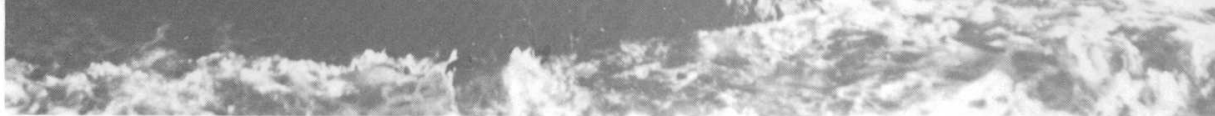




\section{The River and the Land}

All landscapes are the result of a continuing struggle between the deepseated earth forces that raise the land above sea level and the forces of erosion that gradually wear down the land surface. Erosion begins with the weathering of rocks - the chemical decay and solution of mineral grains and the mechanical disintegration of rocks by frost. The resulting debris is carried into streams and rivers by running water, again aided by frost action and the slow creep of soil down the slopes. Once in the streams the debris is transported seaward, partly in solution, partly as mud and silt in suspension, and partly as sand, gravel, and boulders rolled or bounced along the bottom. The Potomac River is estimated to carry more than 1.45 million metric tons of sediment and about 1 million metric tons of dissolved material over the falls each year. This amounts to 80 metric tons of material removed from each square kilometer of the river's drainage basin above the falls.

The Potomac, like other Atlantic seaboard rivers, rises in the Appalachian Mountains and flows eastward to the Atlantic Ocean. The river cuts through the Blue Ridge at a narrow gap below Harpers Ferry and across Catoctin Mountain, the easternmost ridge of the Appalachians, through a similar gap at Point of Rocks. From there to its mouth at Point Lookout on Chesapeake Bay, the river flows across three major landscape provinces: a broad lowland between Point of Rocks and Seneca that is called the Frederick Valley in Maryland and the Leesburg Basin in Virginia; the Piedmont Plateau, between Seneca and Washington; and the Atlantic Coastal Plain, between Washington and Point Lookout.

The nature of the landscape and river valley in each of these provinces is determined largely by the nature of the underlying rocks. The Frederick Valley and Leesburg Basin are underlain principally by red sandstone and shale that were deposited during the Triassic and Jurassic Periods, about 200 million years ago. Because these rocks are rather easily eroded, the land's surface is nearly flat; slopes are gentle and smooth. The river is wide, sluggish, and shallow, and is flanked by broad flats frequently covered by floodwaters.

The Piedmont Plateau is a rolling, hilly upland underlain by hard rocks. Although these rocks are very resistant to erosion, they are subject to chemical decay, which in places extends to depths of 30 meters or more 


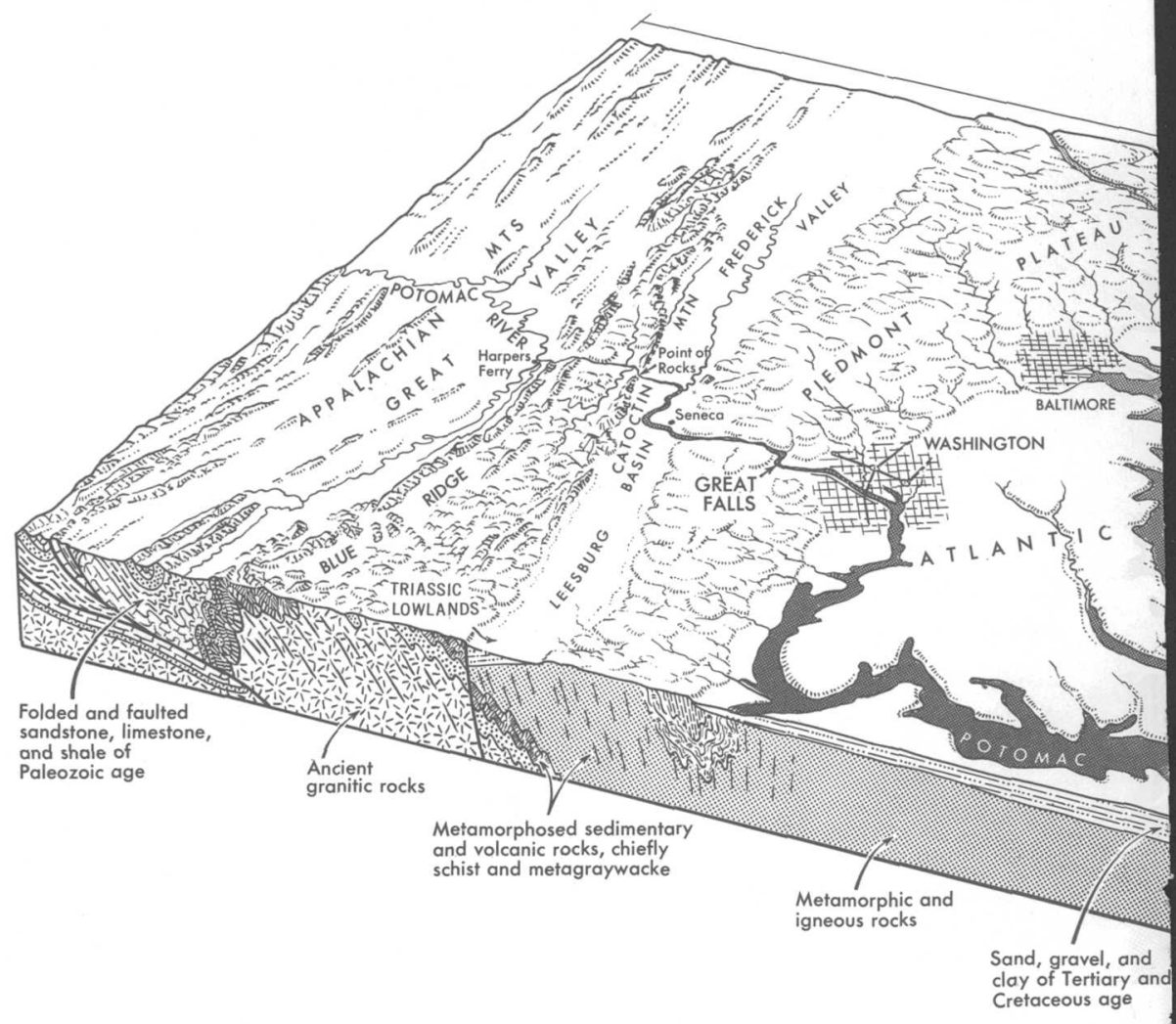

and produces saprolite (rotten rock) and deep, red clayey soils. The smaller streams on the uplands have not cut through the blanket of soil and soft decayed rock and thus flow in broad valleys and wide flood plains, but the larger streams have cut through to hard rocks and flow within narrow steep-sided valleys having constricted flood plains.

The nature of the valley of the Potomac across the Piedmont Plateau is quite variable. Above Great Falls the valley is steep sided but wide, and in most places the river is broad, shallow, and placid. In a few places, however, riffles and rapids break the quiet water as it passes across resistant ledges of rock. The numerous islands are composed of sand and gravel laid down by the river, and none of them rises much above the level of the flood that occurs about once every 2 years. At Great Falls the character of the river changes abruptly. From there to Theodore Roosevelt Island, it flows within a series of narrow rockgirded channels twisting between cliffs and flat-topped bedrock islands 


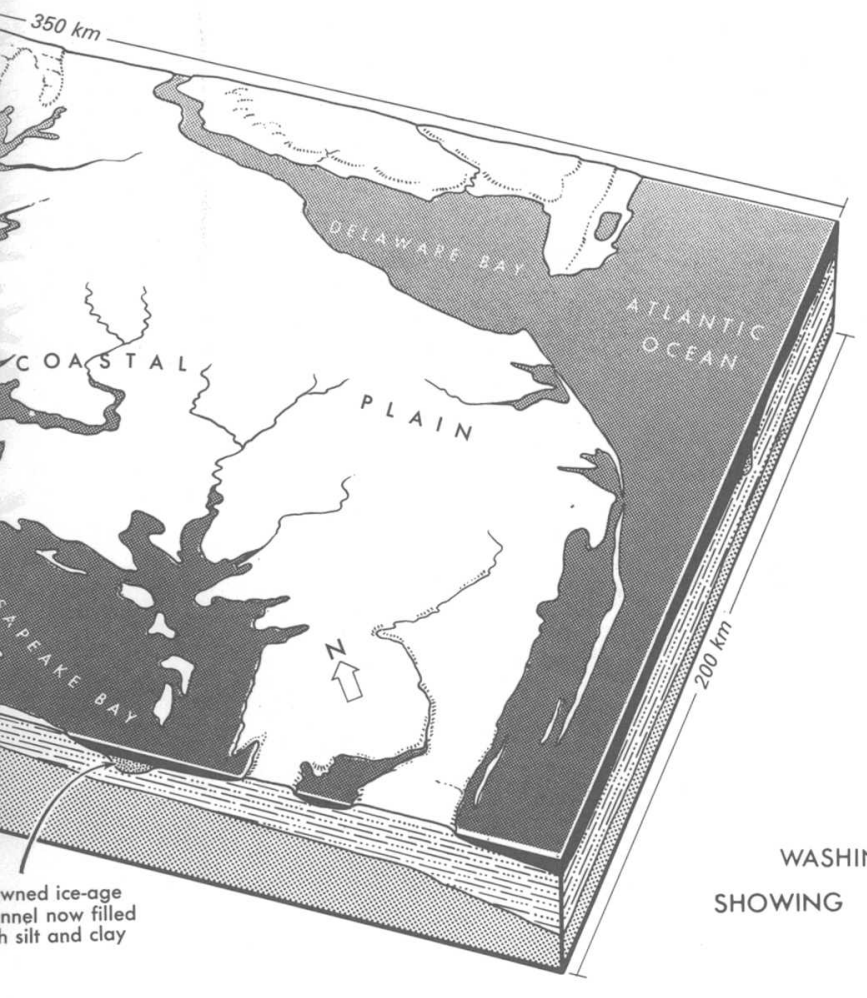

BLOCK DIAGRAM OF THE WASHINGTON-BALTIMORE REGION PHYSIOGRAPHIC PROVINCES AND GEOGRAPHIC AND GEOLOGIC FEATURES

that rise well above the level of the highest known floods. Passing over a series of rapids and low falls, including Yellow Falls, Stubblefield Falls, and Little Falls, the river reaches the level of the sea at Chain Bridge.

As the river flows beneath the Arlington Memorial Bridge, it leaves the Piedmont Plateau and enters the Atlantic Coastal Plain. The Coastal Plain is underlain by layered deposits of sand, clay, gravel, and shells laid down in and along the edge of the sea when it encroached onto the eastern edge of the continent at various times during the past 100 million years. In cross section, these deposits resemble a gigantic wedge ranging from thicknesses of a few meters near the inland edge to nearly 3,000 meters along the Maryland coast. Chesapeake Bay and its system of estuaries are ancient valleys cut in the soft sediments of the Coastal Plain when sea level stood much lower. When the sea rose to its present level, the valleys were flooded. The Potomac River occupies one of 


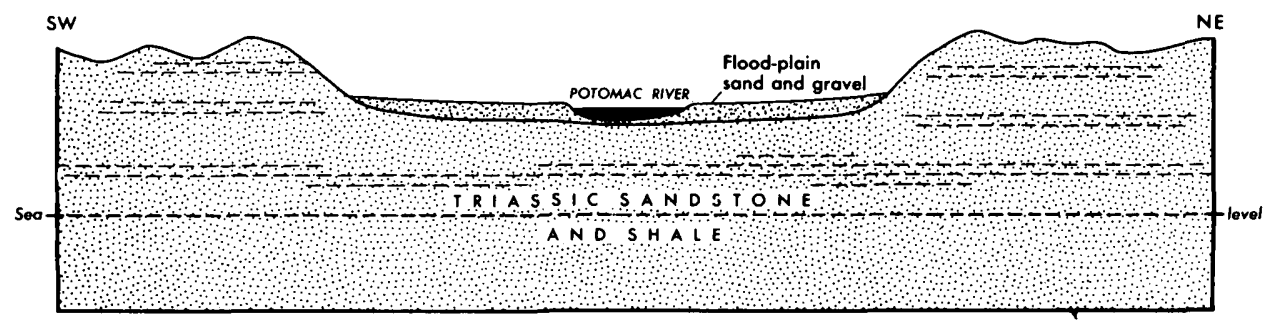

LEESBURG BASIN 15 KILOMETERS ABOVE GREAT FALLS NEAR SENECA
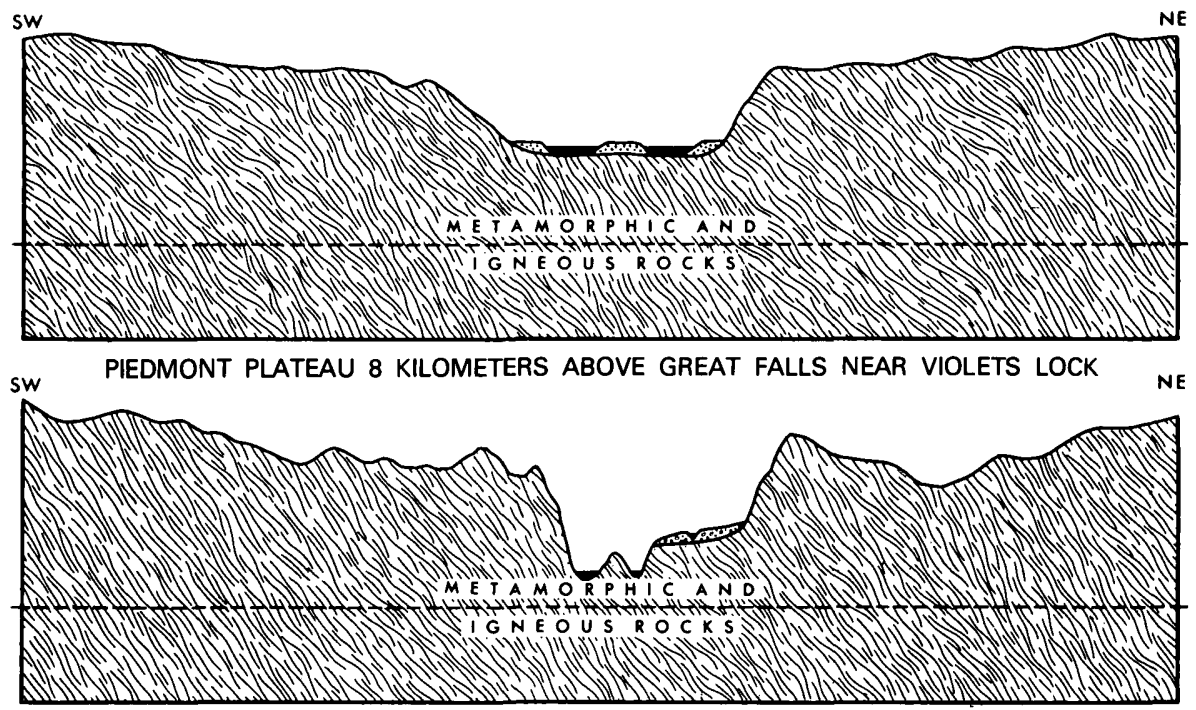

PIEDMONT PLATEAU 6 KILOMETERS BELOW GREAT FALLS NEAR CARDEROCK

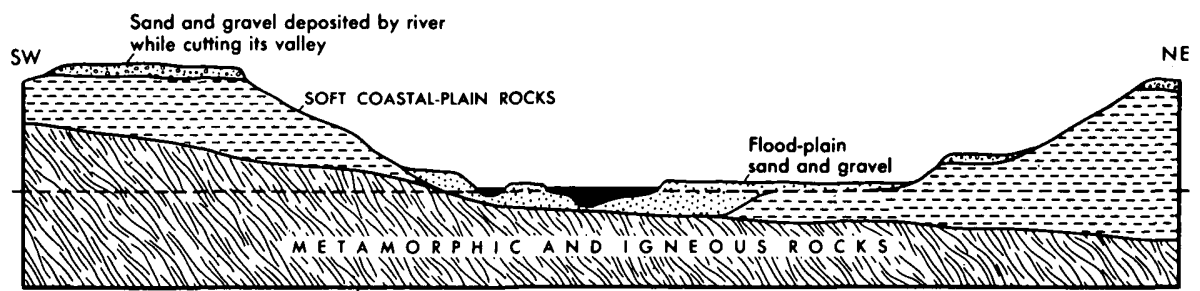

FALL LINE, ARLINGTON MEMORIAL BRIDGE

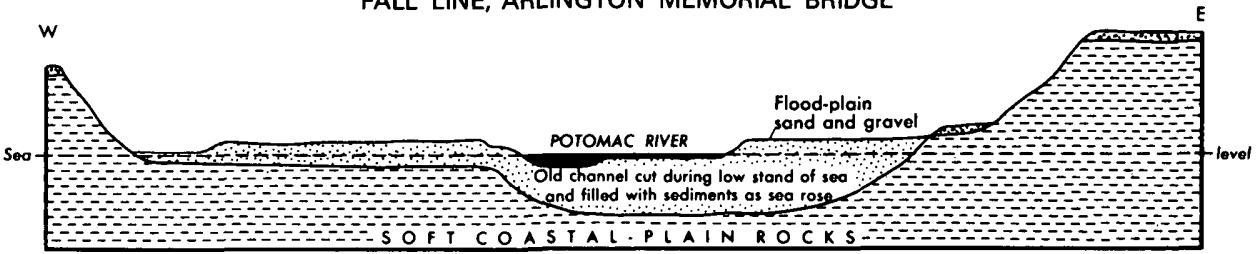

ATLANTIC COASTAL PLAIN, ALEXANDRIA, VIRGINIA

CROSS SECTIONS OF POTOMAC RIVER VALLEY SHOWING TYPICAL SHAPE IN EACH LANDSCAPE PROVINCE

Each cross section is approximately 6 kilometers long 
these "drowned" valleys between Washington and its mouth at Point Lookout. The broad river, here affected by tides and navigable by oceangoing ships, is flanked by wide low terraces and, in a few places, by wave-carved bluffs in the soft Coastal Plain rocks.

The boundary between the hard rocks of the Piedmont Plateau and the soft, easily eroded rocks of the Coastal Plain is called the Fall Line, because it is the line along which falls and rapids are first encountered in ascending the major rivers. It marks the head of navigation for oceangoing ships and the farthest point downstream that the streams can be crossed by fords or small bridges. For this reason, many of the cities of the eastern seaboard from Trenton, N.J., to Macon, Ca., were established along the Fall Line.

Although the nature of the river valley is largely controlled by the properties of the underlying rocks, these alone are not sufficient to explain the origin of the falls and the Potomac Corge. If they were, one would expect Great Falls to lie at the Fall Line, rather than 25 kilometers upstream in the middle of the Piedmont Plateau. The reason for the present location of Great Falls must be sought through studies of the geologic history of the Potomac River valley.

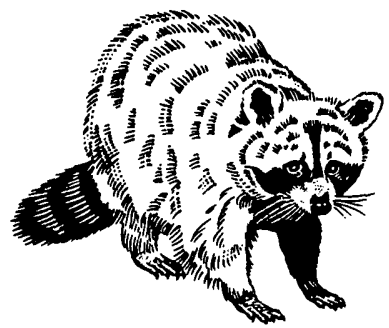




\section{The Origin of the Potomac River Valley and The Carving of Great Falls}

As the sea finally withdrew eastward from the Washington area between 6 and 7 million years ago, streams draining from the Appalachian Highlands spread a blanket of silt, sand, and gravel over the Coastal Plain deposits and nearby parts of the Piedmont Plateau. This blanket was not laid down by a single major river, but by numerous streams that constantly shifted their courses back and forth to form a complex series of coalescing fan-shaped deposits. Remnants of this blanket are still preserved capping some of the highest hills in the Piedmont near Tysons Corner, Va., 8 kilometers south of Great Falls.

Continued slow uplift of the Piedmont Plateau and the Appalachian Highlands to the west increased the slope of the land surface, causing the streams to deepen their valleys and eventually to combine into a river which was to become the Potomac. As this river deepened its valley, scattered remnants of its former flood plains were left at various levels as gravel-covered terraces. About 2 million years ago the river had carved a broad, open valley in approximately its present position.

With the beginning of continental glaciation in the Pleistocene Epoch-about 2 million years ago-sea level was lowered, and the Potomac River began deepening this early valley. As water was withdrawn from the oceans to form the great ice sheets on the land, sea level around the world fell by as much as 150 meters. Most of the continental shelf off the Eastern United States was exposed, and the shoreline lay as much as 120 kilometers east of its present position. Actually, continental glaciation occurred not just once, but at least four times in the last 2 million years. The last glacier advanced into central New Jersey as recently as 18,000 years ago, and glaciers disappeared from much of Canada only 12,000 years ago. 


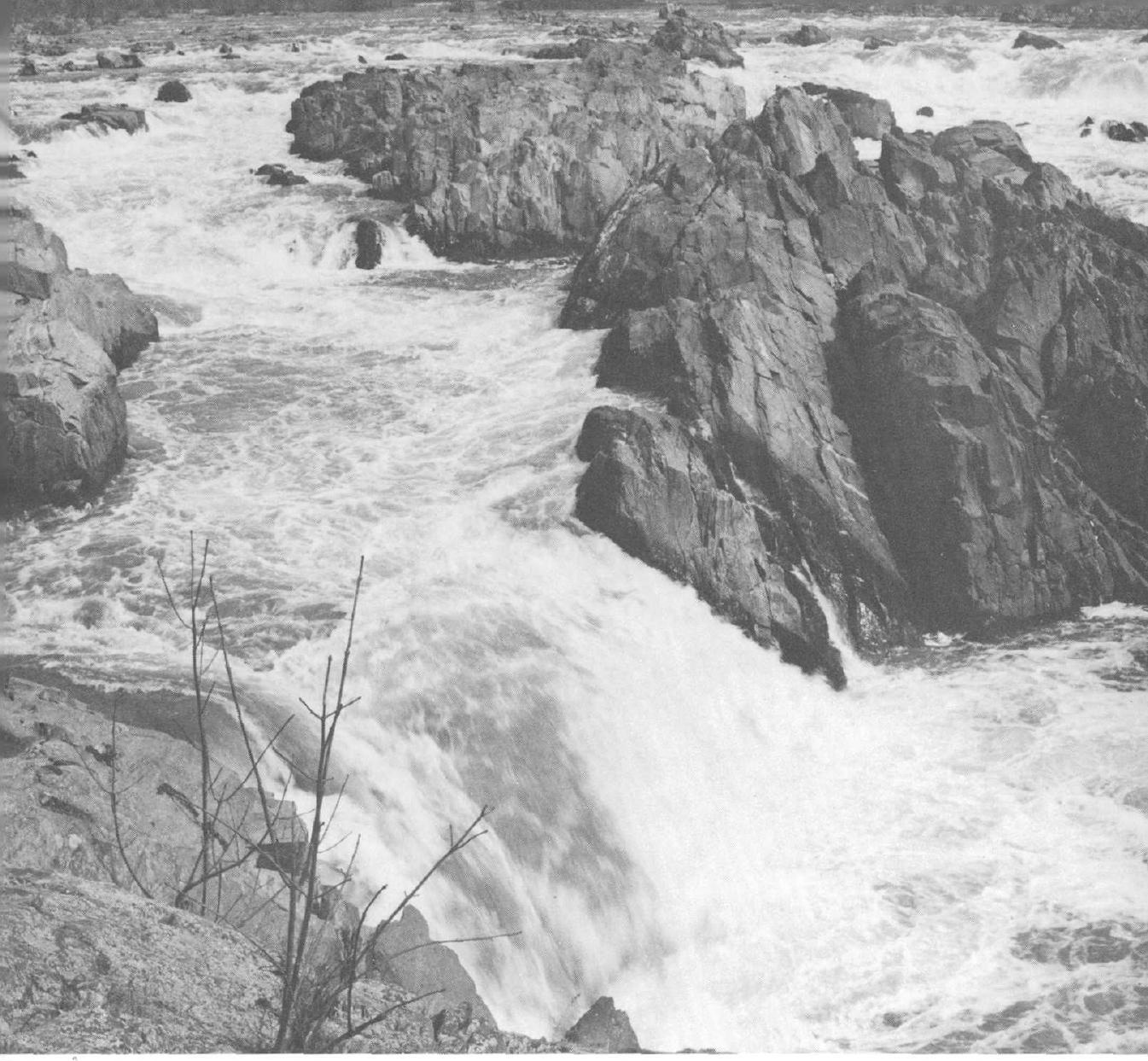

As sea level fell, the river cut correspondingly deeper into the floor of its former valley. The valley was rapidly deepened in the soft, easily eroded materials in the Coastal Plain, but in the hard rocks of the Piedmont Plateau the downcutting was much slower. It was this downcutting into the hard bedrock floor of the older wider valley that produced the spectacular rocky gorge of the Potomac between Little Falls and Great Falls. At Great Falls the river encounters a series of thick rock layers that are particularly resistant to erosion, and these hard ledges have slowed the progress of valley cutting. The river valley above Great Falls thus remains essentially the unmodified, original pre-Pleistocene valley, but below the falls the river flows in a gorge excavated within the last 2 million years. Along the gorge the original valley floor can be recognized as a flat gravel-covered bench 15 to 18 meters above the present river level. MacArthur Boulevard follows this bench from Cabin John to Anglers Inn. Some of the details of the cutting of the gorge and the sculpturing of Great Falls are illustrated in the block diagrams. 


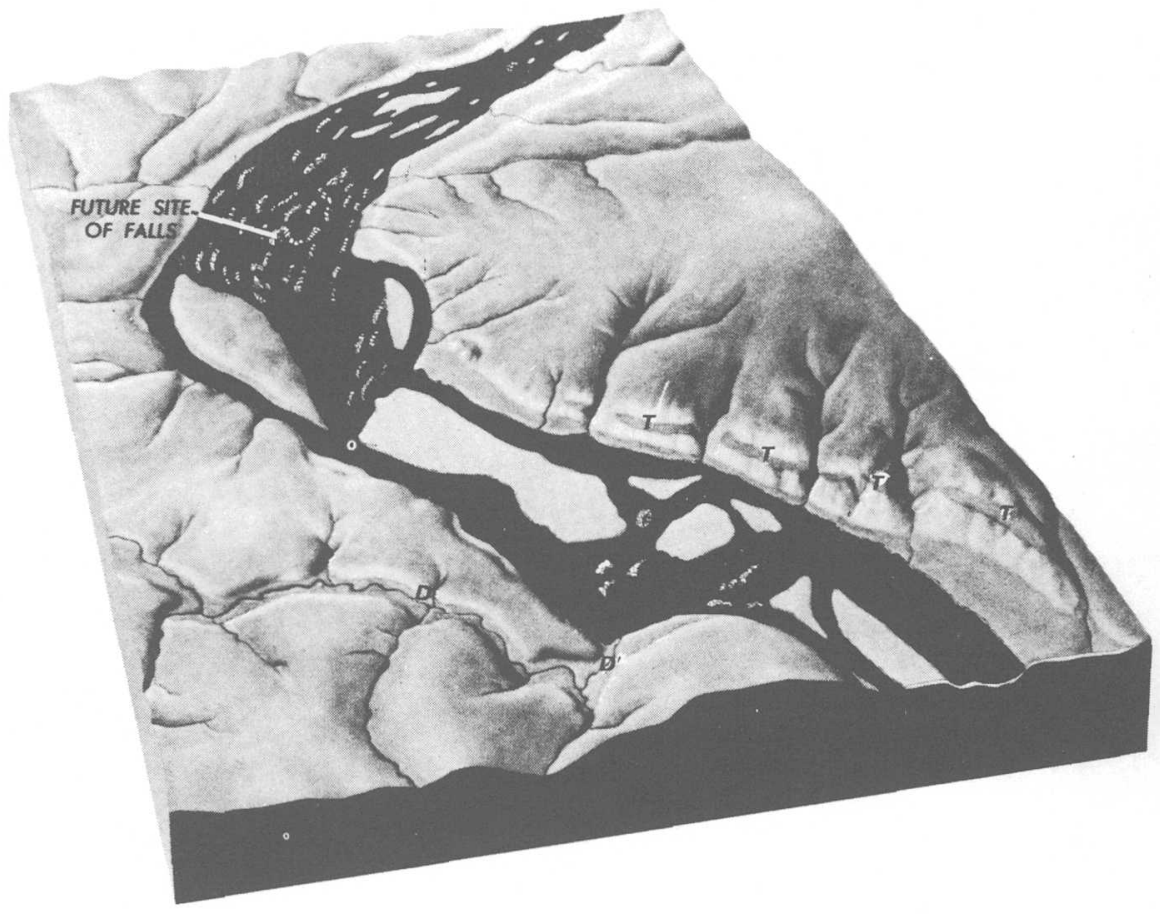

$\Delta$ A. The Great Falls area as it probably appeared before the Ice Age. The river occupies a broad valley, and the future site of the falls is marked by rapids and ledges of resistant rock. Gravel-covered benches $(T)$ are remnants of an older, higher valley floor. Difficult Run (D-D') flows across a broad, flat flood plain to empty into the Potomac River.

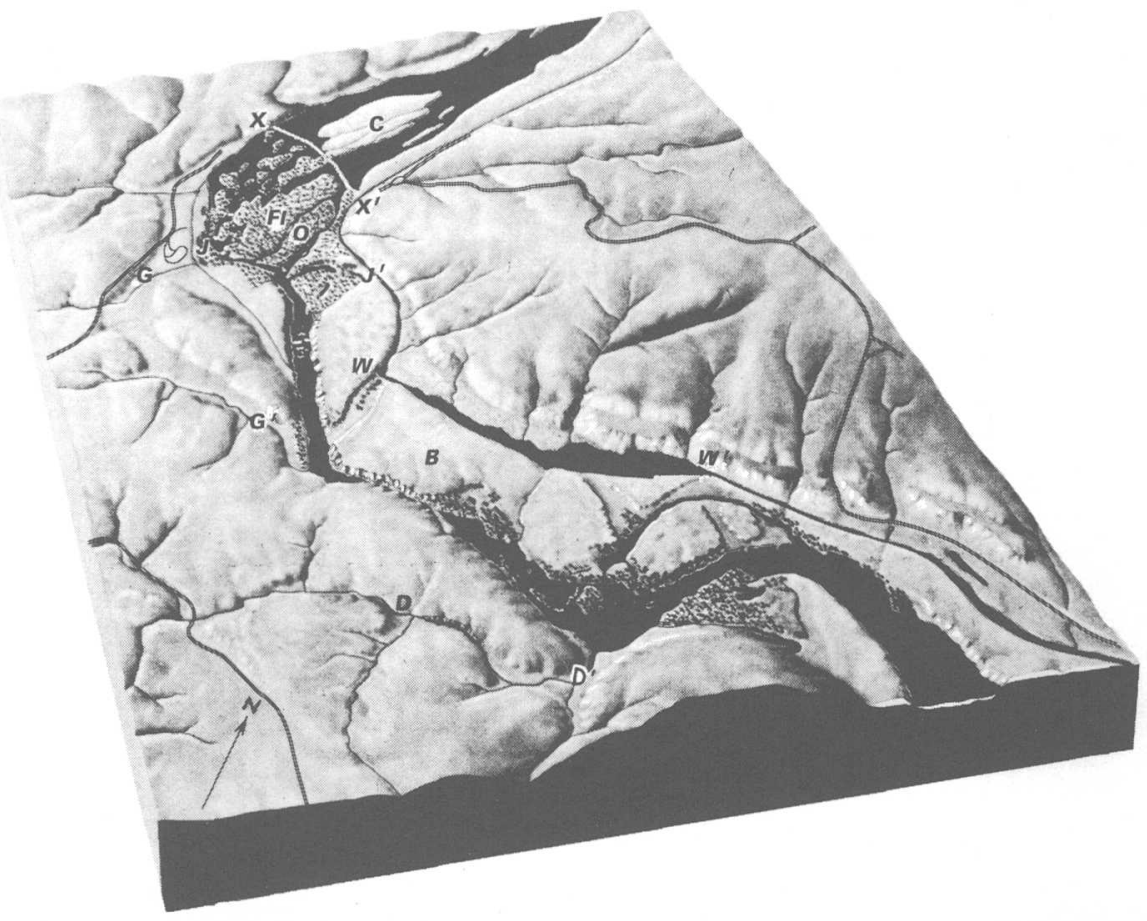


STAGES IN THE CARVING OF GREAT FALLS. The area of the block diagram covers about the same area as that shown on the map. Refer to the map for scale and names of geographic features.

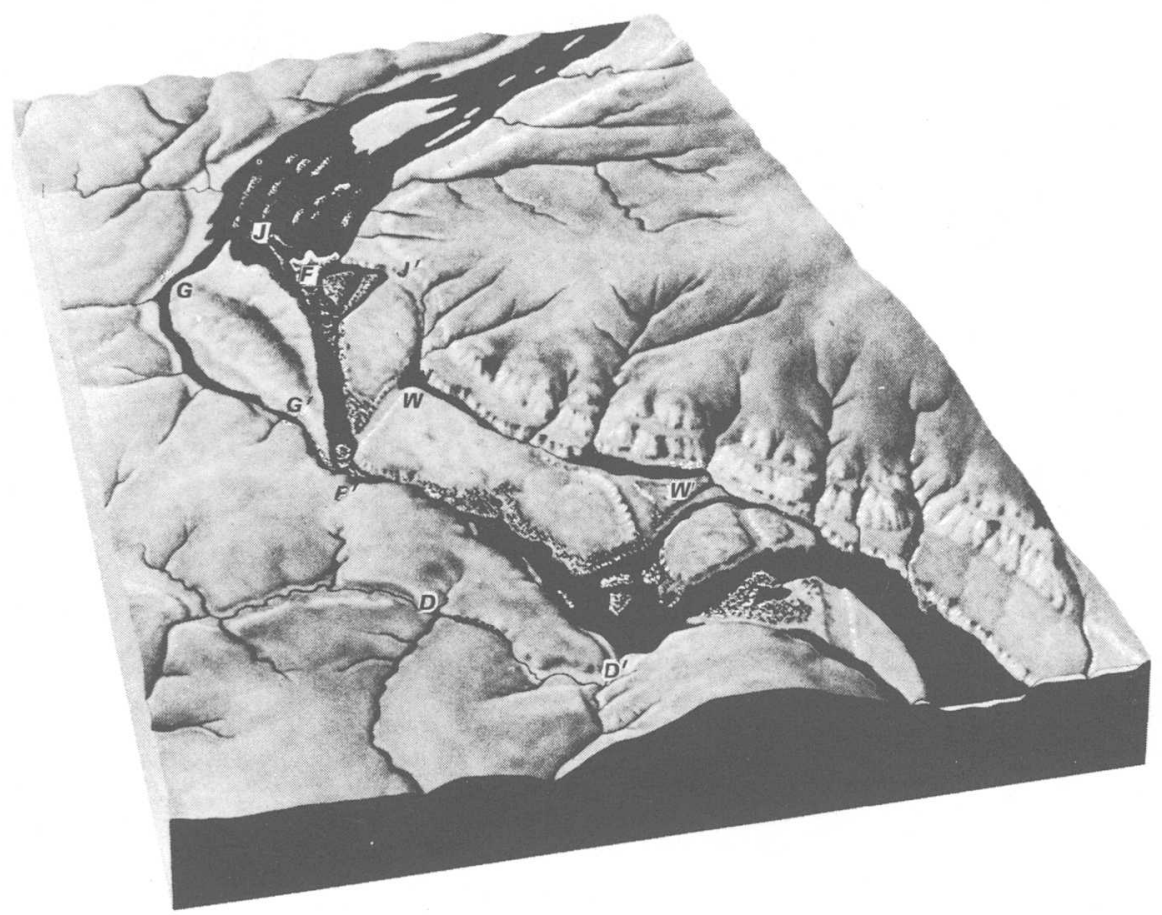

A B. The same landscape late in the Ice Age. The lowered sea level has caused the river to cut deeply into the floor of its former valley. Floods at this time may have been even higher and more frequent than they are today because of greatly increased precipitation and more frequent ice jams. The downcutting has been relatively rapid in the slightly softer rocks below Great Falls and especially rapid where the rocks are broken along a fault $\left(F-F^{\prime}\right)$. At $F$ the river encounters a series of closely spaced fractures or joints. This zone of weakness has caused the river to cut laterally ( $\left.J-J^{\prime}\right)$. Diversion of water into the deeply cut channel along the fault and fracture zone has caused the river to abandon several channels on the Maryland side, including the one now occupied by Widewater $\left(W-W^{\prime}\right)$. The channel around Glade Hill (G-G') still carries water, but it is rapidly being cut off. Continuous flow of water through this channel ceased about 9,500 years ago. Deepening of the river valley has caused Difficult Run to correspondingly deepen the lower part of its valley (D-D'), destroying its old flood plain and building a new lower one.

C. Great Falls today. Continued erosion along the fracture zone $\left(\mathrm{J}-\mathrm{J}^{\prime}\right)$ has diverted all the water from the channel around Clade Hill (G-C'). Channelways are now being cut upstream from the fracture zone, leaving Olmsted (O) and Falls (F1) Islands above river level. Construction of the dam $\left(X-X^{\prime \prime}\right)$ to divert water into the Washington aqueduct has further modified the details of the landscape above the falls. Part of Conn Island (C), for example, has been built since the construction of the dam. The abandoned channel north of Bear Island (B) has been flooded by the building of dams at W and $W^{\prime}$ so that it could be used as part of the C and O Canal. Difficult Run (D-D') continues to deepen its valley so that its old flood plain survives only above the first rapids (D). 


\section{The Origin of the Rocks}

As the Potomac River strips away the soil and cuts into the underlying bedrock, it lays bare a fascinating record of events stretching back 550 million years or more. In order to reconstruct this story, we must look beyond the obvious cracks and fractures that control the form of the river gorge and study the more subtle features of the rocks. A brief search around the Great Falls area reveals exposures of five distinct kinds of bedrock: mica schist, metagraywacke, amphibolite, granite, and lamprophyre. The mica schist, metagraywacke, and amphibolite are rocks that have been deeply buried within the Earth's crust and transformed (metamorphosed) by heat and pressure to their present state. Prior to metamorphism the schists were mudstones or shales, the metagraywackes were beds of muddy sandstone, and the amphibolites were sheets of once-molten rock similar to basalt lava.

The shales and muddy sandstones were deposited on the bottom of an ancient ocean, probably in a deep trough near the coast of a rugged landmass. Farther east, near Chain Bridge, the metamorphosed shale and sandstone grade into metamorphic gneiss formed from thick deposits of muddy sandstone containing jumbled pebbles and boulders of quartz, amphibolite, granite, and other rocks. These materials were deposited by huge submarine landslides that cascaded down the steep eastern side of the trough. The muddy sandstones at Great Falls were probably formed from thick slurries of mud and sand that moved downslope from the main slides and came to rest in the bottom of the trough. The shales at Great Falls were originally muddy sediments that were carried seaward by ocean currents and settled to the bottom during the quiet intervals between the slides. Soon after deposition of these sediments, molten lava was injected in thick sheets parallel to the layers of sandstone and shale and cooled to form the layers of basalt that later became amphibolite. The high landmass from which these sediments were eroded has long been obliterated, but it probably lay only a few kilometers to the east. It was made up largely of granitelike rocks similar to those exposed today near Baltimore, which are about 1,100 million years old.

The exact time when the sediments were deposited is uncertain because no fossils have been found in them, but dating of a rare radioactive mineral (zircon) indicated that the basalt layers were intruded about 550 million years ago, and the sediments are probably about the same age. 

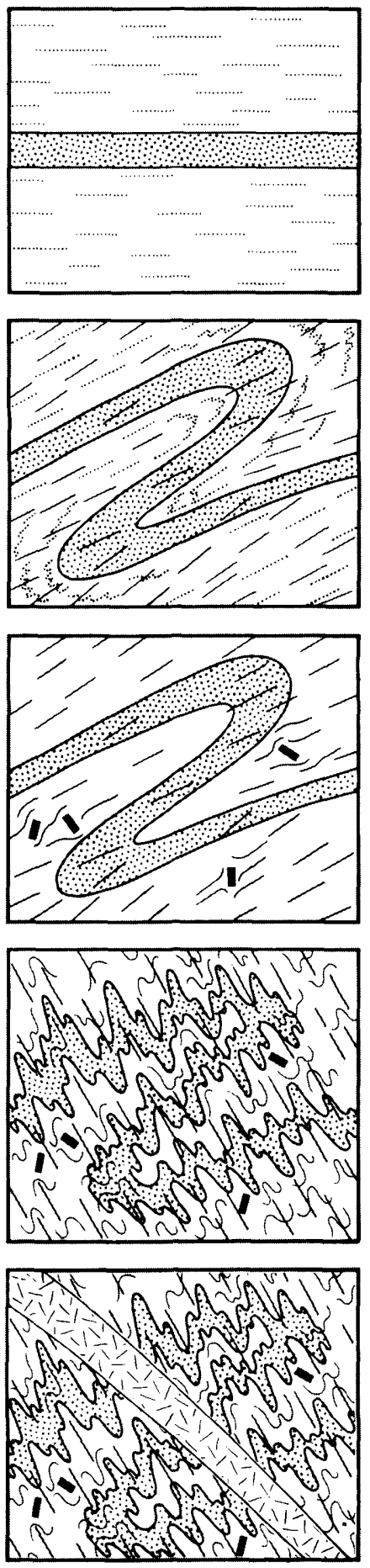

Rocks are fractured and molten material wells up along the cracks to form granite intrusions. Kyanite and andalusite are altered to sillimanite. Still later lamprophyre dikes (not shown) are emplaced. 
Since they were first formed, these rocks have undergone a full and varied history. As younger sediments accumulated above them, they became accordingly more deeply buried. They were later compressed, folded, metamorphosed, and finally intruded by granite. The different stages in this complex sequence of events are outlined in the accompanying figure. The total thickness of sediment that accumulated can be inferred from laboratory experiments which show that some of the minerals that grew in the schists when the granites were intruded require temperatures of more than $650^{\circ} \mathrm{C}$ and pressures corresponding to depths of 20 to 30 kilometers. The exact age of this deformation and recrystallization is unknown, but dates on mica from granite near Great Falls indicate that the granite was emplaced about 470 million years ago, and most of the deformation must have been accomplished by that time.

Thus far in the history of these rocks, events were controlled by forces deep within the earth which led to the downbuckling of the sea floor, accumulation of sediments, and later compression and folding. After the emplacement of the granite, however, a fundamental change took place; the Earth's crust stopped moving down and slowly began to rise again, carrying the Great Falls rocks back toward the Earth's surface, where we find them today. As the crust rose, overlying rocks were eroded and the resulting debris was transported westward, where it accumulated as thick sedimentary deposits which now make up the main part of the Appalachian Mountains. Erosion was very rapid during the initial stages of this uplift, suggesting that the Piedmont area at that time was very mountainous, perhaps like the Rocky Mountains today.

As erosion followed uplift, temperatures in the rocks at Great Falls. gradually declined, and the rocks became fractured as they cooled. Along some of the fractures, molten rock material of a different type rose and solidified to form the sheets or dikes of lamprophyre, another dark lavalike igneous rock. Dating of the minerals in the lamprophyre dikes shows that they were intruded about 360 million years ago. Still later, movement occurred along other fractures, shattering and crushing the rocks along them and displacing the rocks on either side. Zones along which such movement has taken place are called faults. The straight narrow section of the gorge below Rocky Islands is cut along one such fault. The river follows the fault zone because the broken rock along it is much more easily eroded than the unbroken rocks on either side.

Along some of the faults, hot solutions have risen and deposited thick veins of white quartz. Some of these veins carry small amounts of gold, 


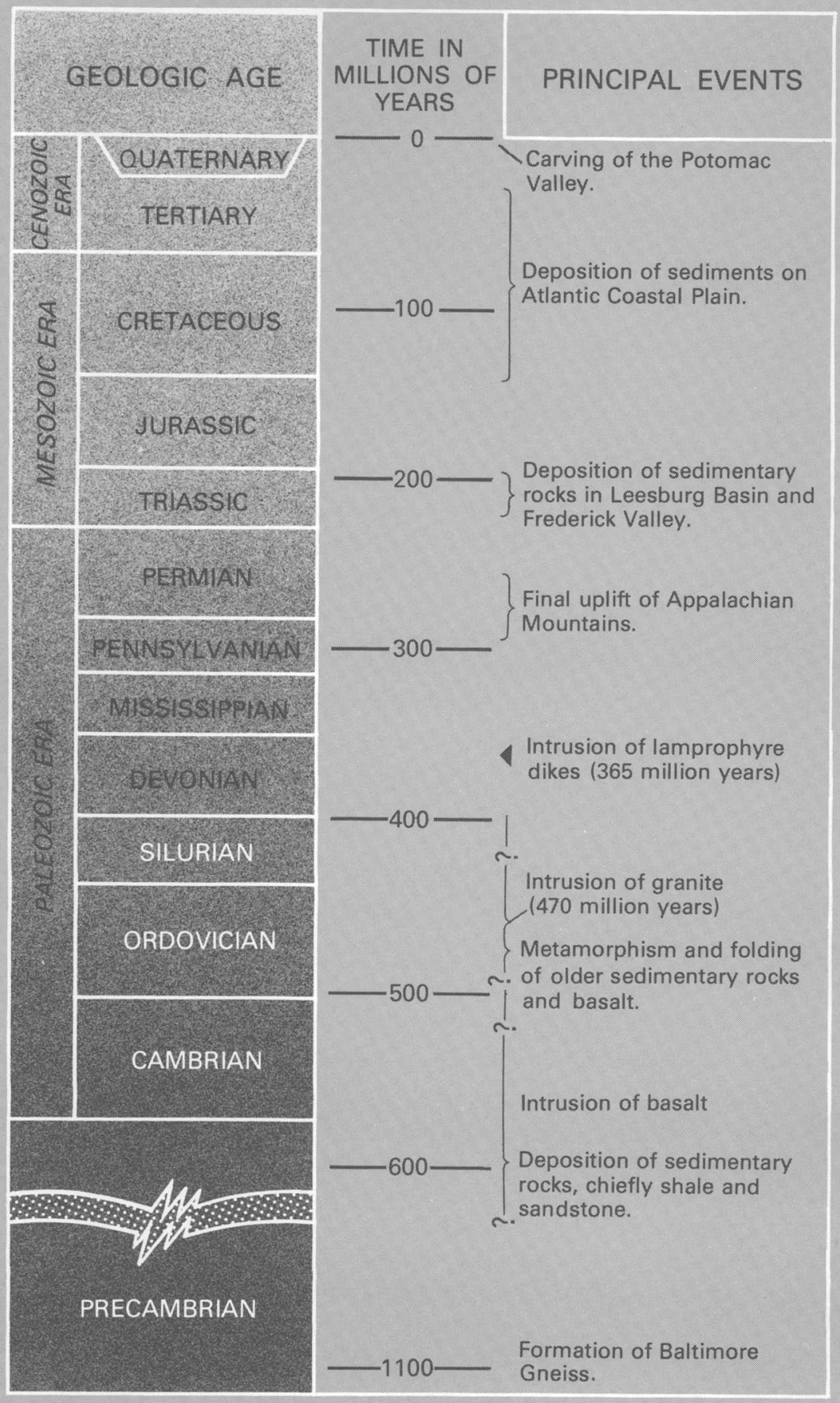


The rocks of Great Falls

Name

Description

Color

Original rock

Mica schist

Metamorphic rock containing abundant coarse flakes of mica oriented along parallel planes. Thin veinlets of quartz cutting the schist stand out as a delicate network of ribs on weathered outcrops.

Metagraywacke Metamorphic rock composed of fine-grained quartz, feldspar, and some mica. Has a sugary texture on weathered outcrops; occurs interstratified with mica shist in layers a few centimeters to a meter in thickness.

Amphibolite

Metamorphic rock composed of dark green to black crystals of hornblende in white to pink feldspar; occurs in layers half a meter to 35 meters in thickness.

\section{Granite}

Intrusive igneous rock composed of quartz and feldspar with mica; occurs as dikes and irregular masses.

\section{Light bluish \\ Muddy gray to buff. sandstone.}

\section{Silvery gray; Shale or weathers to mudstone.} reddish brown.

\section{Dark green to black.}

Basalt.

$$
\begin{array}{rr}
\text { White to pink. Original rock } \\
\text { essentially } \\
\text { unchanged. }
\end{array}
$$

Dark green.

$$
\begin{gathered}
\text { Original rock } \\
\text { essentially } \\
\text { unchanged. }
\end{gathered}
$$




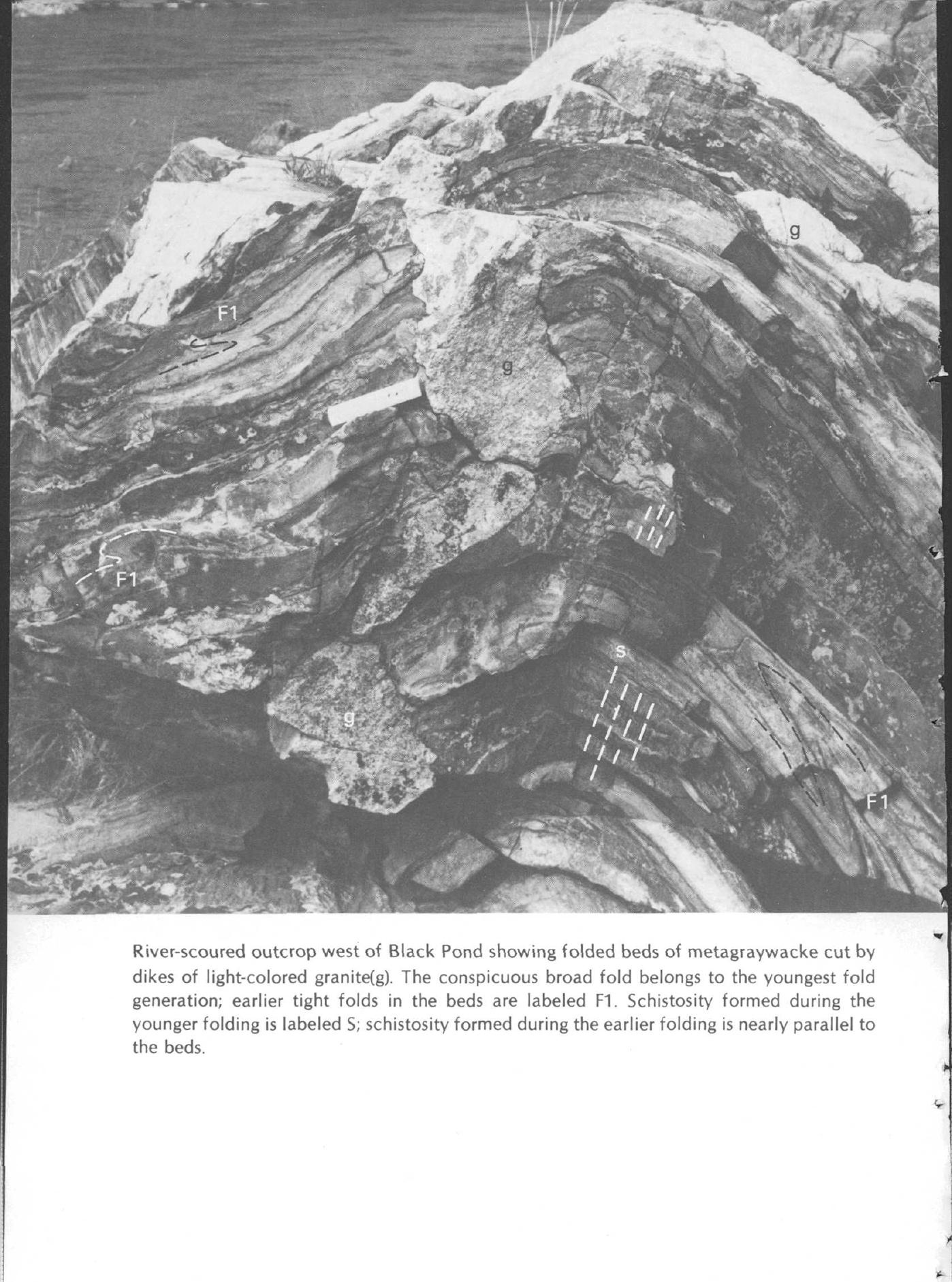


which was mined sporadically in the area from 1867 until as recently as 1941. Many of these faults and quartz veins have the same orientation as faults of Triassic age (about 200 million years old) a few kilometers to the west, and the faults at Creat Falls may be of the same age.

The Triassic faults appear to have developed in response to a final stage of uplift, a regional arching and stretching of the Piedmont rocks, which produced a series of fault-bounded basins by subsidence of keystoneshaped blocks. These basins were then filled with the red shales and sandstones which crop out a few kilometers west of Great Falls in the Leesburg Basin and Frederick Valley.

At this stage in the geologic story, we have come full circle; the record of the rocks merges with the origin of the river and the development of its valley. But the chronicle of the river and the rocks is told best not by words and sketches on a printed page, but by the face of the land and by the rocks themselves. To read the story for yourself, you are invited to follow one of the trails described in the trail logs.

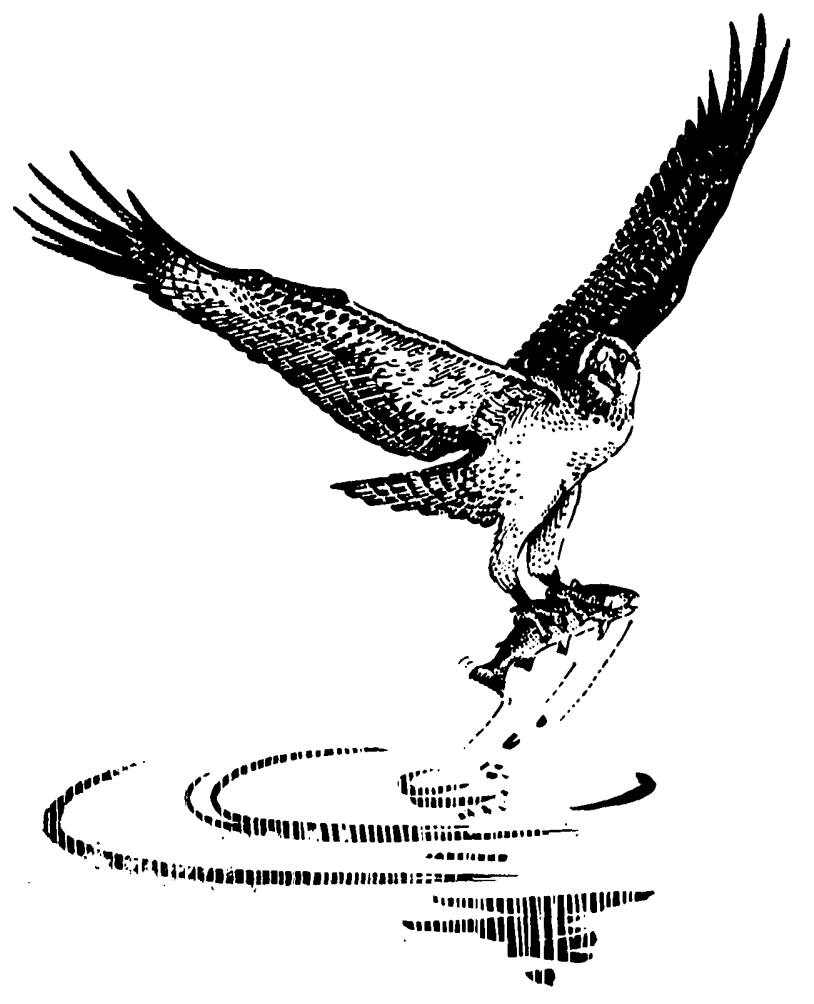




\section{A Few Words About the Forests}

The original forests of Great Falls Park have been almost completely cut over since 1790; only a few trees on the hill north of Difficult Run remain from presettlement times. After repeated cutting and clearing, fires, and high water, most of the forest lands now support only secondor third-growth trees.

The various types of plants growing in the area reflect differences in landscape features and the availability of water. Forty-three species of trees have been recognized; their distribution and the associated groupings of shrubs and wild flowers for the five major subdivisions of the forest landscape are summarized in the table.

The distributions of several tree and shrub species are puzzling. For example, red oak is common on the bedrock terrace but is not found on the islands and flood plains above the falls, whereas its closest relative, the Shumard oak, is found there. Post oak is common on the bedrock terrace and is rare on the upland. Black oak is common on the upland but absent over much of the bedrock terrace. Why do these (and others) grow only in certain places?

Even more puzzling is the distribution of the woody, yellow-flowered St. John's Wort, Hypericum densiflorum. It is common in open areas on the bedrock terrace and on rocky islands downstream to Chain Bridge. It does not grow elsewhere in the local area but is common in the Appalachian Mountains south to North Carolina. The moss, Crimmia laevigata (Stop 4, Virginia trail log; and Stop 2, Maryland trail log), grows only on the cliffs below the bedrock terrace here and in similar places downstream. It, too, is common in the mountains. Other such strange distributions could be mentioned. What factors control the distribution of these species?

The vegetation of the Great Falls area was different in the past. A partial history of the changes in the forest during the last 16,000 years has been pieced together by microscopic study of pollen grains preserved in local swamp deposits. The relative number of pollen grains of various kinds in the sample tell us much about the forest that produced the pollen. Core samples were taken from two places in the Great Falls area. One core, 1.2 meters long, was taken from the swamp west of Glade Hill; and the other, 3.7 meters long, was taken from a bog south of Anglers Inn. The organic material at the bottom of the Glade Hill 


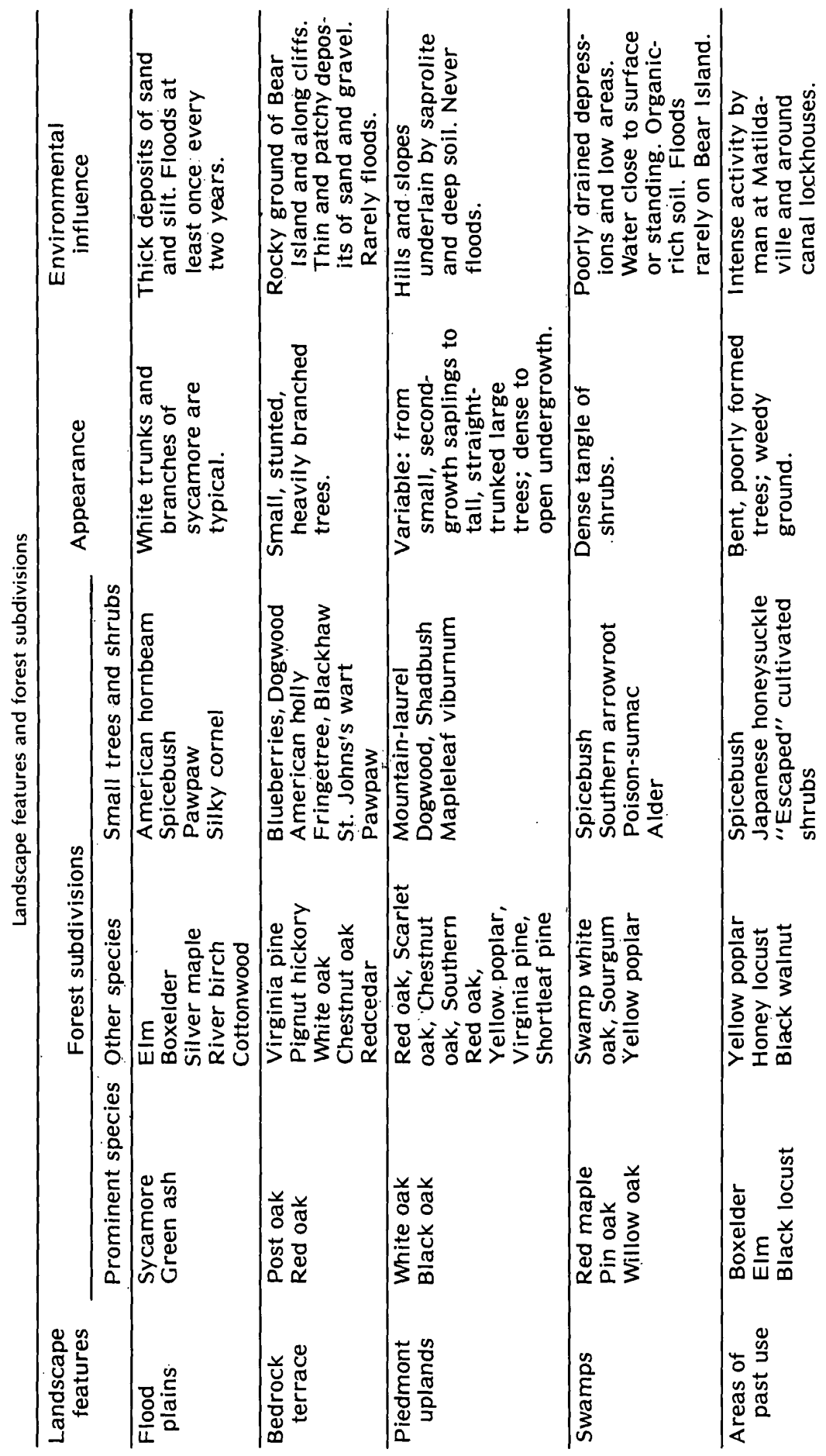


swamp is about 9,500 years old; that in the bog near Anglers Inn is about 16,000 years old. Ages are determined by measuring the amount of radioactive carbon $(\mathrm{C}-14)$ that the organic matter contains.

The fossil pollen has been studied only for the samples from the deeper bog. It indicates that about 16,000 years ago, the hills surrounding Great Falls were covered with a spruce-jack pine woodland growing in a subarctic climate. Jack pine now grows only as far south as the northern tier of States. Spruce grows not only in the northern tier of States but also down the backbone of the Appalachian Mountains to Tennessee.

Sometime between 12,000 and 13,000 years ago a few scattered oaks, hemlocks, and alders began to grow. By 8,000 or 9,000 years ago the forests began to resemble those we see today. Spruce and jack pine were still present, but chestnut, hickory, elm, maple, and walnut were present along with increasing numbers of oak and Virginia pine. The oak-pine chestnut forests, as seen by the first settlers to this area, have been here only 5,000 years or less.

What caused these major changes? At least four times between 2 million and 12,000 years ago, much of the Northern Hemisphere was covered with vast ice sheets. The last glacial advance reached its southern limit, from Long Island across Pennsylvania and central Ohio, about 18,000 years ago. Although the glaciers never reached as far south as the Potomac River, the climate was much colder than it is now; in fact, this vast amount of ice had a marked cooling influence on the climate that affected the vegetation at least as far south as Florida and Louisiana.

The catastrophic changes in the forests wrought by the early settlers are recorded by the pollen. As the region was settled, the area of forest land and the numbers of trees and shrubs declined drastically, while ragweed and grasses markedly increased. The settlers cut down and burned trees and plowed the land, thus encouraging the growth of grasses and weeds. Henry Lee, who was granted land now called Sully near Dulles Airport, wrote in 1732 that he was happy to see brush fires built by freeholders to remove the unwanted trees and shrubs. The Great Falls area was farmed extensively for about 120 years, but gradually, as cultivated fields were abandoned, forest plants again started to grow. At first pines were dominant but hardwoods also were present. Pines grow more rapidly and reach maturity sooner than hardwoods and produce more pollen. Thus, the fossil record shows a predominance of pine. However, the forests bordering the Potomac near Great Falls have tended to return gradually to their presettlement com- 
position. Grasses and weeds, which grow in pastures, parkland, and backyards and along highway rights-of-way, are still more abundant than before settlement. The relative proportions of tree species in the present forests approach what they were in the presettlement forests. The exception, of course, is the American chestnut, which disappeared during the blight of the 1920's and 1930's and was replaced by oaks and hickories. The sketches of leaves shown in the trail logs have been added to assist in identifying the numerous species of trees growing in the park.

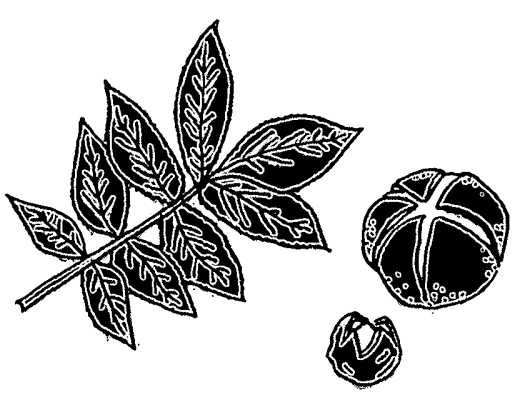

mockernut hickory

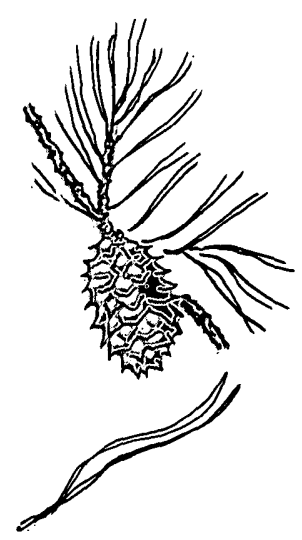

Virginia pine

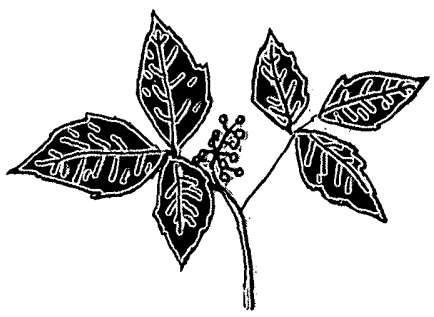

poison-ivy

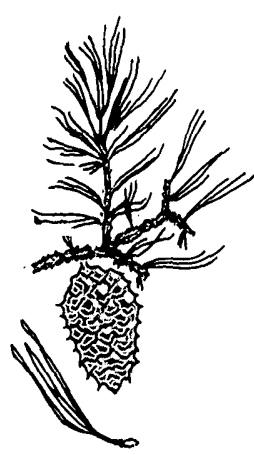

pitch pine 


\section{Trail log-Great Falls, Virginia}

This walking tour is designed to acquaint you with the important geological, botanical, and ecological features that can be seen from the park trails. The entire tour is about 7 kilometers long and takes about 6 hours. It includes two steep climbs. The tour can be shortened to 3.7 kilometers, however, by a shortcut that avoids the two steepest climbs. Good hiking boots and rough clothing are recommended.

\section{Kilometers}

0.00 From south entrance of Visitor Center, walk about 40 meters south to first footbridge across old Patowmack Canal. Cross bridge and follow trail toward river to overlook at brink of Great Falls.

0.12 Stop 1. A CLOSEUP OF CREAT FALLS. The total drop of the river from the uppermost rapids to the channel below this overlook is about 12 meters; the cascade in front of you is 5 meters high. The narrowest part of the channel below the falls here is 23 meters wide at normal stages of the river. The foam commonly seen below the falls is detergent suds-evidence of water pollution from towns and cities upstream.

The rock here is metagraywacke, a type of muddy sandstone that has been altered (metamorphosed) by heat and pressure into hard metamorphic rock. The conspicuous layers in this outcrop are the original layers in which the mud and sand were deposited on the sea bottom but which were turned on edge as the rocks were folded. The sand grains in some of the layers are as large as BB's, but most of the sand is much finer.

box elder

The same layers are plainly visible in the rocky islands in the middle of the falls. Note how the river channels follow the rock layers.

Notice that in many of the metagraywacke layers the largest sand grains are concentrated at one side of the layer and the grains gradually become finer toward 
the other side of the layer. This is called graded bedding. Its origin and how it allows us to distinguish tops and bottoms of metagraywacke beds are explained in the discussion of Stop 1, in the trail log on the Maryland side of the river. Notice that most layers here have tops to the west, but there are a few with tops to the east. This suggests that the layers have locally been folded completely back on themselves. Can you find any other evidence of tight folds in the metagraywacke layers in this vicinity?

The straight fractures that cut across the rock layers are joints. They formed as the rocks were uplifted and cooled. The most conspicuous joints are nearly vertical and perpendicular to the folded metagraywacke layers. These joints break the rock into blocks, making it easier for the river to quarry away the resistant layers.

Return to path along old Patowmack Canal, turn left and walk south (downstream).

0.35 Marker here shows relative levels of 1936, 1942, 1972, and 1937 floods. At normal stages the water in the channel below the falls is about 10 meters deep. In 1936 the water in the middle of the river was more than 30 meters deep. Turn left here and walk about 50 meters to overlook.

0.40 Stop 2. VISTA OF THE FALLS AND VIEW OF THE OLD RIVER BED. The level surface on which you stand was part of the bed of the river before the gorge was cut and the falls were formed. From here you can trace the surface upstream and see that it becomes the present riverbed a few hundred meters above the falls.

Notice the nearly right-angle turn in the river at this point. Above this point the river is following the metagraywacke layers; here it turns to follow a zone of weakness caused by closely spaced joints like those visible at Stop 1 . This zone is $J J^{\prime}$ in the block diagram.

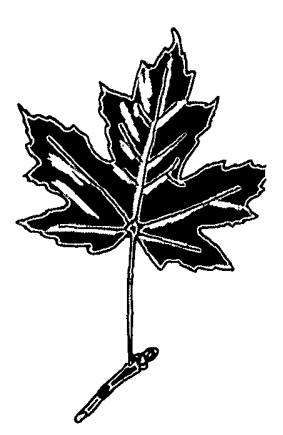

silver maple

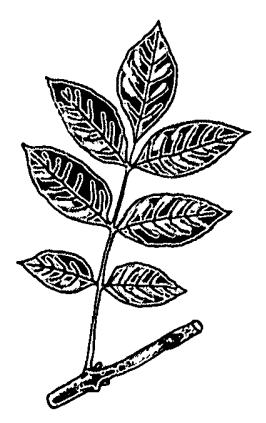

green ash 
Return to path along Patowmack Canal and continue south (downstream).

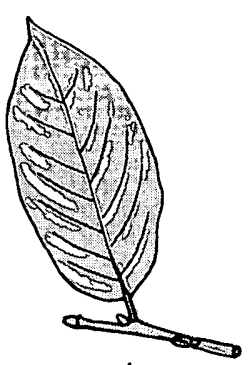

persimmon

0.62 Pass into woods.

0.70 Large outcrop of rock in trail. This rock is mica schist containing lenses and pods of white quartz. Notice how the layers are crumpled and folded. This occurred during metamorphism that converted the rock from shale to schist.

0.77 Trail fork. Follow left fork. Trail follows top of an old stone wall. This wall held a large pond that served as a collecting basin for water needed to operate the Patowmack Canal. The pond also provided room for mooring barges waiting to be locked through. This area held water until 1830 , less than 150 years ago. The basin is now filled with mature trees, indicating that when man's activities cease, the forests return. As part of the restoration of the Canal, these trees will be removed and the basin refilled with water.

0.91 Trail junction. Continue about 10 meters straight ahead to break in wall below which is a small stream channel. This was the waste weir that drained excess water from the collecting basin. A saw mill driven by an undershot water wheel once straddled the weir. Retrace your steps about 10 meters and turn right on trail.

0.97 Trail fork. Follow blue-blazed trail to right and down a series of steps into an 8-meter-deep stream valley.

1.00 Cross creek. The valley on your right as you face upstream has been cut by the stream along a series of thin lamprophyre dikes, several of which are exposed in the small waterfall about $15 \mathrm{~m}$ upstream from the trail crossing. This stream drains the waste weir you just saw; the location of the stream was controlled by the presence of the dikes and the waste weir was placed to take advantage of the stream. 


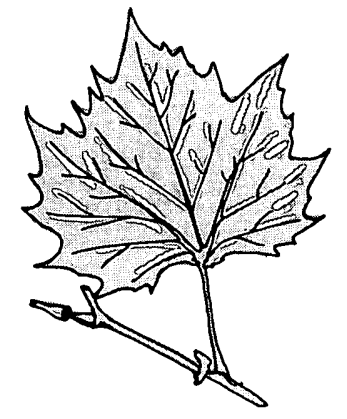

sycamore
Almost directly across the river are three lamprophyre dikes, 20 to 40 centimeters thick, filling some of the conspicuous joints that dip steeply upstream. These are the same dikes as those exposed in the small stream valley you just crossed. The dikes look as though they should project across the river to about this point, but the extension of them on this side of the river is about 25 meters upstream. This offset is caused by a fault that lies beneath the river. The straight steep-sided gorge here has been cut by the river in the crushed and broken rock along the fault, which is more easily eroded than the solid rocks on either side.

The rock here is mica schist. About 8 meters to the north (upstream) is a vein of quartz more than 30 centimeters thick. Gold was mined from similar veins at several nearby places on the Maryland side of the river.

The trees here are eastern red cedar, Virginia pine, red oak, pignut hickory, fringe tree, ash, and blackhaw.

Return to blue-blazed trail and turn left (downstream).

Follow blue-blazed trail downstream along brink of gorge past river-smoothed outcrops of mica schist.

1.27 Trail junction. Blue-blazed trail turns right. Continue ahead $\mathbf{4 0}$ meters gently downhill to twin-trunked ash tree on left side of trail. This tree is living testimony of the flood of 1889 (the year of the first Johnstown flood). The original trunk grew vertically until it was tipped over by floodwaters. The two vertical trunks started to grow at that time. Their age, determined by counting rings, tells us the year the tree was tipped. Records show that the $\mathbf{1 8 8 9}$ flood was as large as that of 1936 and easily would have reached this level. Other trees in this vicinity are ash, chestnut, red oaks, and bitternut hickory (the large tree with light-gray ridged bark).

Flood felling of trees continues. In the small depression that the trail follows for the next 50 meters are many inclined trees with vertical sprouts. These were 
felled by the flood following hurricane Agnes in June 1972, when water was at least 3 meters deep in the lit-

tle valley. Most of these trees are eastern hophornbeam.

Retrace steps to trail junction; turn left on blueblazed trail. For about 40 meters the trail crosses the lower collecting basin for the old Patowmack Canal, once held by still-apparent retaining walls.

Ash tree showing damage from 1889 flood. Man is drilling to take core used to determine year in which the vertical sprout began to grow

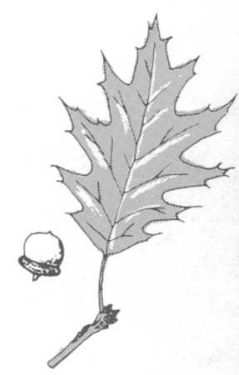

red oak

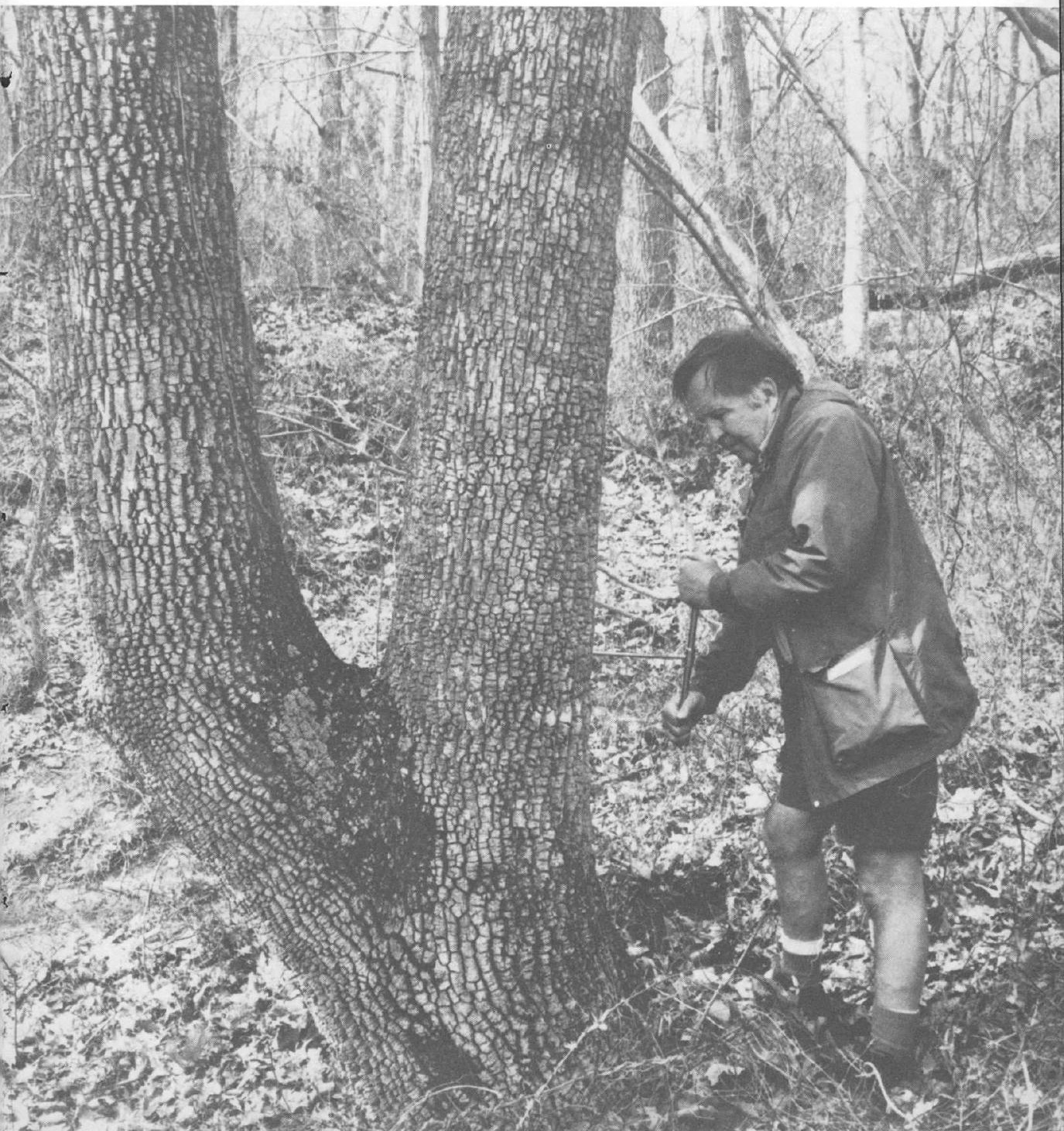


1.34 Trail junction. Follow blue-blazed trail to left.

1.38 Ruins of lift lock on Patowmack Canal. The lock is built chiefly of reddish-brown sandstone that was quarried near Seneca, 13 kilometers upstream, and carried down river by boat. The same "Seneca Stone" was used in many of the older buildings in downtown Washington, including the Smithsonian Castle on the Mall.

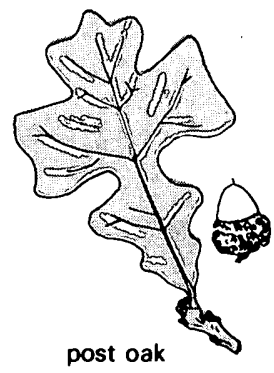

1.48 Junction with blue-blazed trail. To your left about 10 meters down the blue-blazed trail is a twin-trunked white oak tree. The trunks, each almost 70 centimeters in diameter, sprouted from a stump. They began to grow before 1818 . The original main trunk may have beencut for timber for the lock gates on the Patowmack Canal shortly before that time.

Continue straight ahead.

Between this trail junction and the next stop, you pass through a red oak and post oak forest, typical of the bedrock terrace. Also growing here are Virginia pine, cedar, pignut hickory, white oak, and chestnut oak. This type of forest is also present on the flat surface above the cliffs across the river.

About 140 meters from the junction is a shallow pond west of the trail. The pond occupies a depression that was once a side channel of the river.

pignut hickory

In early spring a metallic, discordant chorus of wood frogs can be heard coming from the pond. The fern that blankets some of the nearby rocks, especially on the far side of the pond, is the common polypody. It grows only on the rocks along the river from Turkey Run to Blockhouse Point.

The next stop is along the trail opposite the south (downstream) end of the pond. 
of the falls. Notice that, although the general shapes of the rock outcrops are rounded, all of the rock surfaces have been roughened by weathering since they were polished by the river. Some of the pebbles left by the river can still be seen in the potholes and wedged in crannies in the rock outcrops.

Leave trail and walk carefully over to edge of gorge.

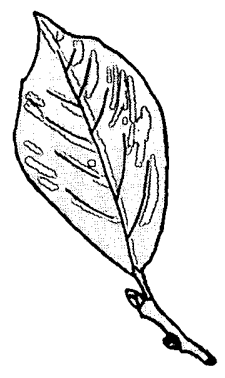

sourgum

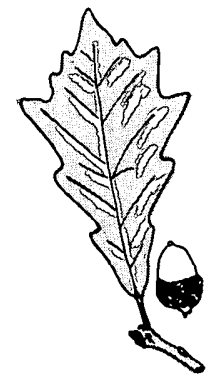

swamp white oak
Large potholes can be seen at the present river level and many smaller ones at the top of the cliffs on the Maryland side.

Looking upstream you can see evidence of the effect of flooding on plant life. Near the tops of the cliffs the rocks are rough and sharp and are covered by several species of gray lichens. Some are leaflike; others are tight crusts cemented to the rock. The large ones that look like warty, gray potato chips are Umbilicaria. The light-gray, spreading ones are Parmelia conspersa. The gray crust that requires close examination to see is Lecanora cinera. The lichens are alive. If watered they turn soft and green in 5 to 10 minutes. Floods reach these levels only rarely, perhaps once every 10 to 20 years.

About 6 to 9 meters below the cliff edge is an irregular band marked by dark-olive-green patches of moss (Crimmia laevigata). This species is common on many kinds of rocks in the Creat Smoky Mountains and southern Blue Ridge; here it is growing at its northernmost limit. This zone is flooded about once every 2 years. Below the moss and extending down to 3 to 6 meters above normal water level, the rocks have a yellow cast which is due to lichens (Candelariella vitellina). This zone is flooded several time each year.

Near the base of the cliffs, just above normal water level, the rocks are covered with a metallic purplishblack coating that consists of iron and manganese oxides. This stain is the result of acid mine drainage from coal mines in the upper Potomac River basin.

Return to trail and continue south (downstream). Trail follows narrow trough between rock rib at edge of 
river gorge and steep hillside on right. About 20 meters before the trail reaches the south end of the rock rib is a large rounded boulder on the left. This is Stop 5.

1.74 Stop 5. A GEOLOGICAL PUZZLE. Along the trail are many rounded pebbles, cobbles, and boulders left behind by the river when it flowed at this level. This boulder, 1.5 meters in diameter and estimated to weigh over 4 metric tons, is the grandaddy of them all!

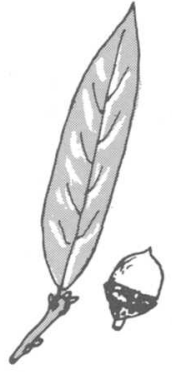

willow oak

Diabase boulder at Stop 5 .

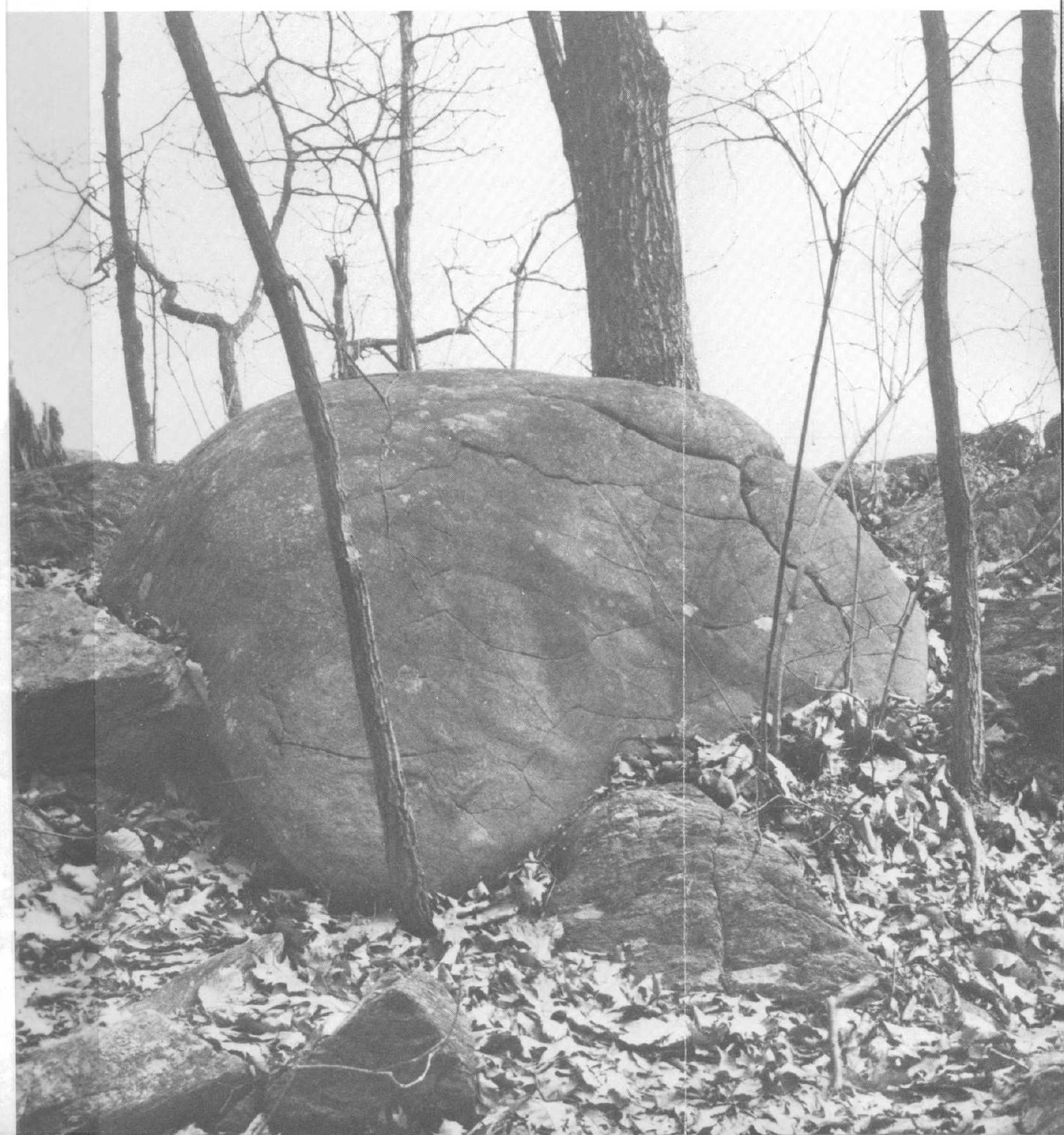



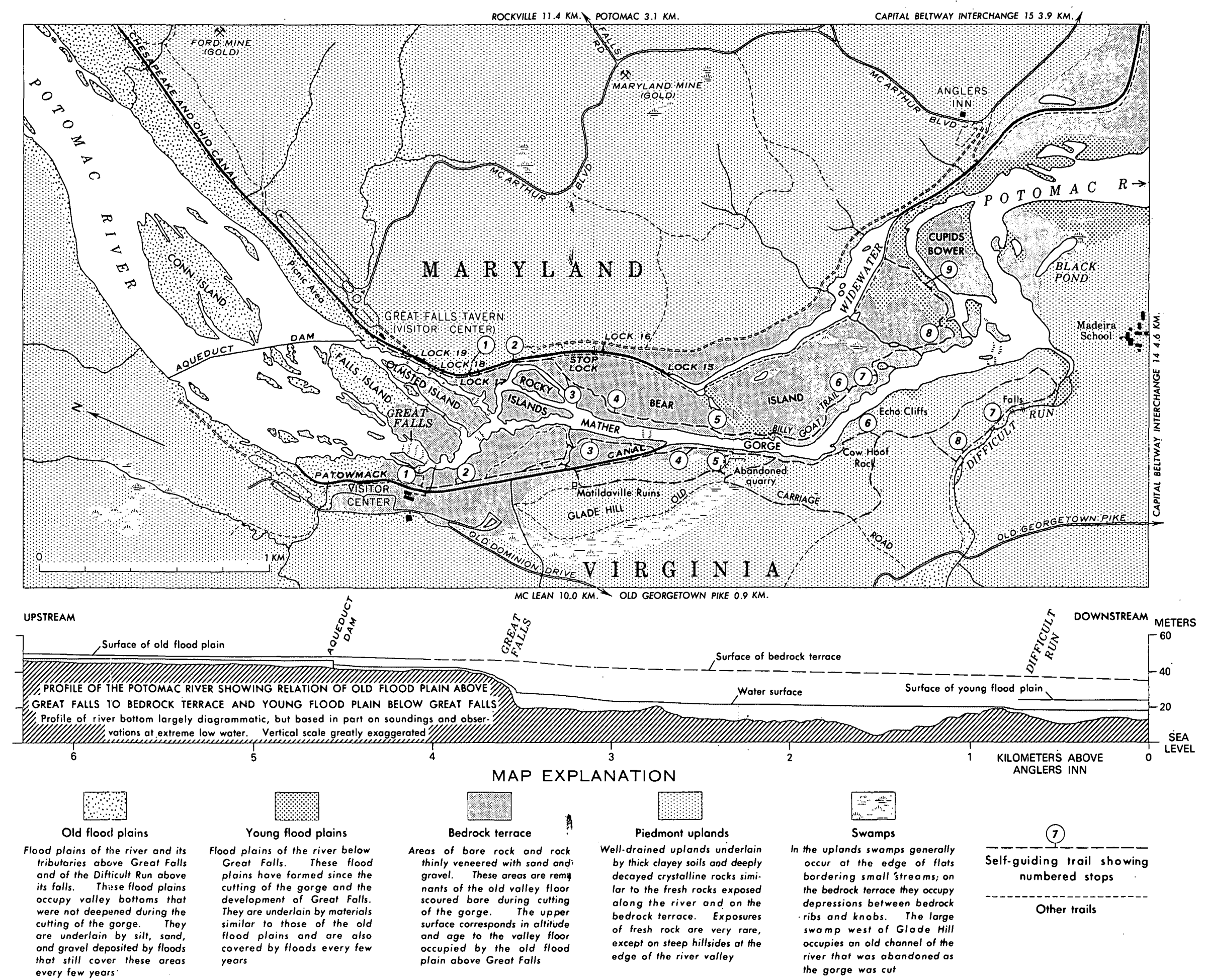

TRAIL MAP OF THE GREAT FALLS AREA SHOWING LANDSCAPE SUBDIVISIONS 


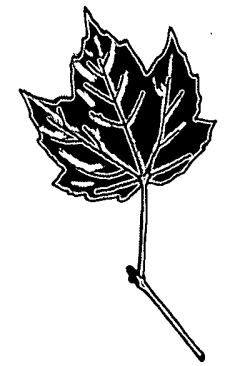

red maple

It is composed of a dark, heavy igneous rock called diabase. The nearest outcrop of such rock is near Blockhouse Point, more than 11 kilometers upstream. This boulder is far too large to have been moved by even the largest modern flood. Could it have floated in an ice jam or in a tangle of logs? Or does it indicate even larger and more violent floods, perhaps during the Ice Ages when the cutting of the gorge took place?

Continue downstream. After about 20 meters the trail skirts a deep cleft down which you can see directly to the river, 15 meters below. The trail continues along a narrow bench that is a continuation of the bedrock terrace. The bench here is slightly below the terrace on the opposite side of the river and probably marks the bottom of a channel cut in the terrace.

1.79 Most of the rocks are mica schist, but here is a dike of pegmatite, a coarse-grained rock with the same mineral composition as granite. It is composed of glassy gray quartz, pink to white feldspar, and conspicuous plates of silvery mica (muscovite). The black prismatic mineral is tourmaline. A sample of mica from this dike has been dated as $\mathbf{4 7 0}$ million years old by the potassium-argon method of radiometric dating.

1.90 Trail passes behind (west of) rock rib, no doubt once a narrow rocky island. The sand in the bottom of the depression between the rock rib and the hillside to the west was deposited by modern floods. It is littered with small shells identical to those of snails that live on the aquatic plants in the sluggish parts of the river above Great Falls. These shells will probably not survive more than a few decades of weathering. A few - meters to the north, however, you passed large boulders that were probably carried down when the main river flowed at this level. Among them is a 80 - by 40-centimeter boulder of Catoctin Greenstone, an ancient volcanic rock from the core of the Blue Ridge.

1.93 Trail skirts left of small pond. Note quartz veins and intricately folded layers in schist on south side of outcrop on left. These folds were formed during the main period of folding of the schist and metagraywacke. 
2.00 Trail emerges onto an improved gravel road used by rescue vehicles. The beach 50 meters to the left at river's edge is known as Sandy Landing. It was once the site of a ferry to the low area across the river. During the early operation of the Patowmack Canal, when all improvements had been made except for the completion of the locks at Great Falls, goods from upriver were portaged around the falls to this beach and loaded into barges to continue the trip downriver.

Turn right, away from river, on gravel road for about 10 meters.

2.01 Junction. Blue-blazed trail turns left. If you wish to return to Visitor's Center by a shorter route, continue straight ahead on road for about 260 meters, passing through an old stone quarry, now largely overgrown. Just beyond point where road emerges from quarry and 40 meters before it joins main graded road, turn right on well-beaten horse trail. This junction is at 5.56 kilometers of the trail log. Follow remainder of log from that point to Visitors Center.

If you wish to continue around complete loop, follow blue-blazed trail to left (down river).

2.06 Cross small stream. Follow trail along sandy bench with scattered outcrops of mica schist.

Note the abundant flood debris piled on the downstream sides of trees and other obstructions and that many small trees are leaning in an upstream direction. Trees were felled and the debris was deposited by the flood following hurricane Agnes in June 1972. Water at the crest of the flood was at least 15 meters above normal in the channel. Huge volumes of water roared through the gorge and struck the hillside ahead of you, where part of it was diverted to the right and swirled back upstream creating a huge eddy.

2.24 Pitch pine 45 centimeters in diameter and 20 meters tall. The tree started to grow before 1817 and has survived the floods of 1889, 1936, 1937, 1942, and 1972. Note the nearby trees leaning upstream. 


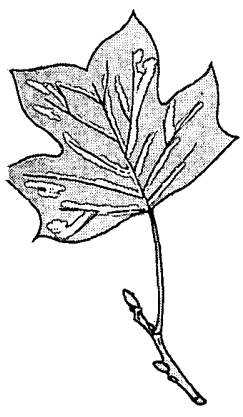

yellow poplar
2.27 To the left of the main trail are the exotic Forsythia shrubs, day lilies, and Wisteria vines. These nearly hide the remains of an old chimney. This probably marks the site of someone's vacation fish camp. It was destroyed either by the 1936 flood or possibly by an earlier one. Whoever built it thought that the large trees belied the hazard from floods. Who would have expected the normally placid river to reach such heights?

2.28 Trail junction. Well-beaten but unmarked trail leads straight ahead up hill. Follow blue-blazed trail to left. Five meters beyond the junction, the trail crosses a small stream issuing from an old cement spring box, which, no doubt, was the water supply for the cabin marked by the ruined chimney.

2.35 Trail passes behind (west of) prominent rock knob that affords good view up Mather Gorge. Rock is mica schist with several dikes of granite. Faint foot trail leads right (uphill). Follow blue-blazed trail straight ahead.

2.41 Trail begins steep climb away from river. At this level ( 9 meters above the river) the rock outcrops still retain their rounded shapes, although their surfaces are somewhat roughened by weathering since the river polished them. As you climb, notice that the rocks become rougher and more angular. Notice also that the soil along the trail is no longer river-deposited sand, but is reddish-brown clay produced by deep chemical weathering of the schist bedrock. This is the typical soil of the Piedmont upland.

2.44 Stop 6. COWHOOF ROCK. This bold outcrop 34 meters above the river affords an unexcelled view of the Mather Gorge. The straight section above the right-angle bend on your left is cut along the fault zone, which must project into the ridge behind you. Below the bend, the river follows prominent joints that cut nearly at right angles across the rock layers. Notice the potholes and river sculpture on the rocks across the river. At normal stages the river here is about 18 meters deep, whereas, elsewhere in the 


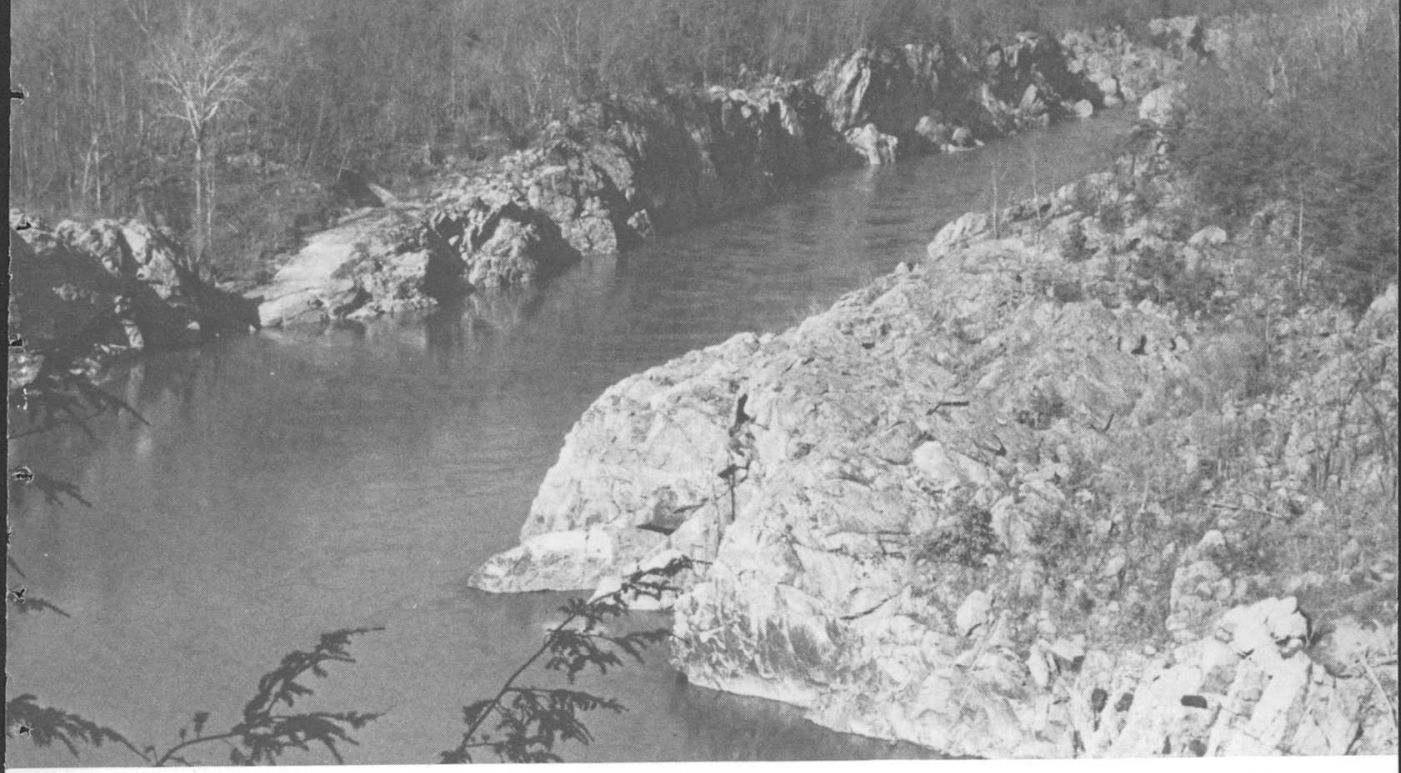

The Mather Gorge from Cowhoof Rock: $\Delta$ (A) At normal water level.

$\nabla$ (B) During flood of June 1972

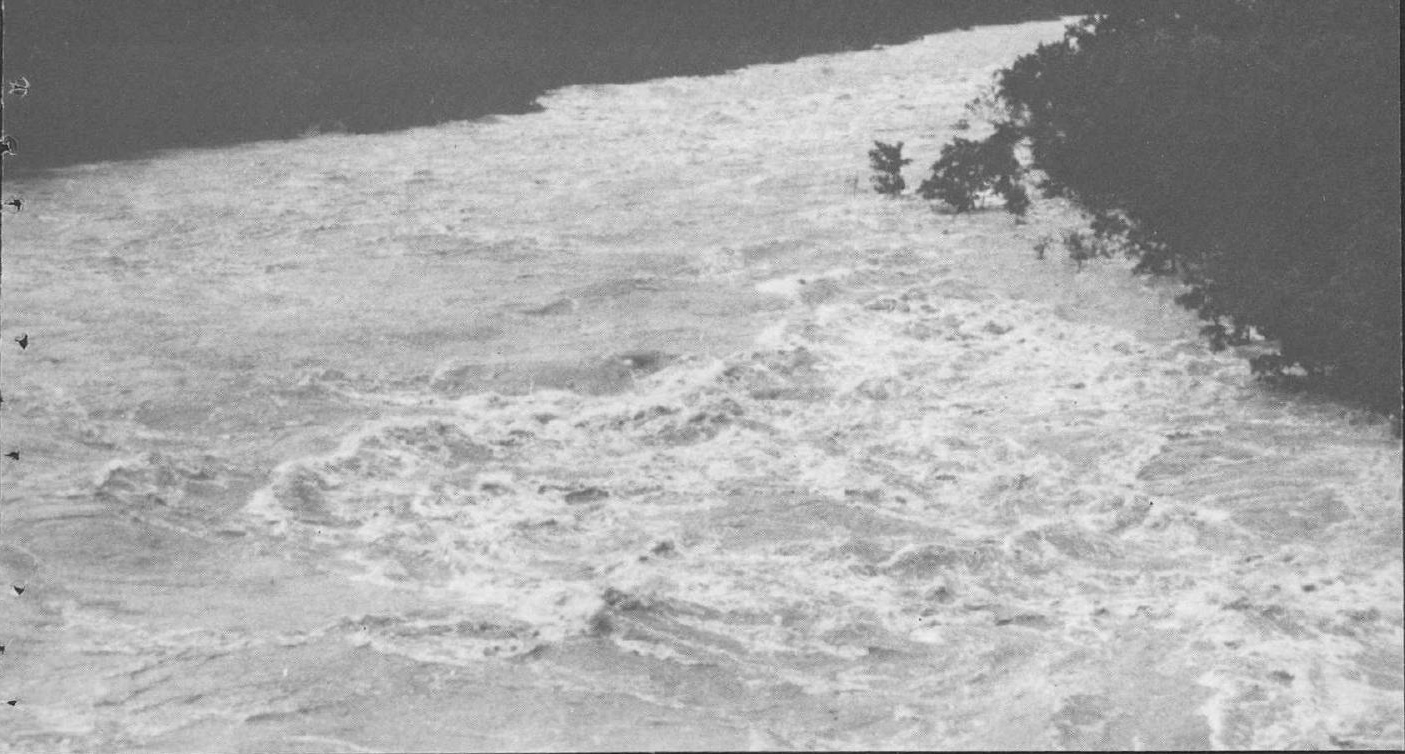




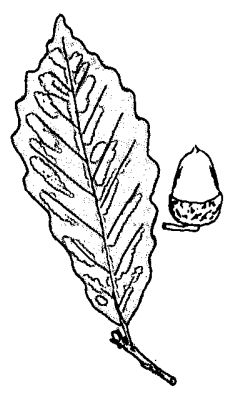

chestnut oak gorge, it is 7 to 8 meters deep. This is one of the deepest points in the river above tidewater and may mark the position of temporary falls or rapids during cutting of the gorge.

The June 1972 flood completely covered the cliff opposite you and extended into the trees on the top of Bear Island. At the crest, the water was 30 meters deep.

The evergreen shrubs are mountain laurel, which display beautiful pinkish-white flowers in May. The evergreen tree is eastern hemlock, one of the few specimens in the Park. The gnarled, twisted tree to your left is a chestnut oak. Continue up hill on narrow trail.

2.46 Thicket of small trees. A summer cabin was located here until the early 1950's. The small trees have grown since the cabin was removed. The peculiar soil with peanut-sized lumps is derived from weathering of amphibolite. A small block of unweathered amphibolite lies in the middle of the trail.

2.50 Top of hill. The ground is littered with angular pieces of white quartz derived from a large quartz vein, probably related to the gold-bearing veins to the north on the Maryland side of the river. Cavities in the quartz are due to weathering of pyrite and other sulfide minerals.

2.58 Trail junction. Turn left and follow graveled road. The forest that you are walking through is typical of the Piedmont upland. It has been cut over, but a few trees are old. The predominant trees are white, black, southern red, chestnut, and scarlet oaks. Also present are tuliptree, mockernut hickory, and Virgina and pitch pines. Dogwood and American holly are the small trees. The evergreen shrub is mountain laurel, and the small one with maplelike leaves is mapleleaved viburnum.

American chestnut was a common tree here and elsewhere in the Piedmont uplands before it was killed by blight in the 1920's and early 1930's. Chestnut 
did not grow in swamps, on the bedrock terrace, on the flood plain, or on the rocks of the Leesburg Basin. Many of the stumps along the trail in this area are chestnut.

Chemical decay of rocks underlying this ridge and others similar to it has produced a material called saprolite to depths of 30 meters or more. Saprolite is a relatively soft soil-like material that can be dug with a pick and shovel but still retains the structure and texture of the parent bedrock. Rocks this far above the river have been weathering for 1.5 to 2 million years. Saprolite is not present on the bedrock terrace because it was scoured away when the river flowed at that level, and new saprolite has not had time to form since the river has cut below the level of the terrace.

2.75 Trail junction at saddle in ridge. Well-beaten but unmarked trail to right. Follow road straight ahead up hill.

2.88 Top of hill. Gravel was hauled in to surface the road and confound geologists - it is not a natural deposit.

3.26 Outcrops of granite along road.

3.37 Trail junction 15 meters before end of road. Follow blue-blazed trail right (south). Trail descends steeply for about 20 meters.

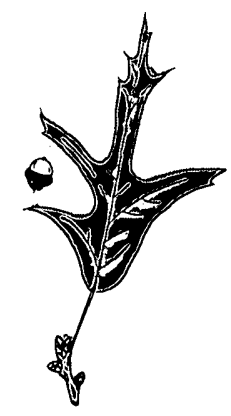

southern red oak

3.42 Trail junction. Turn right on well-beaten trail.

3.53 Trail junction. Well-beaten and deeply gullied side trail leads left down to Difficult Run. Gulley at trail junction exposes saprolite formed by deep weathering of schist. Follow trail straight ahead.

3.58 Trail junction. Follow narrow but distinct trail 30 meters left (downhill) to brink of cliff, crossing beaten trail near top of cliff. 
3.61 Stop 7. DIFFICULT RUN GORGE. This picturesque gorge with its cascades and falls was cut by Difficult Run in its efforts to keep pace with the Potomac as the river cut its gorge.

The rocks here are chiefly mica schist with a few beds of metagraywacke and numerous small dikes of granite. Notice the potholes in the bottom of the gorge-some are as large as those along the river.

Difficult Run Gorge from Stop 7.

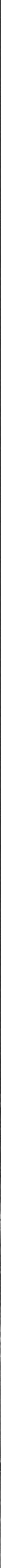


Looking downstream you can see uprooted trees and deeply eroded bank caused by the 1972 flood.

Return to main trail and turn left (upstream).

Trail follows bed of old wagon road along valley side. This is part of Towlston Road, built by Bryan Fairfax in the late 18th century, leading from a water-driven saw mill on Difficult Run to the river. The mill and the road were abandoned by 1815 .

3.75 Trail emerges on flat rock about 3 meters above stream level. Most of the flat rock face is granite, but several angular pieces of schist that spalled off the walls and were incorporated in the still-liquid granite are visible.

Continue upstream on rough rocky trail, no longer on old road bed. The rock exposed along the trail is predominantly coarse-grained amphibolite, composed of dark-green hornblende and cream-colored feldspar. The hornblende crystals are typically 0.5 to 1 centimeters in diameter and give the rock a characteristic mottled appearance.

3.86 Trail comes to bank of Difficult Run where prominent rib of rock extends almost across stream. At low water you can walk directly along the edge of the stream to the rock, but at higher water you must scramble over one of the steep narrow trails leading across or over the steep bank thai projects into the stream.

3.87 Stop 8. A VARIETY OF ROCKS. This outcrop, scoured clean by the Agnes flood of 1972, contains all the major rock types of the Park except metagraywacke.

The coarsely mottled, light-gray rock is mica schist. Some of the fresh flat faces display conspicuous darkgreen spots 1 to 2 centimeters in diameter that may be altered relicts of metamorphic minerals, possibly garnet or staurolite.

The darker greenish-gray, fine-grained rock that forms a 2-meter-thick band in the center of the outcrop is 


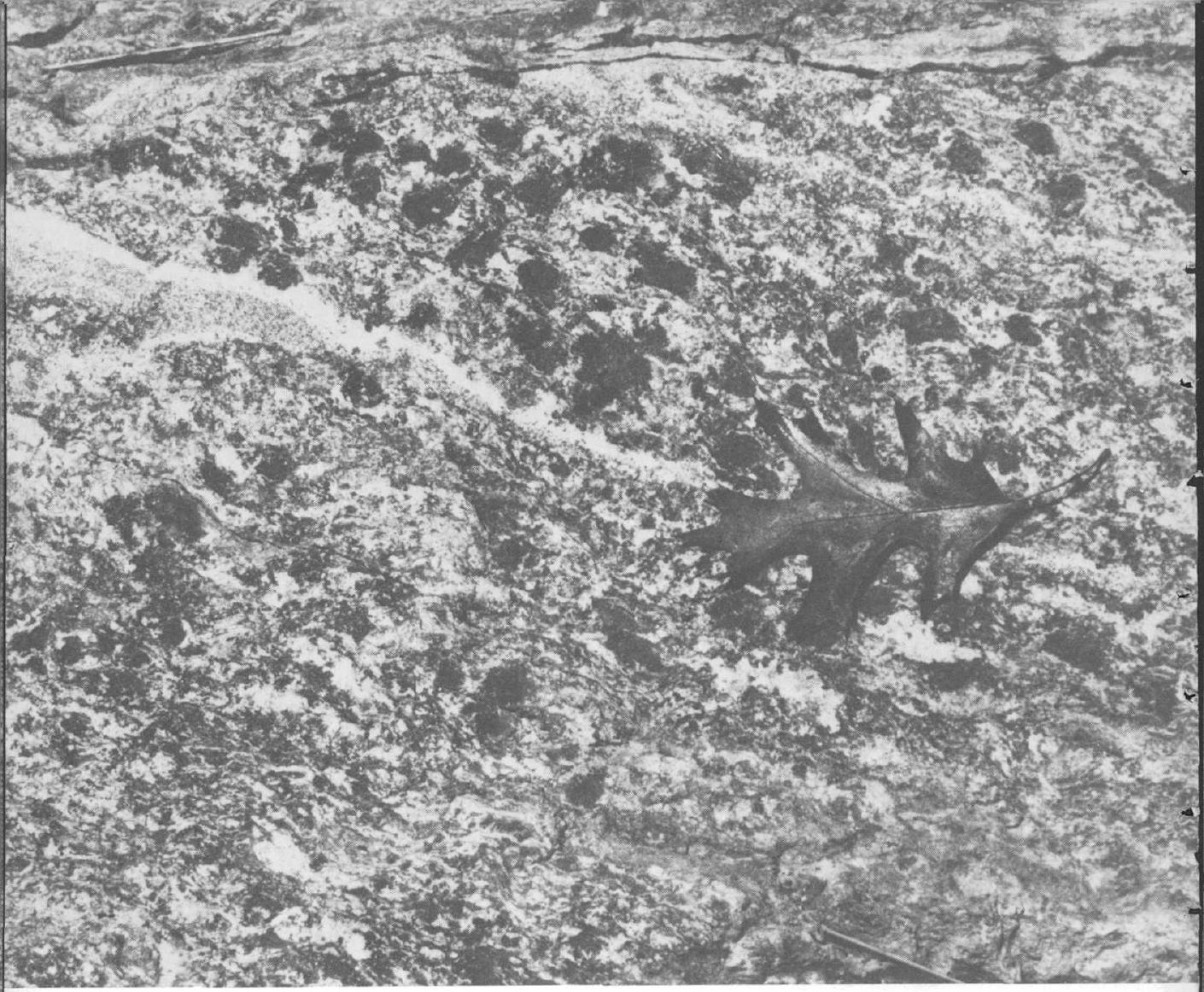

Altered relicts of garnet or staurolite in schist at Stop 8. Red oak leaf about 15 centimeters long gives scale.

amphibolite. It is not nearly as coarse grained as that exposed along the trail below, either because the original basalt from which it was derived crystallized too fast for large crystals to form, or because the crystals were crushed and broken during metamorphism.

Both the amphibolite and the schist are cut by irregular, rudely tabular bodies of streaky light-gray granite. The streaks, which are due to concentrations of black mica, probably are the result of differential flow of the pasty, crystal-rich granite liquid as it forced its way into joints and fractures in the enclosing rocks. The fact that both the contacts of the granite dikes and the flow structure within them cut across the foliation in both the schist and amphibolite shows 
that the granite was emplaced after the enclosing rocks were folded and metamorphosed.

Near the top of the outcrop, the largest granite dike is cut by an irregular body of pegmatite 5 to 15 centimeters thick. The pegmatite is composed of bluishgray glassy quartz, salmon-pink feldspar, and silverywhite mica in crystals several centimeters in diameter. The pegmatite probably crystallized from water- and vapor-rich fluids that migrated into a crack or irregular opening in the rocks when the granite had almost solidified. Radiometric dating of mica from

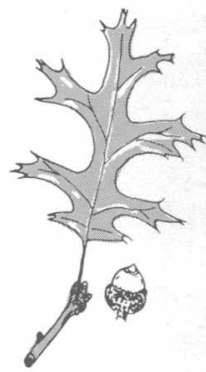

scarlet oak this pegmatite indicates that it is about 470 million years old. This is probably the age of emplacement of the granite.

Granite dike at Stop 8. Note streaks in granite parallel to the contact with the enclosing schist and how the contact cuts across foliation in the schist. Post oak leaf about 12 centimeters long gives scale.

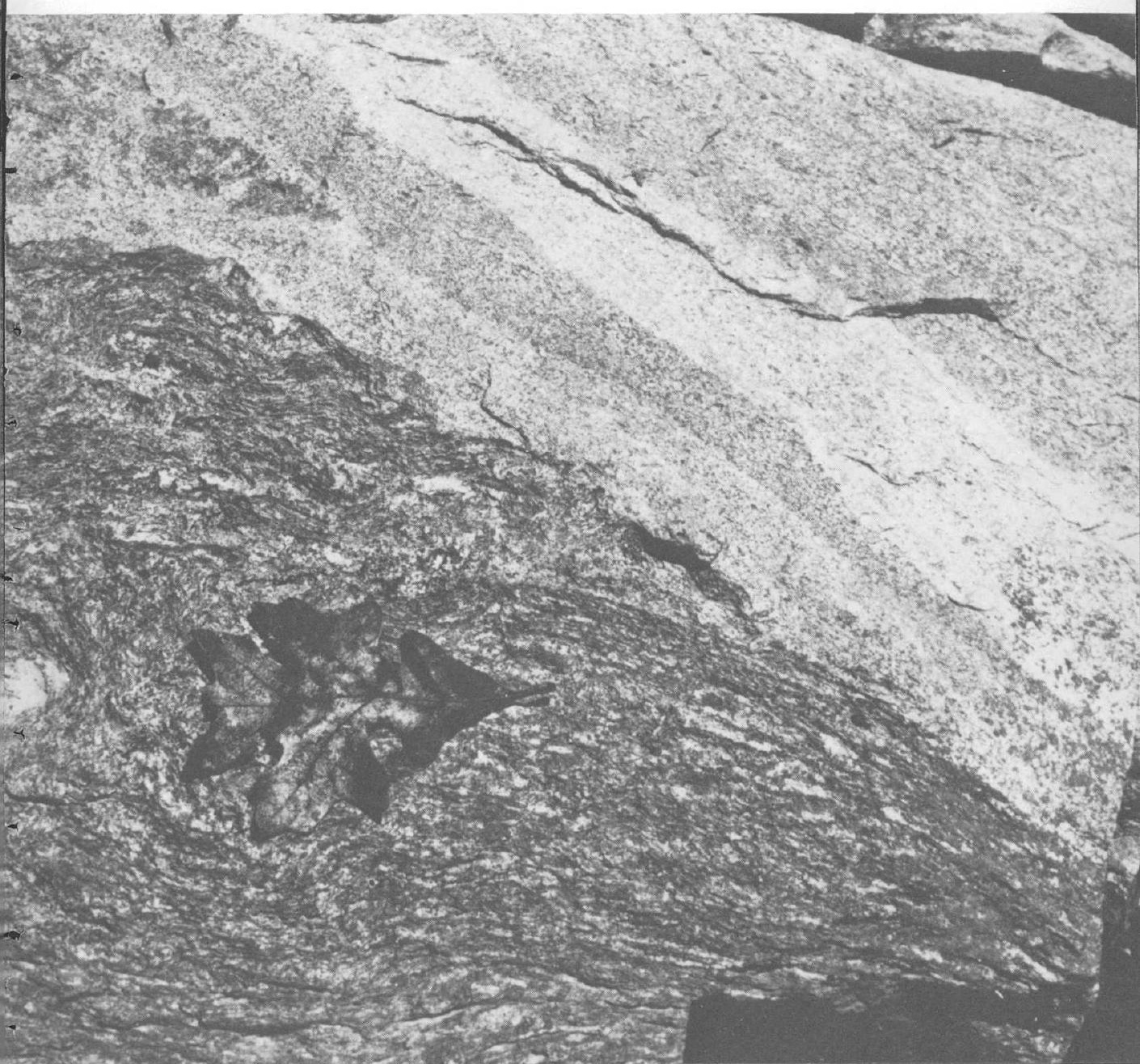


Continue upstream along trail following road. Notice thick saprolite exposed in face of old quarry on right.

4.04 Trail junction 10 meters beyond where small stream crosses road. Turn right on well-beaten but unmarked trail that leads west up a tributary valley.

4.27 Road junction. Turn left on gravel road.

4.44 Trail junction. Blue-blazed trail turns right to Cowhoof Rock. Continue straight ahead on road.

4.47 Trail descends gently into saddle in ridge. Close examination of the woods in this area reveals small bits of charcoal, charred tree bases, and logs. Many of the small trees and shrubs appear dead. The fire, however, killed only the tops and regrowth appeared as sprouts. This fire occurred during the summer in the mid-1960's. Farther along on the slope on the left is a common, evergreen ground cover, tree clubmoss (Lycopodium obscurum).

4.65 Many fragments of white quartz derived from another vein like the one above Cowhoof Rock.

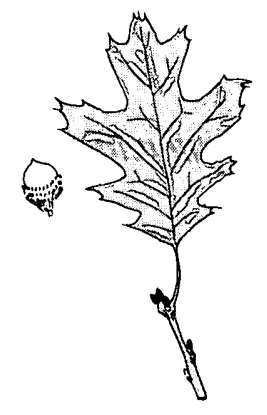

black oak

4.97 Junction with old carriage road. This road was a main access to Great Falls around the turn of the century. It was abandoned in 1935 when the electric trolley line was removed and Old Dominion Drive was opened to auto traffic. The road is cut 3 to 4 meters deep into schist saprolite. Turn right on road. On the slopes beside the road are light-gray, smooth-barked American beech and abundant mountain laurel.

5.46 Road crosses small stream that drains a swamp. This swamp, once a channel of the river, contains peat deposits at least 9,500 years old. The peat rests on rounded pebbles and boulders, deposited by the river, and the peat must have accumulated after the river abandoned this channel. The surface shortly before 9,500 years ago probably looked much like the rocky surface along the river at Chain Bridge, which is swept by floodwaters several times a year. 
Vegetation in the swamp is markedly different from any other vegetation in the Park. Trees are red maple, black tupelo, and pin and willow oaks. Shrubs are sweet pepper-bush; swamp azalea with its white, sticky flowers; poison sumac; common elder; alder; and the ubiquitous greenbrier. Skunk cabbage is common along with lizard's tail. Skunk cabbage is the first plant to bloom in the spring. Flowers appear as early as January or February. The large broad green leaves persist into early summer. When broken, they vield a strong skunk odor.

5.53 Main road bends left; side road branches right. Follow side road 30 meters.

5.56 Cross gravel road leading up out of old quarry and take well-beaten horse trail straight ahead. Ten meters up horse trail is juction with unmarked but wellbeaten foot trail. Continue straight ahead (up hill) on horse trail. You are climbing Glade Hill, which was an island when the river flowed through the 9,500-yearold channel now occupied by the swamp.

The forest on Clade Hill is typical of the uplands. White, black, scarlet, and southern red oaks grow with mockernut hickory, tuliptree, and Virginia pine. Scattered shortleaf pines also grow in the upland woods.

Notice the deep gullies that run parallel to the trail. The trail here follows part of the old road to Matildaville. Like many heavily traveled dirt roads in the Piedmont, this one was subject to severe erosion. Water running down ruts left by wagon wheels eroded gullies in the deep clay soil. When the ruts became too deep, it was easier to move the road to one side than to repair the gullies. In some places this happened several times, leaving a series of parallel gullies.

5.69 Stop 9. AN ANCIENT CRAVEL DEPOSIT. The ground here is littered with gravel and large rounded. boulders, part of a river deposit even more ancient than those along the trail on the bedrock terrace below. This deposit lies almost 40 meters above the present level of the river and must have been 
deposited during a very early stage of the cutting of the valley, perhaps 2 to 3 million years ago.

Follow trail north (upstream).

5.75 Trail junction. Well-beaten side trail to right leads steeply downhill about 100 meters to join blue-blazed trail. Continue straight ahead.

Deep gullies crossing trail were probably caused by drainage from old field, now completely overgrown, which once occupied top of Glade Hill to left. This is well shown on the terrain model on display at the Visitor's Center Museum.

5.85 The area of this field is marked by a wire fence embedded in tree trunks and by the presence of Virginia pine. The pines are dying and falling, thus permitting the hardwood trees to grow more rapidly. In and along the gullies, yellow poplar, a valuable timber tree, is predominant. This species is common in places where soil was severely eroded in the past.

6.21 Trail junction. Turn right about 20 meters. Chimney and ruins of buildings at Matildaville. The town, perhaps one of the first subdivisions in the area, was established in 1790 and leased to "Light Horse" Harry Lee in 1793. It included a sawmill, forge, gristmill, store, and storage buildings and provided lodging and services for the canal traffic. The forest from near the base of the hill to the Patowmack Canal is typical of areas that had heavy land use. Black locust with short stout spines, elm, and boxelder are common. The tree bristling with many-branched thorns is honeylocust, found only here. Many cultivated plants such as daffodils, day lilies, privet, and others indicate human activity. At Matildaville, ruins follow right fork of trail about 15 meters.

6.27 Junction with trail along old Patowmack Canal. Turn left.

6.36 Trail junction. Turn right across footbridge, then left.

6.49 Trail junction. Continue straight ahead.

6.96 Visitors Center. 


\section{Trail log-Great Falls, Maryland}

This walking tour is designed to acquaint you with the important geological, botanical, and ecological features that can be seen from the Park trails. Part of the route is over a rough trail and requires some scrambling over rock ledges, so wear suitable clothes and sturdy hiking shoes. Time required for the full trip is 3 to 4 hours, total distance 5.6 kilometers, but the trip can be cut short at several points. The first three stops are near the $C$ and $O$ Canal towpath and can be visited in about an hour with an easy round-trip walk of about 1.8 kilometers.

\section{Kilometers}

0.00 Leave Great Falls Tavern Visitor Center; cross $C$ and $O$ Canal. The low dam across the river diverts about 9,500 liters of water per second into an underground aqueduct which empties into Dalecarlia Reservoir 14 kilometers away for treatment and distribution to the District of Columbia and nearby suburbs. Turn left . (downstream) on towpath.

SHRUBS AND SMALL TREES

The towpath here is about 4 meters higher than the water level above the dam. The elevation of the towpath is about 52 meters above sea level. On your right is a narrow channel of the Potomac River that separates the Maryland shore from Olmsted Island. The main part of Great Falls is out of view about 0.7 kilometers to the west.

To the right (west) of the towpath and down to water's edge are many small trees that have been overturned by floods. Notice how the vertical stems have sprouted from the prostrate trunks. Sprouting occurred during the first growing season after the flood. To determine the year of the floods, we can core a sprout at its base and count the rings. Most of these trees were damaged during the 1936 flood; the smaller ones, in 1972. These sprouts look like branches but are different. Branches originate from buds on year-old twigs, so a branch is always one year younger than the larger branch from which it grows. Sprouts grow from dormant buds under the bark of trunks, so the sprout can be many years younger than the trunk.

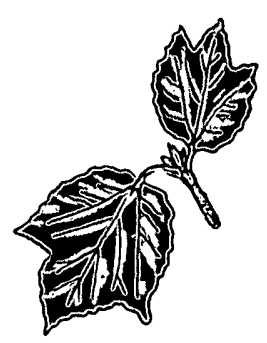

maple-leaf viburnum 


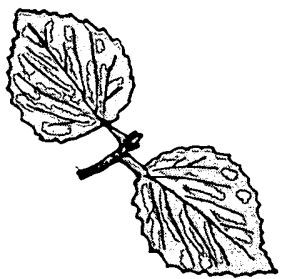

southern arrowroot
Four hundred meters from the Tavern, turn right on short trail leading a few meters west towards remains of old trail bridge.

0.40 Stop 1. METACRAYWACKE. In this area are good outcrops of metagraywacke, the resistant rock that has impeded the downcutting of the river and caused Great Falls. The material that formed this rock was originally a mixture of mud and sand deposited on the sea floor. It has subsequently been altered (metamorphosed) by heat and pressure to produce the tough metamorphic rock you see here. The conspicuous layers 10 centimeters to 1 meter thick were originally nearly horizontal beds but are now tilted to nearly vertical and trend approximately north-south. In several places especially on the south (downstream) side of the outcrop, beds in the metagraywacke display conspicuous folds. On the north (upstream) side of the large outcrop that is circled by the trail, these layers are especially well displayed. In some places, original sand grains 2 to 4 millimeters in diameter are visible in the metagraywacke. Notice that in each layer the grains become progressively finer to the east. There is then a sharp discontinuity and another zone of coarse sand grains at the base of the next layer.

The gradation from coarse to fine sand in each individual layer is called graded bedding. It is characteristic of sedimentary deposits laid down by underwater "avalanches" of sand and mud. As the avalanche comes to rest, the largest sand grains stop first and the finer sand, silt, and mud gradually settle out of the water in order of decreasing size. If the layers are steeply tilted by later deformation, as in this outcrop, the graded bedding makes it possible to determine which are the tops and which are the bottoms of the beds. In this outcrop, the tops of the beds are toward the east, and the older beds are, therefore, on the west. The many knots and thin veins of white quartz represent material that was dissolved by hot solutions moving through the rock during metamorphism and deposited in open cracks or local areas of low pressure. Notice how the quartz stands out from 


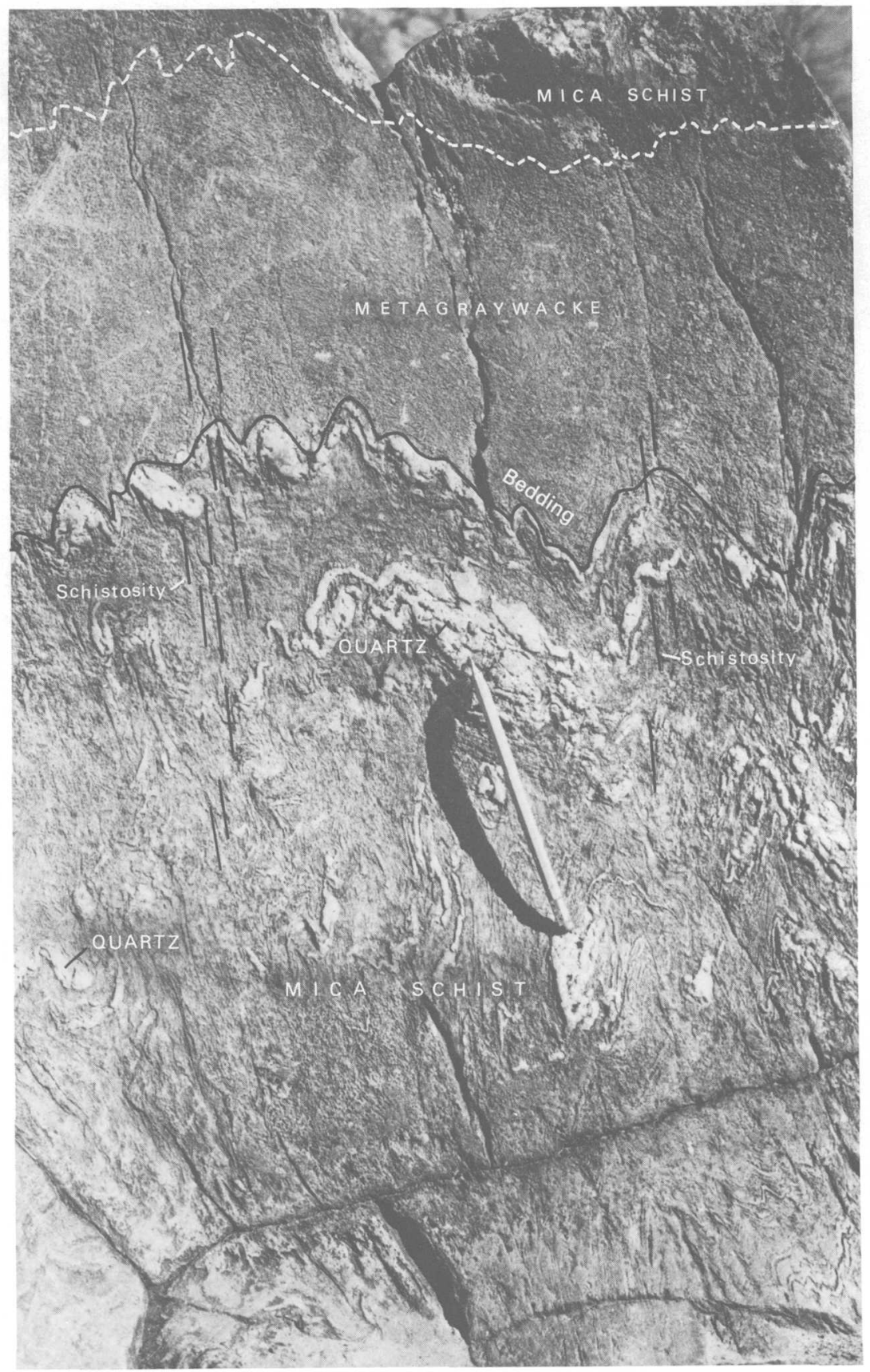

Metagraywacke outcrop at Stop 1 showing graded beds. Tops of the beds are to the east (left). 
the surface of the outcrop, in some places by as much as a centimeter. The surface of this outcrop was once smoothed and polished by the river, but it has been roughened and pitted by weathering. The quartz, being more resistant to chemical attack than the enclosing rock, has been etched into relief. This suggests that the outcrop is no longer polished by the river except during the highest floods.

Most of the trees here are typical of the bedrock terrace surface farther downriver on Bear Island. They are red, chestnut, and post oaks and pignut hickory. Fringe tree, a small tree that bears conspicuous sprays of pale yellow-green flowers in the spring, is common.

Behind you, toward the Tavern, is a channel containing much debris deposited by floodwaters. Trees there are American elm and a few slippery elms, which can be easily distinguished from each other only by their distinct seed. Others are sycamore with its white bark, ash, and black locust. These, as well as a few other tree species, are common on flood plains and are rare on uplands.

Return to the towpath, turn right, and continue downstream.

0.70 Stop 2. ROCKY ISLANDS CHANNEL. The towpath passes high above an intermittent river channel encircling Rocky Islands. Nearly dry in the low-water stages of summer and fall, this channel is often filled to a depth of 10 to 12 meters by winter and spring floods. The towpath here is at an elevation of about 41 meters; you have descended about 10 meters since leaving the Tavern. Notice that the river, which was about 4 meters below the towpath at the Tavern, is now nearly 17 meters below the towpath. This gives you some idea of the drop at Great Falls. The upper surface of the rocky outcrops visible here is at almost exactly the same level as the flood plain of the river above Great Falls.

This surface marks the river bed prior to the cutting of the gorge and the establishment of Creat Falls in its 


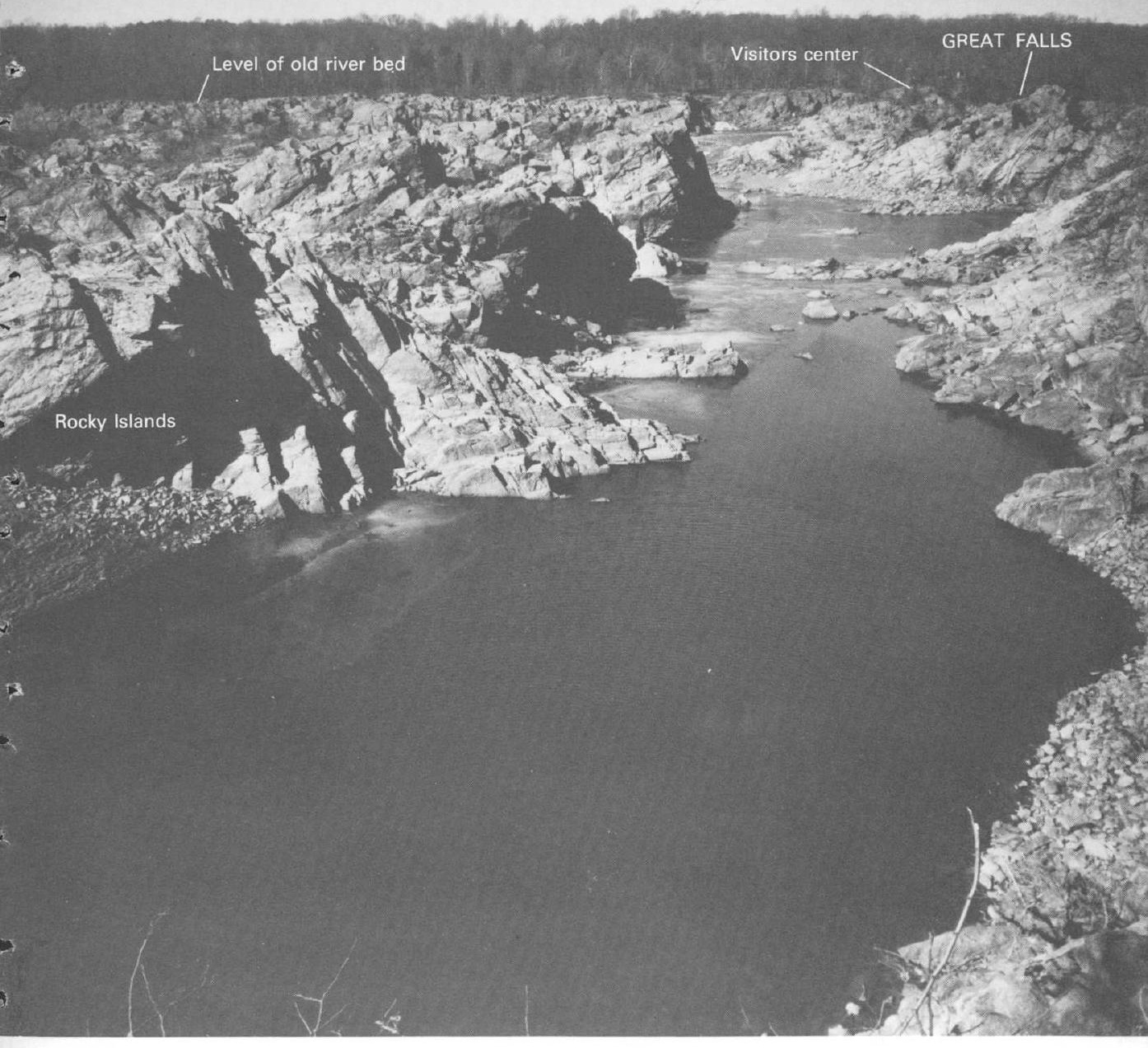

View of Rocky Islands Channel from Stop 2.

present position. The steep rock faces that slope 50 to 70 degrees to your right (north) are joints in the bedrock caused by relief of pressure as the rocks were uplifted and exposed during erosion. A zone of closely spaced joints provided a zone of weakness along which the river worked to cut the channel that extends westward from this point. This zone is indicated by J-J' on the block diagrams. The steeply sloping rock faces nearly at right angles to these joints formed by splitting of the rock parallel to metagraywacke beds.

Notice the small shrubs growing in rocks at the bottom of the channel. These are sycamore, river birch, 
and ash that normally grow to be large trees, but here they are kept small by the frequent battering of flood torrents.

The evergreen trees on the islands are Virginia pine and eastern red cedar, typical of the bedrock surface. Also present are red, post, and chestnut oaks, and pignut hickory. Many of the trees on the island were battered by the flood following Hurricane Agnes in 1972. Water covered the towpath to a depth of $\mathbf{1 . 5}$ meters where you are standing.

The moss halfway down the cliffs (Crimmia laevigata) is green when wet and black when dry. Here it grows only on the cliffs at the level that floods reach about every 2 years. In the Washington area it is found only on rocky cliffs between Creat Falls and Chain Bridge, but it is widespread in the Appalachian Mountains. Continue south (downstream) along towpath.

chinquapin

0.84 Trail junction about 20 meters before towpath reaches stoplock (where wooden steps lead up embankment to bridge across canal); follow Billy Goat Trail (marked by blue paint blazes) to right (southwest). Along the trail and to your right are many bent trees that were felled by the 1936 flood, which was 3 to 4 meters deep here.

The prominent levee to the left of the trail was designed to divert floodwaters from the canal bed and return them to the main channel of the river.

0.91 Stop 3. A FLOOD FELLED TREE. About 65 meters from the towpath is a nearly horizontal tree that was felled by a flood similar to that which felled the trees at Stop 1. The age of the nearly vertical sprout at the end of the inclined trunk tells us that the flood occurred in 1936. The maximum known flood on the Potomac River was on March 19th of that year.

The rounded outcrop about 4 meters east of the trail is thinly layered metagraywacke with many small upright folds. Veinlets of white quartz as much as half a centimeter thick follow the beds around the fold 
noses. Some of the quartz veinlets have been etched into relief of as much as 5 millimeters since this outcrop was smoothed by the river.

Beyond the flood-felled tree is the ubiquitous and troublesome Japanese honeysuckle vine that has nearly smothered the wildflowers and shrubs. Honeysuckle was introduced into the United States from eastern Asia to help control soil erosion. The prominent shrub here is spice bush. It is covered with small yellow flowers in early spring and red berries in the fall. A crushed leaf produces a spicy aroma.

This forest is typical of the bedrock terrace. Prominent trees are post oak, with its almost Maltese crossshaped leaves; red, white, and chestnut oaks; and pignut hickory; along with Virginia pine and eastern red cedar.

Lamprophyre dikes (indicated by white dots) on the Virginia side of the river as seen from Stop 4 on the Maryland side. Outcrop of dike in foreground is indicated by arrow. Location of Stop 3 on the Virginia side is also shown.

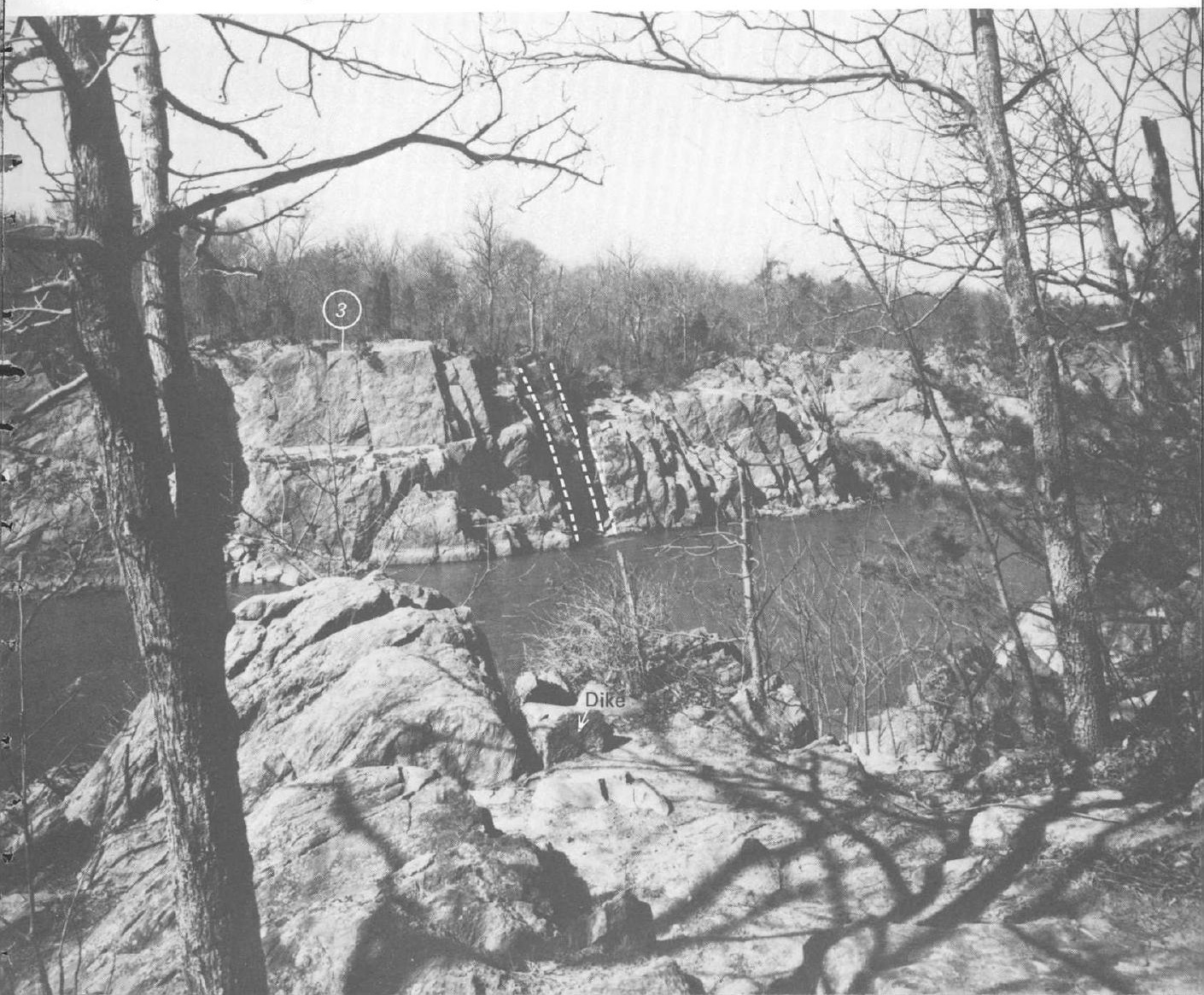




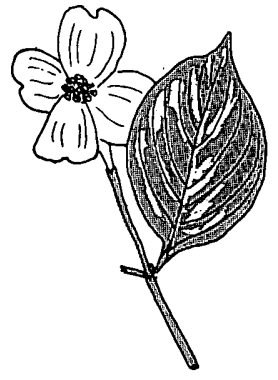

dogwood
Along the trail to the next stop and beyond, you will constantly encounter these trees. Interestingly enough, two common upland oaks, black and southern red, are extremely rare on Bear Island. These species are fairly common, however, on the higher islands down river from Anglers Inn. Small trees that never get as large as the oaks and pines are fringe tree, with its sprays of white, showy flowers in the spring; and blackhaw, with saucer-shaped clusters of white flowers in late spring and blue-black berries in the fall. Possumhaw, a deciduous holly, grows in open rocky areas on Bear Island but is found nowhere else in the Washington area. It grows from here to Florida and in the midwest.

Continue southwest along the Billy Goat Trail past outcrops of metagraywacke similar to those at Stops 1 and 3. Several other flood-felled trees similar to that at Stop 3 are obvious.

1.06 Trail junction. Rough unmarked trail leads right (west) down into lower end of same river channel viewed from Stop 2. The Billy Goat Trail continues left (south). A scramble down the side trail to the bottom of the channel (dry at low water) gives you an opportunity to examine the material in the channel bed. Note that most of the rocks here are large pieces of metagraywacke and schist identical to the rocks that form the walls of the channel. These large pieces, some as large as several meters in diameter, are somewhat smoothed by water. However, their angular shapes and sharp edges indicate that they have not been transported very far by the river. Only the smaller cobbles (less than 30 centimeters) are conspicuously rounded by transport in the river, and only the smaller pebbles and cobbles are composed of rocks that can be identified as having come from any great distance upstream. Evidently even the floodwaters that at times fill this channel to depths of as much as 12 meters do not carry the larger boulders far. Scramble back up to blue-blazed Billy Coat Trail and turn right. Trail passes across bare outcrops of metagraywacke and mica schist, and in about $100 \mathrm{~m}$ descends into a shallow wooded valley about 3 
meters deep. Walk west in valley about 20 meters to small rock outcrop overlooking river.

1.16 Stop 4. LAMPROPHYRE DIKES. Across the river diagonally upstream, notice a series of nearly vertical clefts in the steep rock wall of the gorge. These clefts mark the outcrop of two 20- to 40-centimeter-thick dikes of lamprophyre, a dark lavalike rock that was injected as a liquid in sheets following the steeply inclined joints in the metagraywacke and schist. The narrow valley here is eroded along the same set of dikes on this side of the river. Just to the right (upstream) of the outcrop of metagraywacke in the center of the valley overlooking the river, the dike rock is exposed. The natural surface is weathered and thickly covered with green lichen, but a few freshly broken pieces can be seen. The rock is dark green and filled with glittering flecks of black mica (biotite). Another dike is exposed about a meter farther upstream. Close examination of the upstream dike shows that the biotite crystals are much larger in the center of the dike than they are near its walls. This is because the molten rock material cooled faster close to the cool rock walls than it did toward the center, thus preventing the growth of larger biotite crystals. The straight walls of the dikes and the chilled margins show that they must have been injected long after the metagraywacke and schist had been folded and metamorphosed. Since the dikes have been dated at about 360 million years, we know that the folding and metamorphism of the enclosing rocks occurred before that time.

Notice that the dikes on the other side of the river are not directly on the projection of the narrow valley, but are about 25 meters upstream from where you would expect to find them. The rocks on the two sides of the river have slid past each other along a fault which lies beneath the river at this point. The straight steep-sided gorge is cut in the crushed and broken rocks along the fault, because they are more easily eroded than the solid rocks on either side. Since the fault offsets the dikes, it must have moved since 360 million years ago. 
The common trees here are pignut hickory with stout twigs and compound leaves and red, post, and chestnct oaks. Shrubs are southern arrow-wood, maple-leaved viburnum, and low blueberry.

Return to Billy Goat Trail, turn right, and continue downstream.

Between Stops 4 and 5 the trail is nearly level and passes in and out of forest typical of the bedrock terrace. In about 400 meters the trail emerges from the woods and weaves over bare rock ribs and knobs to the crest of a rocky ridge near the edge of the gorge.

1.68 Stop 5. POTHOLES. The rock here is mica schist containing many thin streaks and small veins of quartz, most of them parallel to crumpled discontinuous layers that probably represent the remains of thin beds in the original muddy sediment that was metamorphosed to form the schist.

Potholes in schist at Stop 5.
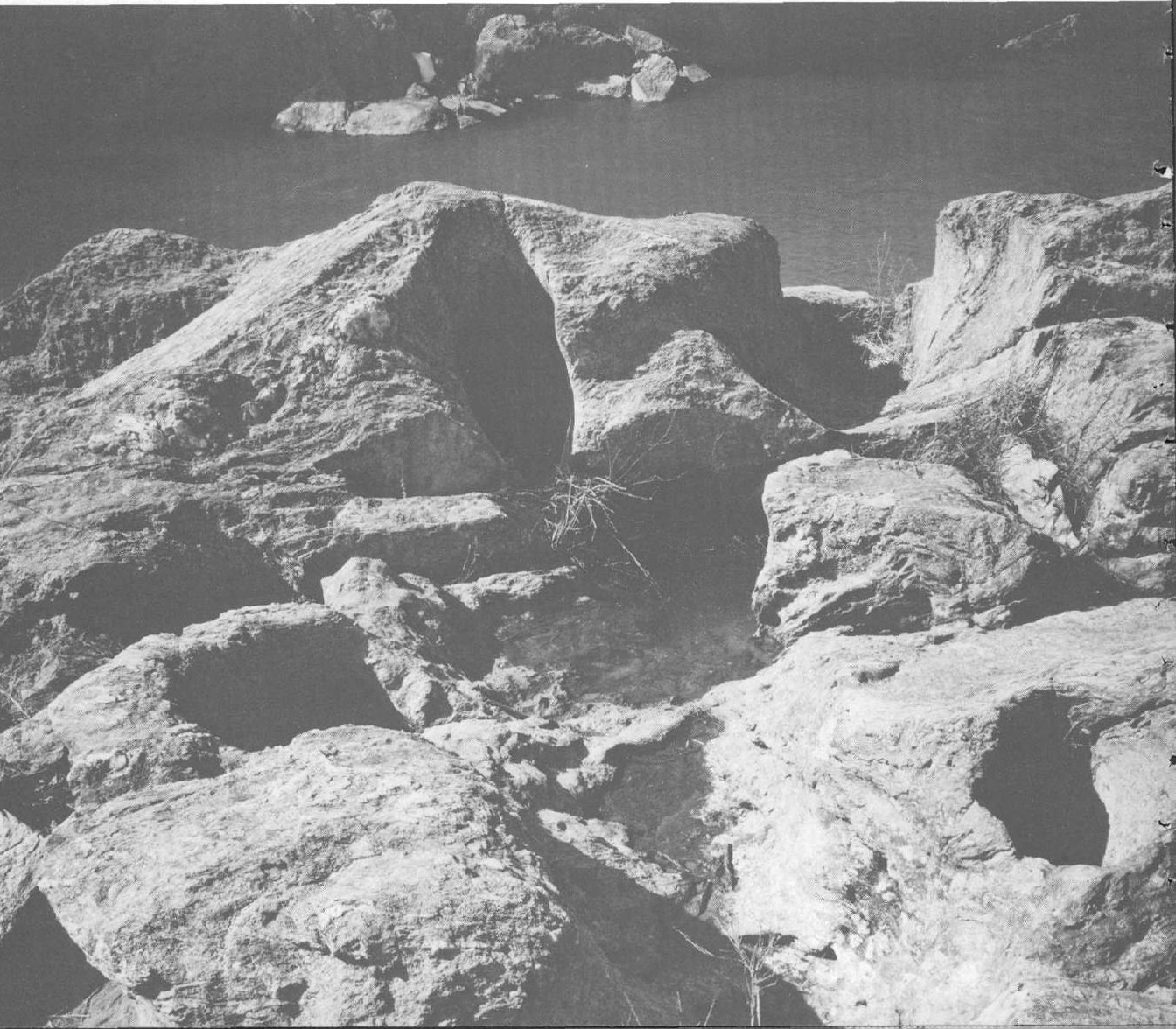


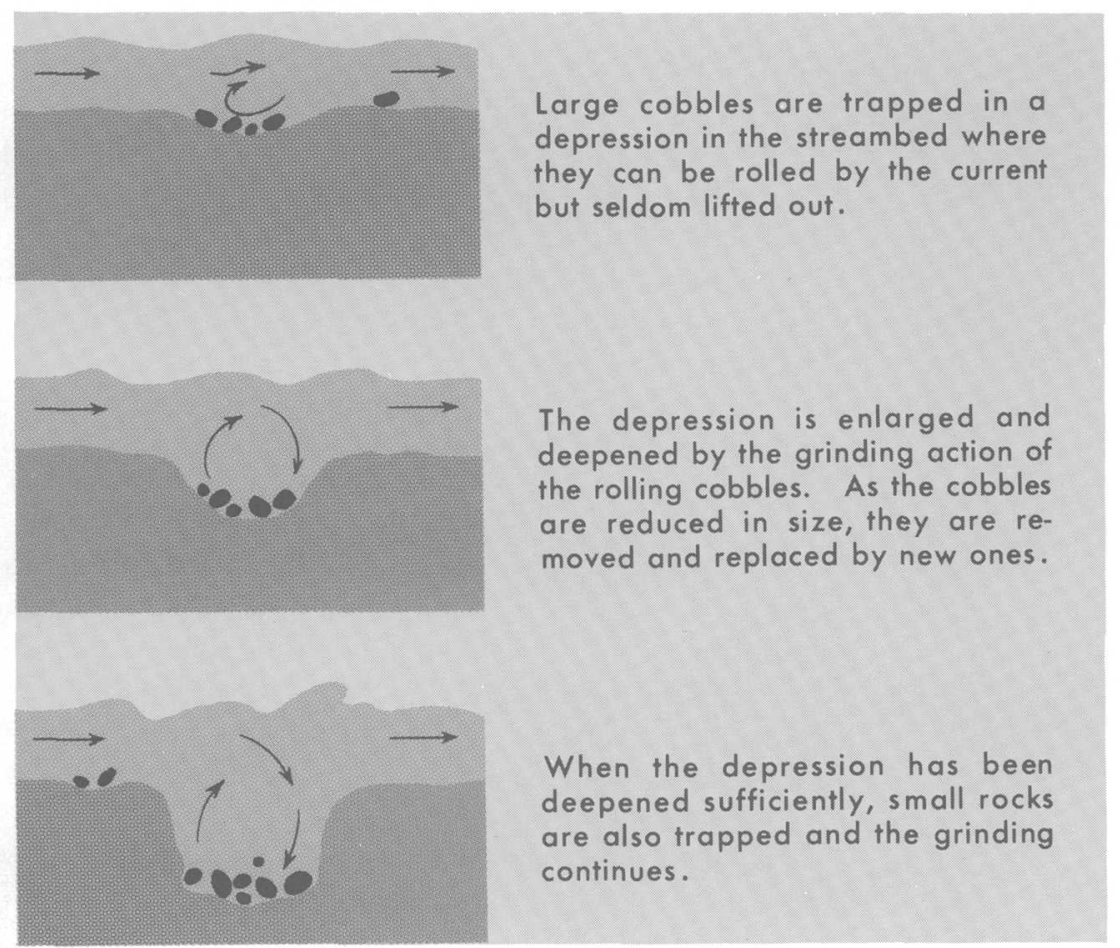

Stages in the cutting of a pothole

This area is part of the bedrock terrace that represents the river bed before the gorge was cut. The same terrace level is marked by the prominent rock bench on the other side of the river. The conspicuous large circular depressions in the rock are potholes that were cut by the grinding action of pebbles and cobbles carried by swirling currents when the river flowed at this level. Trapped in these potholes are large rounded boulders of rocks derived from many kilometers upstream. One pothole contains a boulder of rustybrown diabase that must have been carried from at least 11 kilometers upstream near Blockhouse Point and also boulders of hard white and brown quartzite that came at least from Point of Rocks (55 kilometers) and possibly from Harpers Ferry (70 kilometers) upstream. Other potholes here contain cobbles of Catoctin Greenstone, a green metamorphosed volcanic rock that crops out nowhere closer than Point of Rocks. These far-traveled boulders are much larger than any of those in the dry channel near Stop 3.

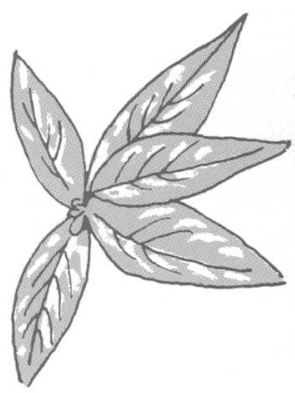

mountain-laurel (evergreen) 
Notice that the rock surfaces of the schist, while still smoothed and rounded in general outline, are in detail much roughened by weathering. This roughening must have taken place after the gorge was cut and the river no longer reached this level except during the very highest floods. Rock surfaces around potholes at the present river level are perfectly smooth and polished by the constant wear of sand and silt carried by the river.

The light-gray lichens plastered to the rocks are Parmelia conspersa, which are common on all exposed rocks at this height above the river. Lichens generally will not grow in cities because they accumulate sulfur from the atmosphere, which eventually kills them.

This stop also provides an excellent view of a remarkably straight and steep-sided gorge cut in the crushed rocks along the fault. On the walls of the gorge, horizontal color bands produced by different blackjack oak species of lichens and by chemical staining reflect different levels of flooding. These are described at Stop 4 of the Virginia trail log.

The trail continues across bare rock ledges for about 120 meters, then descends to the left into the woods. After about another 30 meters it is possible to scramble down to a sandy beach at the river's edge and, at low water, to walk out onto a small rocky peninsula projecting into the river. On this peninsula, verticalstanding beds of metagraywacke, with gradations from coarse sand grains at their bases (on the west) to fine sand at their tops (to the east) are beautifully displayed. Beds range in thickness from 5 to 20 centimeters and are separated by beds of mica schist of about the same thickness. The metagraywacke and schist are cut by one irregular dike of light-colored granite 20 to 30 centimeters thick. In places the granite is composed of very large crystals of feldspar and mica, irregular grains of quartz, and is referred. 
to as pegmatite. Return to Billy Goat Trail and continue right downstream.

1.89 Trail crosses a small stream in a valley eroded along a fault zone. The water in the stream and rocks in the streambed are heavily stained with iron, probably from pyrite (iron sulfide) deposited by solution percolating along the fault zone. The pyrite has been dissolved by the creek as it cuts its way down into the crushed rocks, and the iron reprecipitated as iron oxide.

This mineralized fault zone is one of a series of such zones which extends northward from here for the next 3 to 4 kilometers. It was along these zones that the gold deposits were mined in about half a dozen small gold mines near Great Falls. The fault beneath the river in the gorge is probably one of the same set of faults.

The white-barked sycamores in this valley are growing with ash, elm, and boxelder on fine soil deposited on the flood plain of this small stream by high water. A little-used trail turns left along the east side of the brook and leads 0.3 kilometers to the $\mathrm{C}$ and $\mathrm{O}$ Canal towpath.

Continue across valley and follow trail up cleft in rock slabs.

For about 350 meters the trail winds through the woods among outcrops. of metagraywacke; it then turns to the right and descends toward the river. Stop 6 is near the point where the trail emerges from the woods and descends through a small sandy brushfilled valley to bare rock outcrop near the river.

2.30 Stop 6. ECHO CLIFFS. The high bluffs across the river are Echo Cliffs. Locally they are as much as $\mathbf{4 5}$ meters high.

The central part of the cliffs just downstream from this stop is composed chiefly of metagraywacke similar to that exposed on the small peninsula on this 


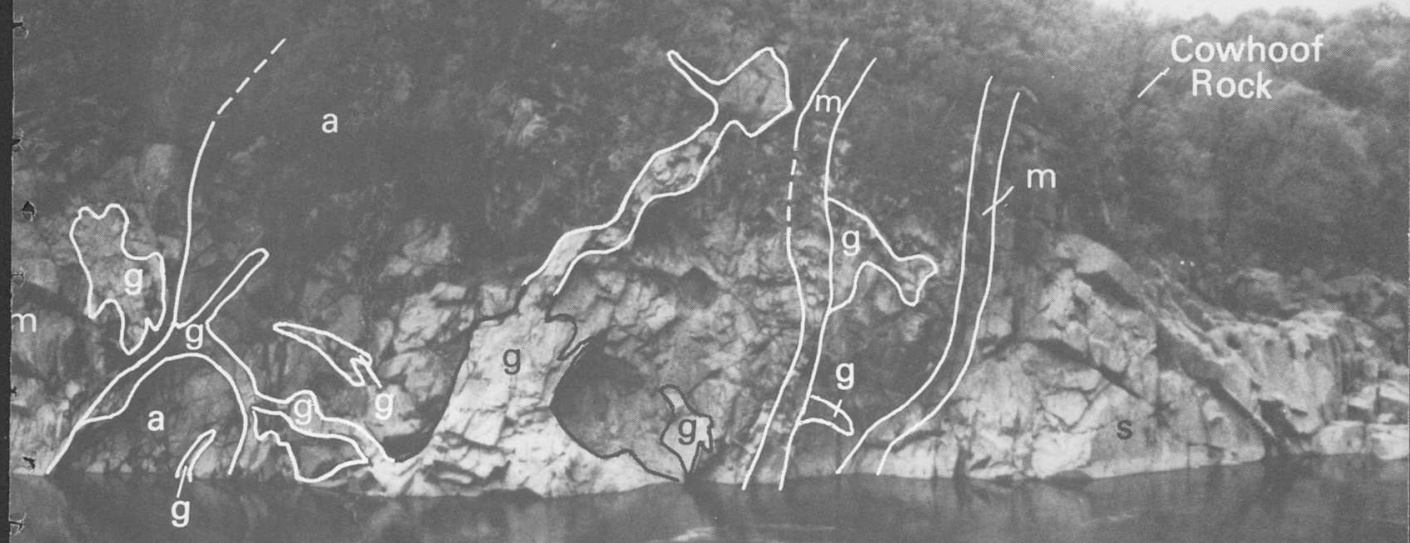

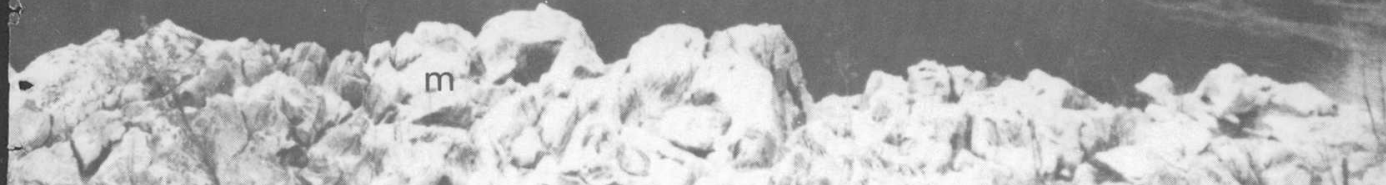

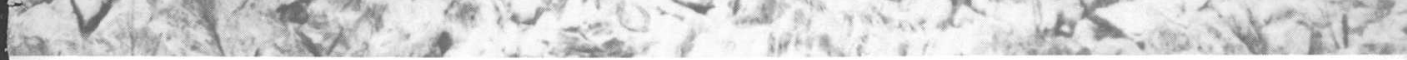

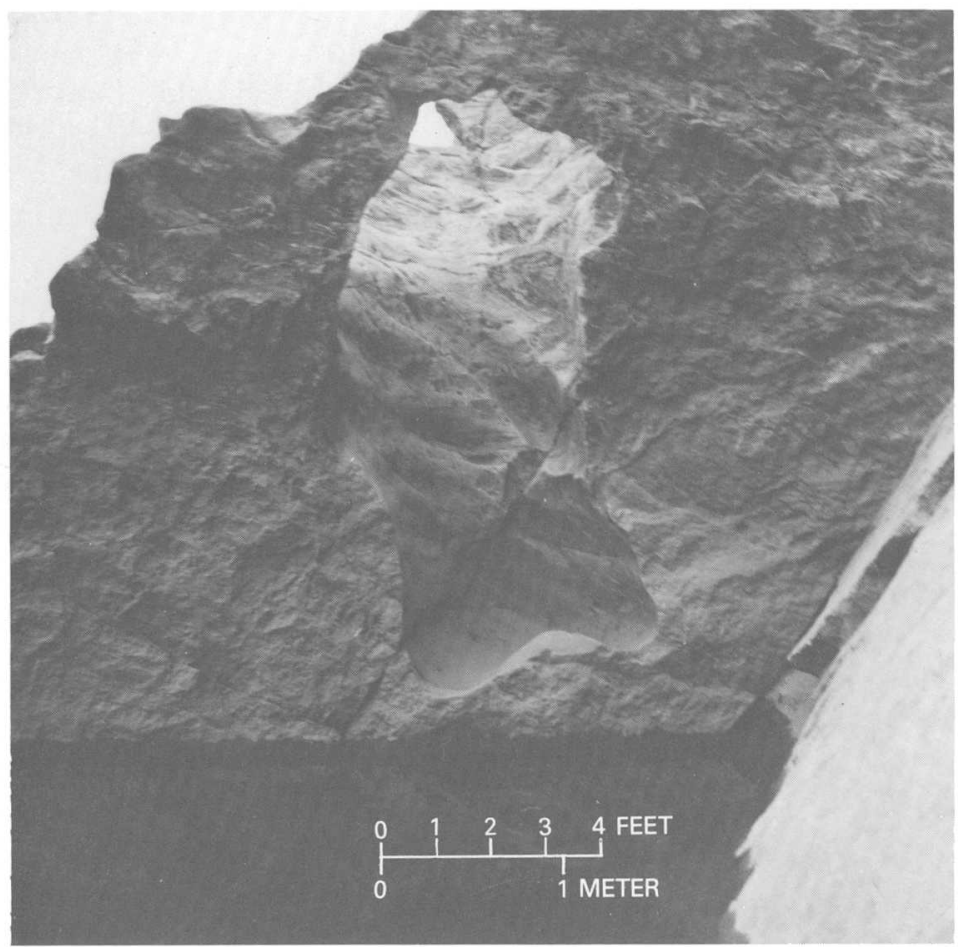




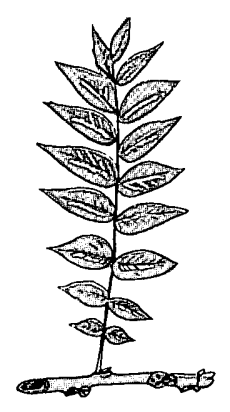

black walnut side of the river just in front of you. The dark green rock in the cliffs farther downstream is amphibolite, an extension of the amphibolite body on which you are standing. The rock at both the upstream and downstream ends of the cliffs is mica schist containing very abundant thin veinlets of quartz and feldspar formed during metamorphism. All of the rocks in the cliff are cut by dikes and irregular bodies of granite, similar to the granite that forms the prominent lightcolored knob behind you. The amphibolite in the cliff is probably all part of a single 20- to 30-meter-thick layer that was injected as a sheet of molten material parallel to the beds of mudstone and sandstone now represented by schist and metagraywacke. Dating of zircon, a rare mineral with a trace of radioactivity, indicates that the molten rock material cooled and crystallized about 550 million years ago. When the sedimentary materials were metamorphosed to form schist and metagraywacke, the basaltlike rock was metamorphosed to form amphibolite. The am-s phibolite layer has been folded along with the enclosing rocks, and so the layer that appears in the upstream part of the cliff is folded down beneath the metagraywacke in the central part and reappears near the downstream end of the cliff. The dikes of granite and pegmatite injected the amphibolite and the enclosing rocks about 470 million years ago after this folding was largely completed.

Two fault zones, one containing a 1-meter-thick quartz vein, are exposed near the downstream end of the cliff. The vein probably connects with the large body of quartz near the river's edge a few meters south of this stop. Notice the enormous potholes near the downstream end of the cliffs.

The outcrops within a few meters of this point afford an opportunity to examine the amphibolite and metagraywacke in some detail. The amphibolite characteristically displays dark-green knots 0.5 to 1 centimeter in diameter. These are clusters of hornblende crystals that have formed during metamorphism, replacing crystals of pyroxene (an iron- 
magnesium-aluminum-silicate) in the original igneous rock. The light-colored mineral between them is feldspar. Notice that the hornblende knots are largest near the center of the large amphibolite body and become finer at both sides. This suggests that the original igneous rock chilled rapidly against the enclosing sediments and crystallized so fast that large pyroxene crystals had no time to form.

Just upstream from the amphibolite, numerous beds of metagraywacke 2 to 20 centimeters thick and a 1.5-meter-thick sheet of amphibolite are interlayered with mica schist. Graded bedding in the metagraywacke indicates that the tops of beds are to the east. These rocks display many of the details of the folding and metamorphism outlined earlier. Most rocks display a prominent alinement of platy minerals (schistosity) generally parallel to the layering; a few contain folds which apparently formed at the same time as the schistosity, because the schistosity in their noses cuts through the layering. Hornblende clusters in the amphibolite are crushed and strung out parallel

Early folds in metagraywacke near Stop 6. Schistosity cuts across bedding in the noses of folds, but everywhere else the two are parallel

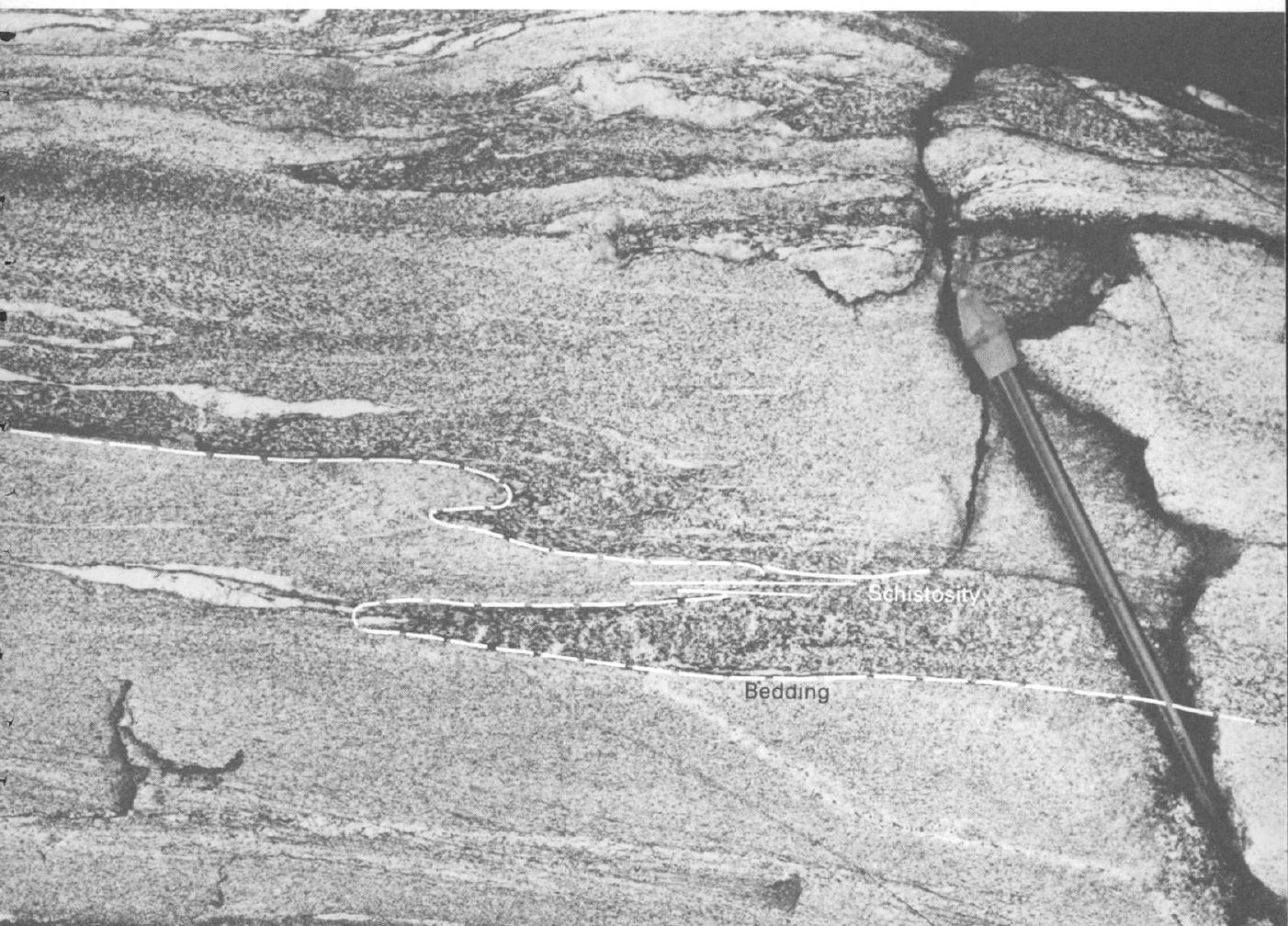




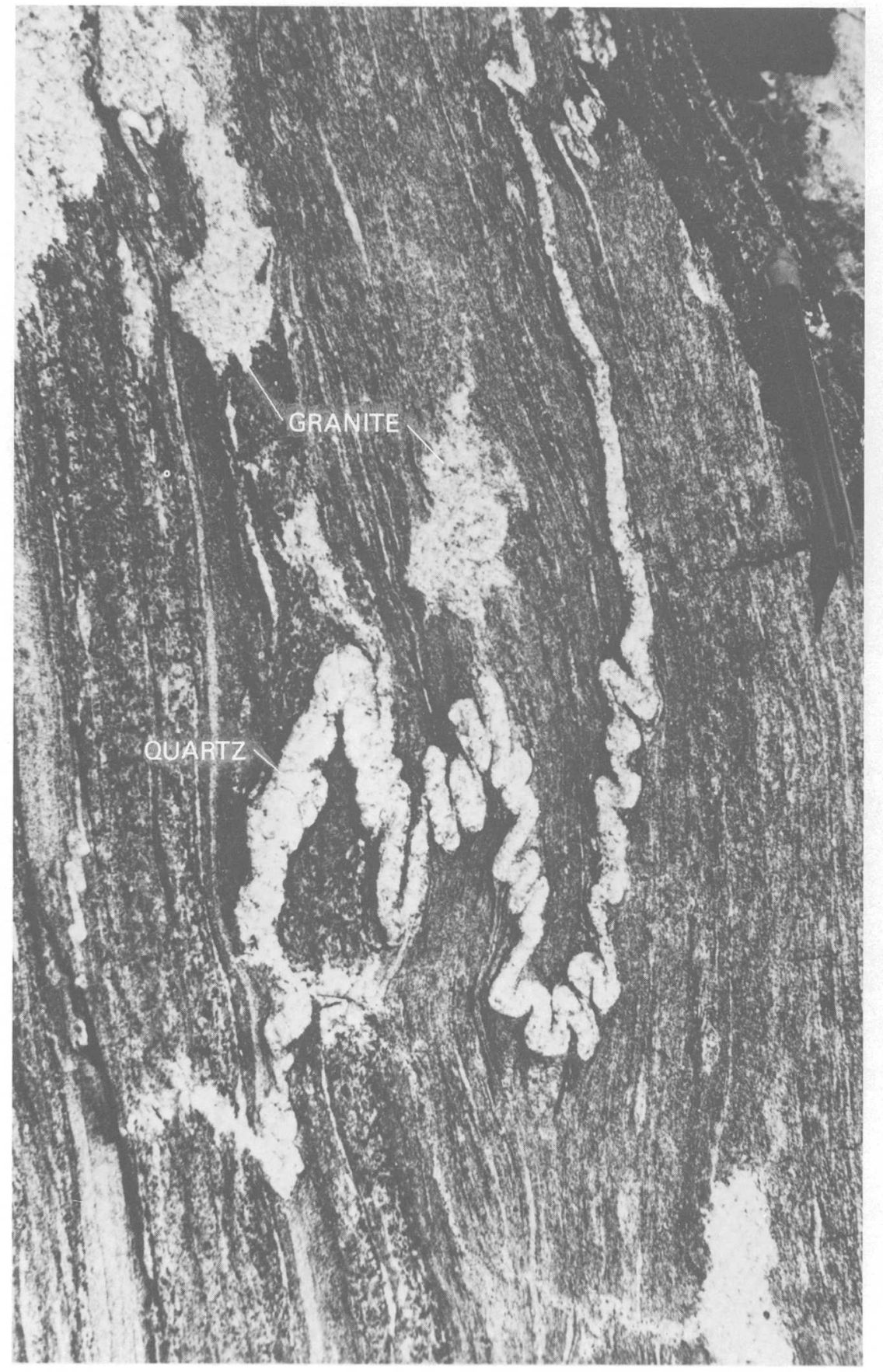


to the schistosity, showing that the amphibolite must have been intruded and metamorphosed before these early folds formed. The large fold exposed in the cliff across the river formed later, because the schistosity is bent around it.

The rocks are cut by many thin veinlets of quartz, most of which are intricately folded and must have formed prior to the early folds and the schistosity. But the small veins and irregular pods of light-colored, coarse-grained granite cut across the schistosity, showing that the granite must have been intruded after the folding. Several of the mica schist layers contain elongated ( 5 centimeters) crystals of light-colored kyanite; they too must have formed after the early folding, because they clearly pushed the schistosity aside as they grew.

Altered crystals of kyanite in mica schist near Stop 6. The crystals are as much as 5 centimeters long.

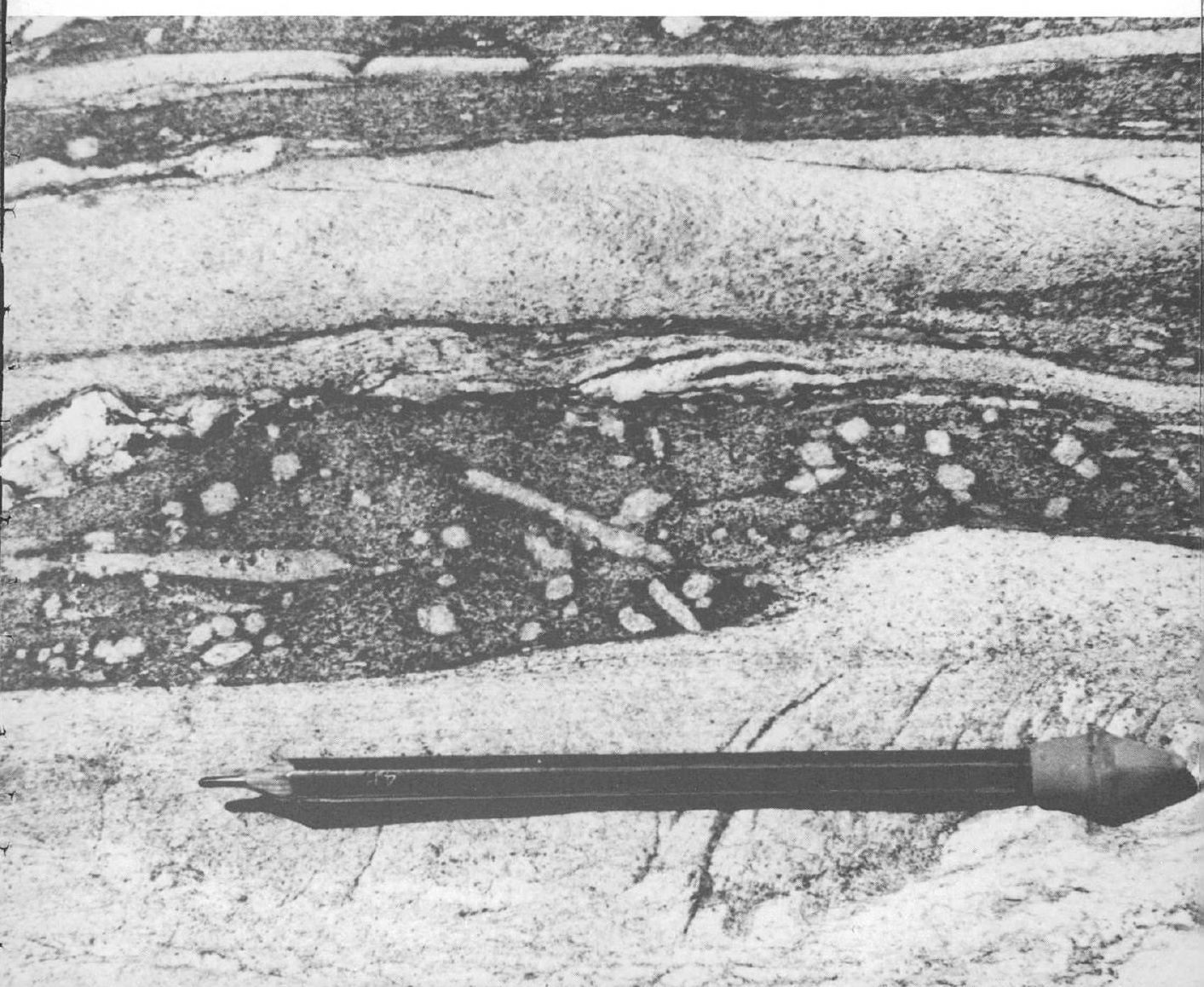


Continue southeast along trail across bare outcrops of thinly layered metagraywacke and schist showing occasional folds and many irregular splotches and streaks due to growth of metamorphic minerals. Small dikes of granite and pegmatite are abundant in this area. In about $\mathbf{8 0}$ meters the trail descends from a rock rib and crosses a sandy beach. It then climbs across another series of rock slabs and skirts to the left around a high rock knob. Stop 7 is in a sandy hollow just east (downstream) of this knob.

2.50 Stop 7. LATE FOLDS. The flat rock slab near the north side of the sandy hollow displays a good example of one of the late folds, a miniature version of the large fold exposed in Echo Cliffs.

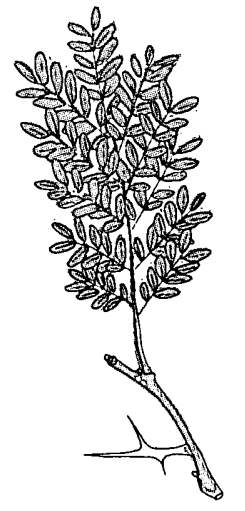

honey locust

The early schistosity, parallel to the metagraywacke layers, is bent around the fold; and a second, weaker schistosity has formed at an angle to the first.

From here the trail descends into a small valley which follows the sinuous form of a folded amphibolite sheet, more easily eroded than the schists and metagraywackes on either side. This fold is another larger scale example of the late folds, like the one at Echo Cliffs.

One of the early folds may be seen about 60 meters farther along the trail where it passes near the edge of a pond. In the rock face about 10 meters to the left of the trail is a metagraywacke bed that is folded back completely on itself. The doubled-back bed has then been refolded as part of the later folding displayed at Stop 7. Across the pond from the trail, sycamore, boxelder, ash, and silver maple trees are growing on fine soil deposited by the river during high water. The trail continues around the north side of the pond, then climbs a rocky slope with metagraywacke outcrops, and passes through a jumble of boulders and outcrops of amphibolite.

2.74 Trail crosses small stream. An unmarked but wellbeaten side trail leads left (north) 290 meters to the $\mathrm{C}$ and O Canal towpath 2.4 kilometers southeast of 


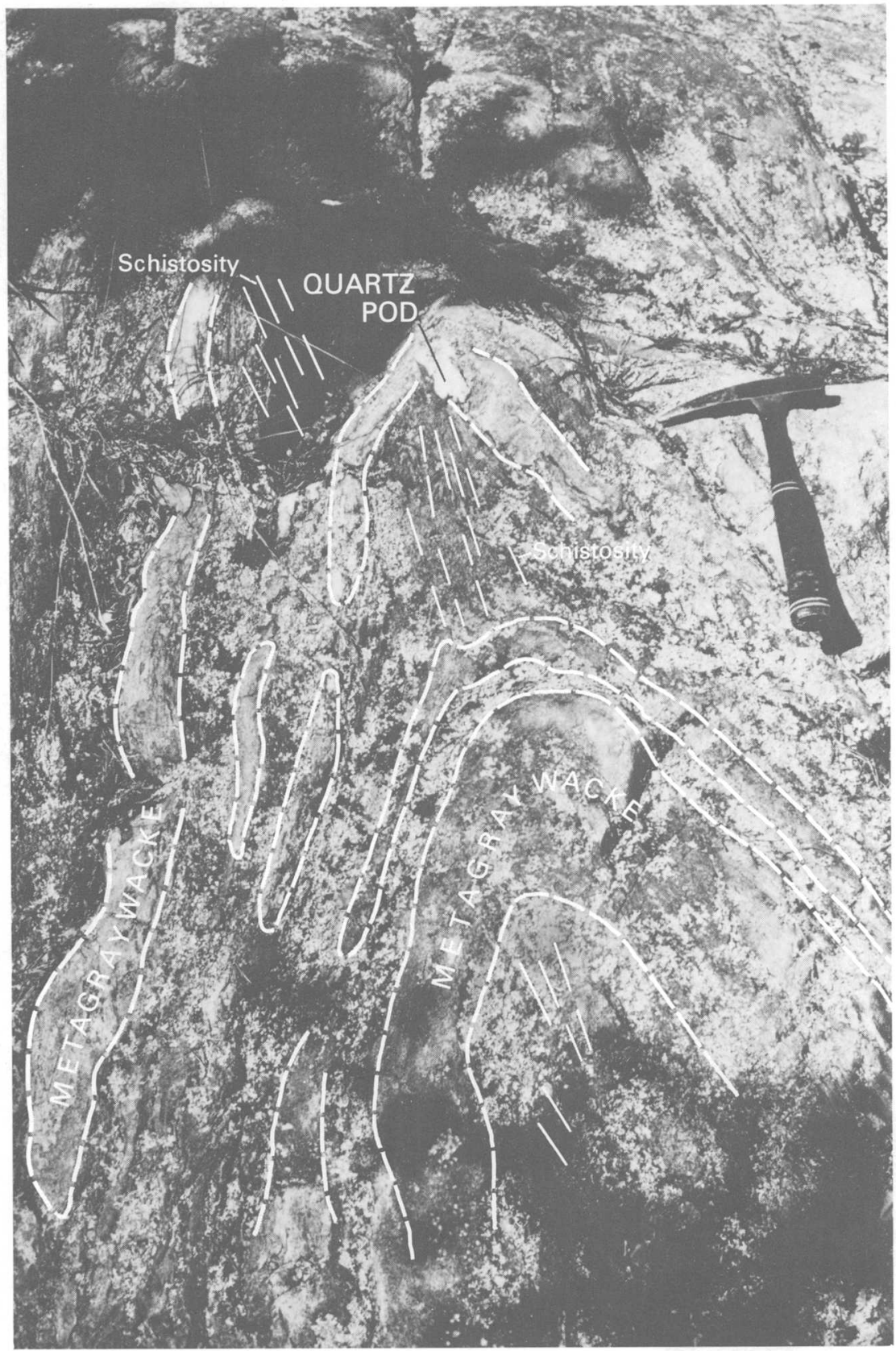

Late fold in interlayered mica schist and metagraywacke at Stop 7. An old schistosity lies parallel to the bedding; the new schistosity, formed during development of this fold, cuts across the bedding in the hinge of the fold. Details are partly obscured by lichen growth (light gray in photograph). 
Great Falls Tavern and 0.85 kilometers west of the parking lot at Anglers Inn. The blue-blazed Billy Goat Trail continues right (south) across a low rocky ridge (chiefly schist and metagraywacke, some granite and pegmatite).

2.82 Trail descends steep rock outcrop into small open valley with scattered outcrops of amphibolite (probably part of separate layer from that exposed in Echo Cliffs and around the pond near Stop 7).

The trail crosses another rib of schist and metagraywacke, then crosses more large blocks of amphibolite, and emerges on an open flat covered with fine soil. To the left is a large outcrop of mica schist.

black locust

Block diagram showing folded amphibolite near Stop 7

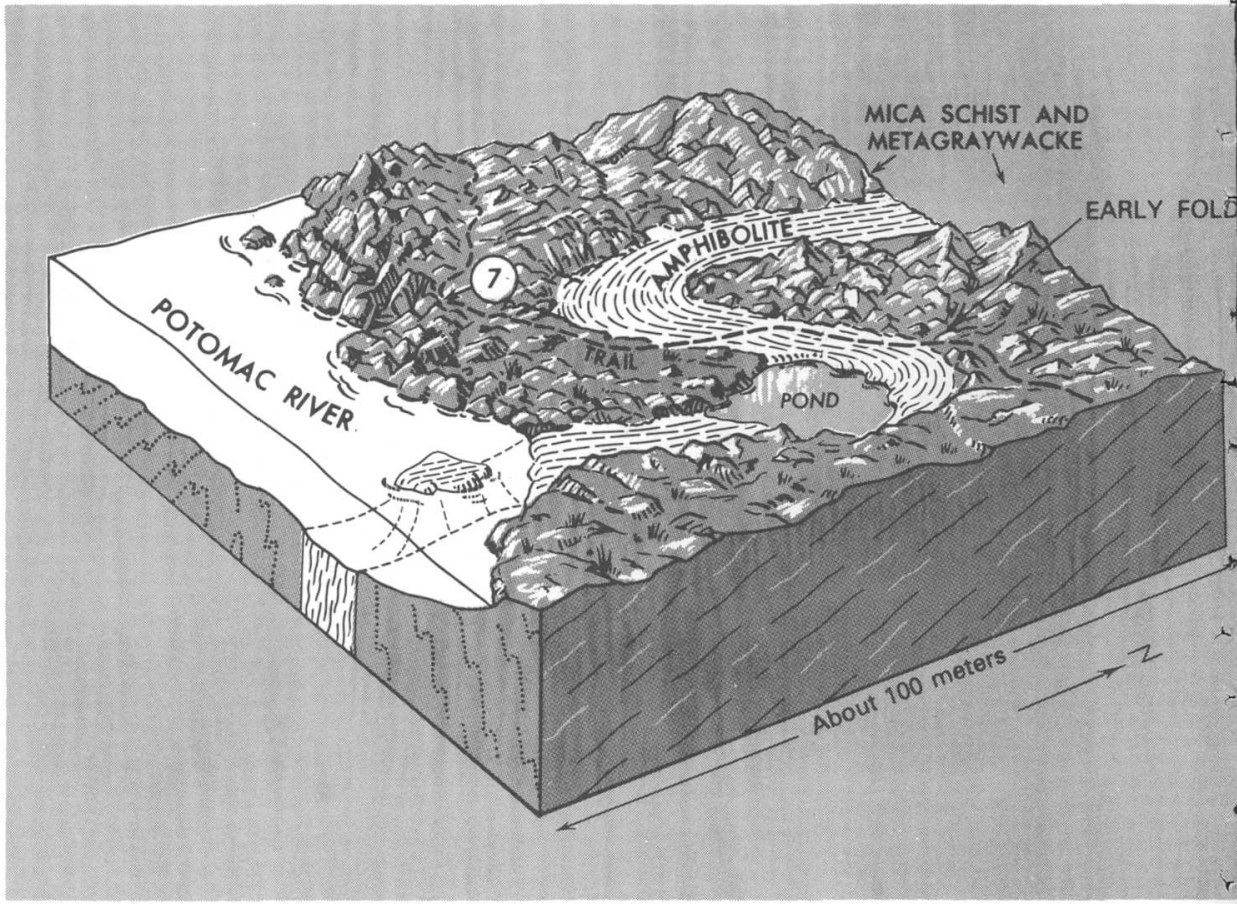



over blocks in the bottom of a small draw to the top of the outcrop. Here is another rare plant-prickly pear cactus.

In this region it grows only on Bear Island, along the coast, and in certain areas in the Shenandoah Valley. The presence of cactus here seems to be in contradiction with the nearby bogs where red maple and black tupelo thrive. Black tupelo is a tree with smooth gray bark and nearly horizontal branches. Red maple also has light-gray bark, but the twigs, buds, and leaves grow opposite each other. These two are the most common trees in swamps on Bear Island.

The contrast is due to the virtual absence of soil on much of the irregular surface of the bedrock terrace on Bear Island. The deep clayey soils formed by chemical weathering of the underlying rocks in adjacent parts of the Piedmont upland have not yet had time to form on the recently river-scoured surface of the bedrock terrace. The only soils are sand and silt deposited by recent floods in low hollows and in nooks and crannies among the rocks. Rainwater runs almost immediately off the dry rock ridges and collects in the undrained potholes and abandoned channels to form ponds and swamps.

Return to Billy Goat Trail and continue downstream. In about 60 meters the trail rounds a rocky ridge and turns north.

3.06 Trail dips into valley containing elongated pond on left. This part of the trail is impassable during floods because water flows from the river northward. Note the flood debris that litters the valley bottom and that is caught on the south sides of shrubs and tree trunks. Many trunks lean to the north, showing that high water flows from the river to your right and sweeps around the hill in front of you.

Trail climbs steeply over 15-meter hill. It then descends into another deep valley, actually a continuation of the one you just crossed. Note here that 


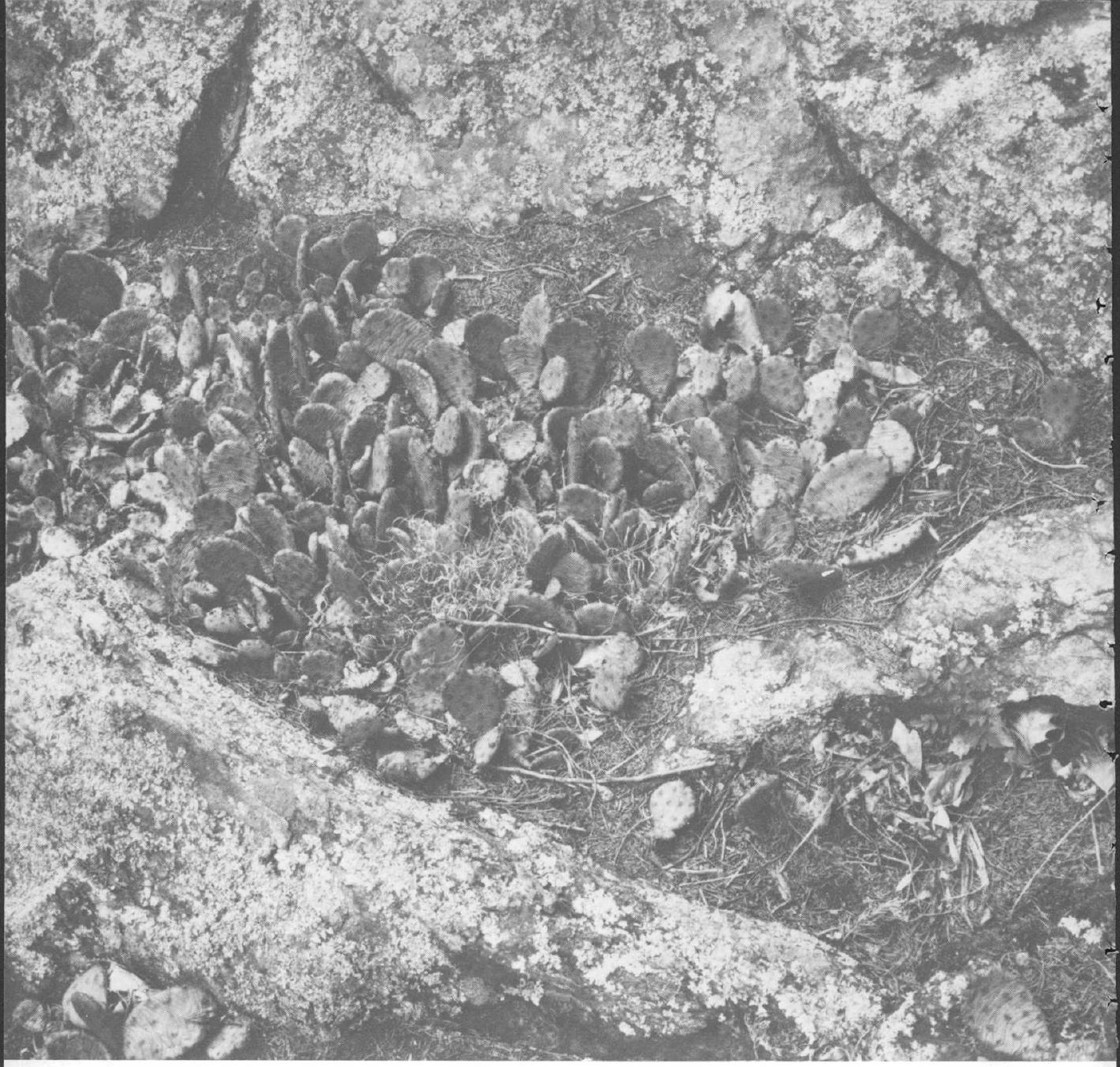

Prickly pear cactus at Stop 8.

flood debris on shrubs and trees and leaning trunks show that high water flowed from your left to the river on your right.

Trail crosses the valley and follows gulley to top of rocky plateau. Just before descending again, it passes to the right of a low ledge extending diagonally away to the left.

3.32 Stop 9. ANDALUSITE. On top of this ledge a few meters west of the trail, the schist contains abundant 
stubby, gray, 1- to 2-centimeter-long crystals of andalusite, a metamorphic mineral with the chemical formula $\mathrm{Al}_{2} \mathrm{SiO}_{5}$. Andalusite is fairly common in the schist at this end of Bear Island; near Stop 6, kyanite, another mineral with the same chemical composition, is found. Microscopic examination shows that both the kyanite and andalusite are partly changed to sillimanite, a third form of $\mathrm{Al}_{2} \mathrm{SiO}_{5}$. Laboratory studies show that these three minerals with the same composition can form together only at temperatures of about $650^{\circ} \mathrm{C}$ and pressures of about 5.5 kilobars, corresponding to depths of 20 to 30 kilometers. Since all three minerals occur together within a very small area, we conclude that metamorphism of the rocks now exposed here on Bear Island took place at approximately that temperature and depth.

Trail descends steeply into another valley, follows river bank a few meters, then climbs back to level surface of bedrock terrace.

3.55 Billy Coat Trail emerges on $\mathrm{C}$ and $\mathrm{O}$ Canal towpath. Turn left 2.08 kilometers to Creat Falls Tavern or right 0.65 kilometers to causeway across canal leading to parking area at Anglers Inn.

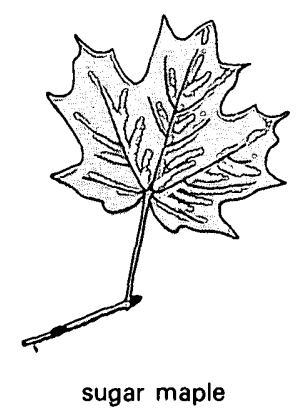




\section{Suggested Reading}

Botanical evidence of floods and flood-plain deposition, by Robert S. Sigafoos: U.S. Geological Survey Professional Paper 485-A, Washington, 1964, $35 \mathrm{p}$.

The geology of Howard and Montgomery Counties, by Ernst Cloos, C. A. Hopson, G. W. Fisher, and Emery T. Cleaves: Maryland Ceological Survey, Baltimore, 1964, $373 \mathrm{p}$.

Crystalline rocks of the Potomac River Gorge near Washington, D.C., by John C. Reed, Jr., and Janice Jolly: U.S. Ceological Survey Professional Paper 414-H, Washington, 1963, 16 p.

The metamorphosed sedimentary rocks along the Potomac River near Washington, D.C., by Ceorge W. Fisher, in Studies of Appalachian geology-Central and southern: Wiley-Interscience Publishers, New York, 1970, p. 299-316.

The Piedmont crystalline rocks at Bear Island, Potomac River Maryland, by George W. Fisher: Maryland Geological Survey Guidebook No. 4, $32 \mathrm{p}$.

Gold veins near Great Falls, Maryland by John C. Reed, Jr.; and John C. Reed: U.S. Geological Survey Bulletin 1286, Washington, 1970, 22 p.

The District of Columbia, its rocks and their geologic history, by Martha S. Carr: U.S. Geological Survey Bulletin 967. Washington, 1950, $59 \mathrm{p}$.

Geology and ground-water resources of Washington, D.C., and vicinity, by Paul M. Johnston, with a section on Chemical quality of the water, by D. E. Weaver and Leonard Siu: U.S. Geological Survey WaterSupply Paper 1776, Washington, 1964, 97 p.

The Fairfax family in 'Fairfax County, by Kenton Kilmer and Donald Sweig: Fairfax Co. Office of Comprehensive Planning, Fairfax Co., Va., 1975, $119 \mathrm{p}$. 


\section{Acknowledgments}

The original edition was prepared under the auspices of the Ceological Society of Washington. C. B. Hunt of the Johns Hopkins University; W. L. Newman of the U.S. Geological Survey; and S.W. Schiffman, A.T. Outlaw, and S.Q. Smith of the National Park Service gave valuable advice on format and content. The discussion of vegetation changes in the, past 16,000 years is based on pollen studies by Isabel A. Griffith of Aldie, Va. Kathleen G. Muth and Joseph G. Arth kindly made available unpublished age determinations on mica samples from pegmatite dikes.

Drawings are by J. R. Stacy of the Geological Survey. Photographs on page viii are by the National Park Service; those on pages iii, 2, and 12 are by James Q. Reber of Bethesda, Md.; and those on pages 7, 18, 27, $29,31,33,42,44,45,53,55,58,62,63$, and 72 are by David F. Usher of the U.S. Geological Survey; and those on pages 37 are by Thomas M. Yanosky, also of the U.S. Geological Survey.

\section{Metric-English Conversion}

[The following table gives the factors used to convert metric units to English units.]

\begin{tabular}{lll}
\hline Multiply metric units & by & to obtain English units \\
\hline millimeters & 0.03937 & inches \\
centimeters & 0.39 .37 & inches \\
meters & 3.281 & feet \\
kilometer & 0.6214 & mile \\
hectares & 2.471 & acres \\
liters & 0.2642 & gallons \\
metric ton & 1.102 & ton \\
kilobar & 14.50 & pound-force per square inch \\
Celsius $\left({ }^{\circ} \mathrm{C}\right)$ & 1.8 and +32 & Fahrenheit $\left({ }^{\circ} \mathrm{F}\right)$ \\
& &
\end{tabular}




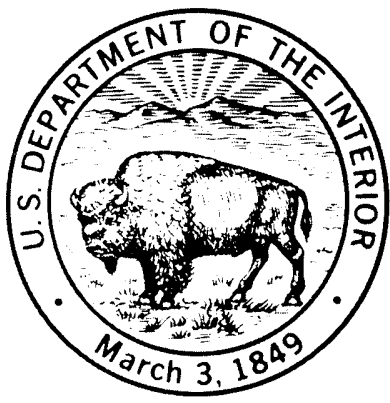

유

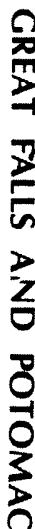

究

I 